Keywords: DWPF, CPC, sludge, SRAT, Sludge Batch 3

Retention: Permanent

\title{
Sludge Batch 3 Simulant Flowsheet Studies: Final Phase SRAT/SME Results
}

\author{
C.C. Herman \\ D.C. Koopman \\ D.R. Best \\ T.K. Snyder \\ M.F. Williams
}

Date: September 30, 2003

Westinghouse Savannah River Company

Savannah River Technology Center Aiken, SC 29808

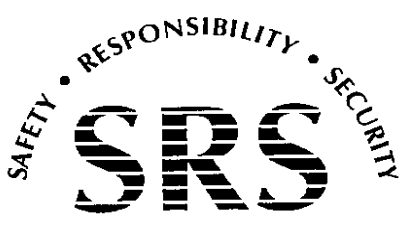

SAVANNAH RIVER SITE

PREPARED FOR THE U.S. DEPARTMENT OF ENERGY UNDER CONTRACT NO. DE-AC09-96SR18500 
This document was prepared in conjunction with work accomplished under Contract No. DE-AC09-96SR18500 with the U. S. Department of Energy.

\section{DISCLAIMER}

This report was prepared as an account of work sponsored by an agency of the United States Government. Neither the United States Government nor any agency thereof, nor any of their employees, makes any warranty, express or implied, or assumes any legal liability or responsibility for the accuracy, completeness, or usefulness of any information, apparatus, product or process disclosed, or represents that its use would not infringe privately owned rights. Reference herein to any specific commercial product, process or service by trade name, trademark, manufacturer, or otherwise does not necessarily constitute or imply its endorsement, recommendation, or favoring by the United States Government or any agency thereof. The views and opinions of authors expressed herein do not necessarily state or reflect those of the United States Government or any agency thereof.

This report has been reproduced directly from the best available copy.

Available for sale to the public, in paper, from: U.S. Department of Commerce, National Technical Information Service, 5285 Port Royal Road, Springfield, VA 22161, phone: (800) 553-6847, fax: (703) 605-6900

email: orders@ntis.fedworld.gov

online ordering: http://www.ntis.gov/help/index.asp

Available electronically at http://www.osti.gov/bridge

Available for a processing fee to U.S. Department of Energy and its contractors, in paper, from: U.S. Department of Energy, Office of Scientific and Technical Information, P.O. Box 62, Oak Ridge, TN 37831-0062,

phone: (865)576-8401,

fax: (865)576-5728

email: $\underline{\text { reports@ adonis.osti.gov }}$ 
This page intentionally left blank 


\section{TABLE OF CONTENTS}

\begin{tabular}{|c|c|}
\hline 1.0 & MMARY \\
\hline 2.0 & INTRODUCTION AND BACKGROUND . \\
\hline 3.0 & EXPERIMENTAL ......................................... \\
\hline 3.1 & Sludge Simulant and Slurry Preparation. \\
\hline 3.2 & Procedures and Equipment Used in Testing. \\
\hline 4.0 & ANALYTICAL \\
\hline 5.0 & SRAT/SME RUN RESULTS. \\
\hline 5.1 & Starting Sludge Composition... \\
\hline 5.2 & SRAT and SME Processing.... \\
\hline 5.3 & 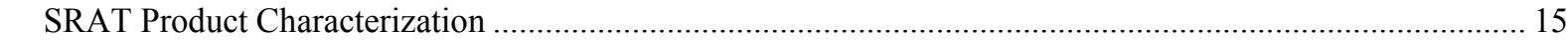 \\
\hline 5.4 & SME Product Characterization ............. \\
\hline 6.0 & CONCLUSIONS AND PATH FORWARD \\
\hline 7.0 & REFERENCES .. \\
\hline 0 & KNOWLEDGN \\
\hline
\end{tabular}

\section{LIST OF TABLES}

Table 1: Projected and Actual Levels of Noble Metals Used in Testing .................................................................. 5

Table 2: Pre-Run Measured Inputs and Assumptions for Acid Calculation .................................................................... 9

Table 3: In-Process Slurry Anion Concentrations Based on Weighted Dilutions (mg/Kg) ....................................... 12

Table 4: Peak Volume \% and Mass of Hydrogen, Carbon Dioxide, and Nitrous Oxide Gases Generated ..................... 15

Table 5: SRAT Product Anion Concentration $(\mathrm{mg} / \mathrm{kg})$...................................................................................... 15

Table 6: Destruction of Nitrate, Formate, and Oxalate - SRAT Receipt Relative to SRAT Product.............................. 16

Table 7: SRAT Product Results (Calcined Solids Wt\%) .......................................................................................... 17

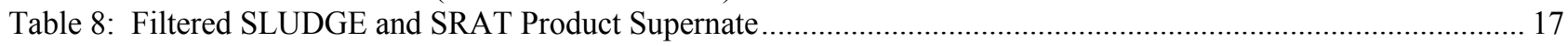

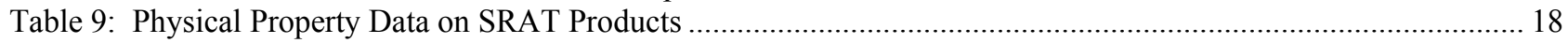

Table 10: SME Product Anion Concentration (mg/kg) ….................................................................................. 19

Table 11: Destruction of Nitrate, Formate, and Oxalate - SRAT Product Relative to SME Product and SRAT Receipt

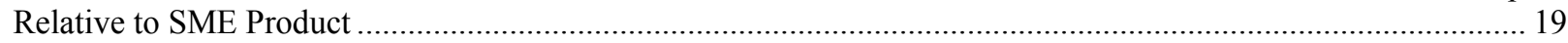

Table 12: Post-Run Measured Inputs and Assumptions for Acid Calculation ............................................................ 20

Table 13: SME Product Results (Calcined Solids Wt\%) .................................................................................... 21

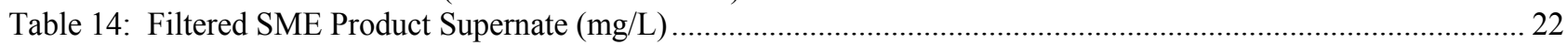

Table 15: Physical Property Data on SME Products ……............................................................................................. 22

Table A - 1: SB3 Simulant Sludge Composition and Chemicals Used to Adjust the Sludge to Match the Target

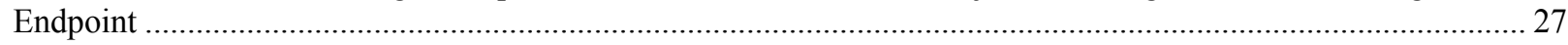

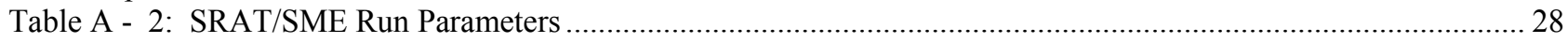

Table A - 3: Analyzed Composition of the Starting Sludges ................................................................................... 29

Table A - 4: Other Measured Properties for Starting Adjusted Sludges .................................................................... 29

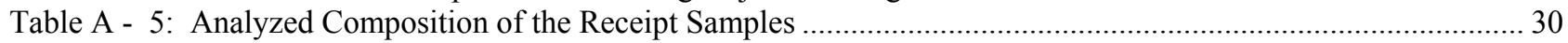

Table A - 6: SRAT/SME Operating Data and Mass Balance for Run SB3A-14 ....................................................... 31

Table A - 7: SRAT/SME Operating Data and Mass Balance for Run SB3A-15 ….................................................... 32

Table A - 8: SRAT/SME Operating Data and Mass Balance for Run SB3A-16 ........................................................ 33

Table A - 9: SRAT/SME Operating Data and Mass Balance for Run SB3A-17 ….................................................. 34

Table A - 10: SRAT/SME Operating Data and Mass Balance for Run SB3A-18 …................................................... 35

Table A - 11: SRAT/SME Operating Data and Mass Balance for Run SB3A-19 …................................................... 36

Table A - 12: SRAT/SME Operating Data and Mass Balance for Run SB3A-20 …................................................... 37 


\section{LIST OF FIGURES}

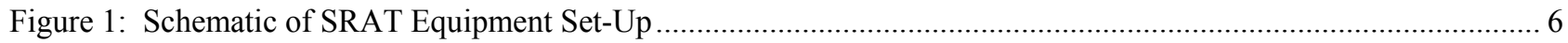

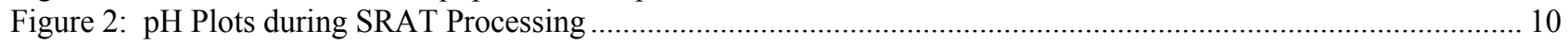

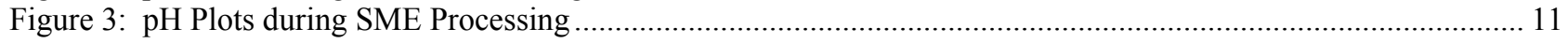

Figure 4: Hydrogen Generation on a DWPF Scale for SRAT …….................................................................... 13

Figure 5: Hydrogen Generation on a DWPF Scale for SME ............................................................................ 14

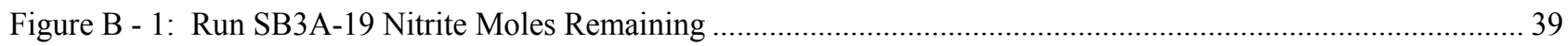

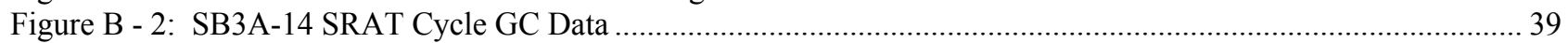

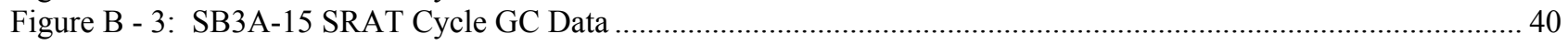

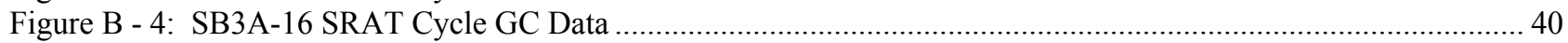

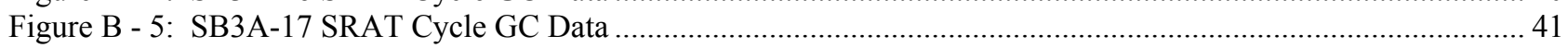

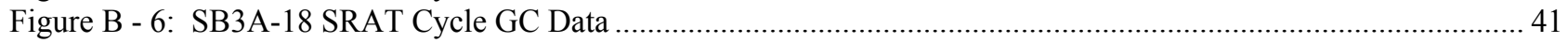

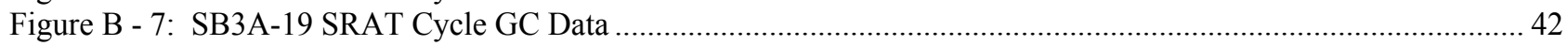

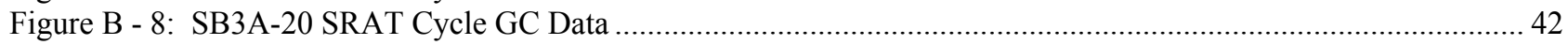

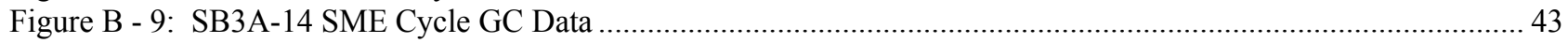

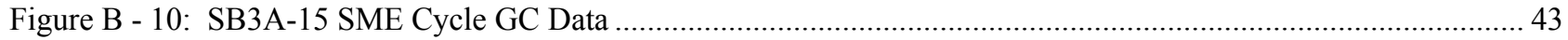

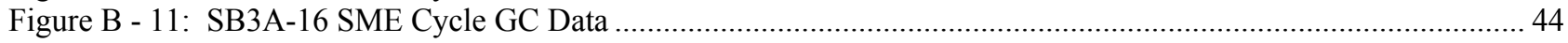

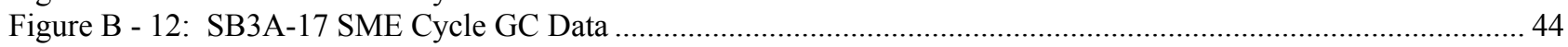

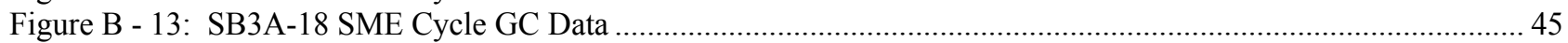

Figure B - 14: SB3A-19 SME Cycle GC Data ................................................................................................ 45

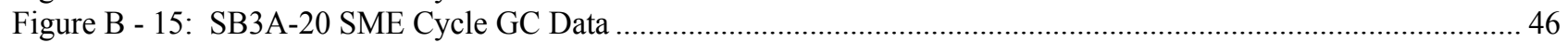




\subsection{EXECUTIVE SUMMARY}

Simulant flowsheet runs have been performed by the Savannah River Technology Center (SRTC) - Immobilization Technology Section (ITS) for every sludge batch that has been qualified for Defense Waste Processing Facility (DWPF) processing. The next sludge batch to be qualified is Sludge Batch 3 (SB3). The simulant Chemical Process Cell (CPC) runs for SB3 were designed to meet the requirements of Technical Task Request HLW/DWPF/TTR-02-0016 [1].

Due to the many non-traditional components (i.e., sand, coal, and sodium oxalate) believed to be in SB3, SRTC has focused significant effort on studies to understand the behavior of SB3 and to evaluate any necessary process changes. The simulant flowsheet runs for the chemical process cell were divided into phases. A phased approach was used to obtain a better understanding about the non-traditional components and to allow flexibility to respond to characterization results as they became available. The first two phases were based on the projected composition for SB3 and contained significant quantities of oxalate. These findings were previously documented in WSRC-TR-200300088 [2] and WSRC-TR-2003-00158 [3]. A third phase was initiated based on the Tank 7 results and preliminary blending and decanting scenarios. The results were also documented elsewhere.[4]

The final phase of the flowsheet studies was initiated after the characterization of the SB3 - Tank 51 qualification sample was completed. The Closure Business unit used the characterization information combined with the projected decant and $\mathrm{Pu}$ and $\mathrm{Np}$ transfer/blending information to project final SB3 in Tank 51 compositions with different decant/wash endpoints. All of the compositions in the most recent projections contained higher quantities of sodium salts than previous DWPF sludge batches due to the need to minimize washing and to accommodate miscellaneous waste streams to help with accelerated closure.

For the flowsheet runs, the ITS adjusted the existing SB3 simulant to match the projected decant compositions. Seven flowsheet runs were performed to meet the objective of determining an acceptable processing region. The primary intention of the final phase of runs was to assist in defining the acceptable decant/wash endpoint for SB3 - Tank 51. This information was needed by the Closure Division to define their decant/wash strategy and to support qualification of SB3 in the Shielded Cells.

Both Sludge Receipt and Adjustment Tank (SRAT) and Slurry Mix Evaporator (SME) cycles were performed. The composition endpoints tested included:

Case $6 \mathrm{~b}$ SB3A-14 Nominally $26,000 \mathrm{mg} / \mathrm{kg}$ nitrite, highest acid, Tank 7 noble metals

SB3A-15 Nominally $26,000 \mathrm{mg} / \mathrm{kg}$ nitrite, low acid, Tank 7 noble metals

SB3A-16 Nominally $26,000 \mathrm{mg} / \mathrm{kg}$ nitrite, higher acid, Tank 7 noble metals

20K Case SB3A-17 SB3 at decant scenario with $20,000 \mathrm{mg} / \mathrm{kg}$ nitrite, low acid, $110 \%$ of SB3 noble metals

SB3A-18 SB3 at decant scenario with $20,000 \mathrm{mg} / \mathrm{kg}$ nitrite, high acid, $110 \%$ of SB3 noble metals

24K Case SB3A-19 SB3 at decant scenario with $24,000 \mathrm{mg} / \mathrm{kg}$ nitrite, low acid, $110 \%$ of SB3 noble metals

SB3A-20 SB3 at decant scenario with $24,000 \mathrm{mg} / \mathrm{kg}$ nitrite, high acid, $110 \%$ of SB3 noble metals

For the three cases, each run represented a different acid addition amount. Different levels of acid were used to try to determine processing windows where nitrite was destroyed and excessive hydrogen was not generated. For the SME cycles, Frit 202 was used since it was readily available, and the target waste loading was $38 \mathrm{wt} \%$ on an oxide basis. The waste loading selected was the midpoint of the waste loading operating window.

For the target endpoints tested at the projected SB3 - Tank 51 noble metal levels, ITS recommended the 24K nitrite case for the target Closure Division decant/blend scenario for SB3 and for qualification of SB3. This scenario provided an acceptable window to destroy nitrite and mitigate excessive hydrogen generation for qualification of SB3. Although the exact upper and lower bounds of the window were not defined, the testing at this endpoint indicated that acceptable processing should be possible.

The following insights into SRAT/SME processing for sludges at the proposed endpoints were gained:

- At the tested levels of noble metals and for each decant endpoint, the testing showed that excessive acid can result in excessive hydrogen generation. In all of the decant scenarios, hydrogen was more problematic in the SME than the SRAT. Unlike previous SB3 flowsheet runs where peak hydrogen was seen in the SRAT $[3,4,5]$, the levels of hydrogen generated in the SME were more problematic. In fact, only the highest acid addition amount in the Case $6 \mathrm{~b}$ runs resulted in a significant peak being seen in the SRAT. The other runs had some hydrogen generation in the 
SRAT that started to increase near the end of the SRAT cycle and continued into the SME cycle. The explanation for this behavior is not known; however, it could possibly be due to the large amount of formic acid used in the runs or the distribution/concentration of the noble metals. For the $24 \mathrm{~K}$ nitrite case, the acid addition amount, 2.154 moles $\mathrm{H}^{+} /$liter of slurry with 2.064 moles/liter as formic acid, did not create unacceptable hydrogen levels in either the SRAT or the SME. A general conclusion for this series of testing was that excess formic acid less than $\sim 0.29$ moles/liter of slurry resulted in acceptable levels of hydrogen generation. The excess amount was considered relative to the amount necessary for nitrite destruction. The data indicates that if DWPF were to process SB3 without combining with sludge batch 2, then additional studies may have to define an upper limit on the acid addition amount if the noble metal behavior is the same in the actual sludge. This limit would best be placed on the amount of formic acid since its addition primarily drives the hydrogen generation. This information may also be necessary for the combination of sludge batch 3 with sludge batch 2 .

- As expected, the minimum SRAT pH was obtained at the end of acid addition, and was below 4.9 for all runs. During SRAT processing, the $\mathrm{pH}$ gradually increased and was highly dependent on the amount of acid added. The lower acid run for each case had a SRAT product $\mathrm{pH}$ in the range of 6 to 7 , while the higher acid runs had a $\mathrm{pH}<6$. The slurry $\mathrm{pH}$ oscillated during the frit addition/concentration part of the SME cycle, but by the end of the SME cycle, only a small increase in $\mathrm{pH}$ was evident. All SME products were $<7$. These $\mathrm{pH}$ values are those measured at boiling versus in the analyzed products, which tend to be generally higher than those measured at boiling.

- $\quad$ SRAT formate destruction was lowest for the $20 \mathrm{~K}$ nitrite case and was similar for the other cases. The $24 \mathrm{~K}$ nitrate case had formate destruction of $\sim 21$ to $23 \%$. SME formate destruction was small in general and ranged from $\sim 2$ to $6 \%$ for the $24 \mathrm{~K}$ nitrite case. Formate destruction was comparable to that seen during qualification of sludge batch 2.[6] Significant nitrate was created in the SRAT, while very small amounts were destroyed during the SME. For the $24 \mathrm{~K}$ case, nitrite to nitrate conversion was $\sim 31$ to $41 \%$ in the SRAT. Nitrite to nitrate conversion was higher in this set of runs than for qualification of sludge batch $2[6]$ and than what has been seen in other simulant runs, which may have been due to the high levels of nitrite present in the starting sludge. Oxalate destruction varied greatly during the testing ranging from very little destroyed to $\sim 60 \%$ destroyed in the SRAT. Similar behavior was seen in the SME. This wide range of oxalate destruction may be attributed to the small quantities present and the difficulty with analyzing this small amount.

- The peak $\mathrm{CO}_{2}$ concentration was seen during the SRAT in the $24 \mathrm{~K}$ nitrite case - low acid run (SB3A-19) and was $\sim 37$ volume percent. Generally speaking, three peaks of $\mathrm{CO}_{2}$ generation were seen in each SRAT run, with the magnitude ranging from $\sim 12$ to $\sim 37$ volume percent. The two most significant peaks usually occurred two hours before the end of acid addition or at the end of acid addition, with the third peak usually occurring as the vessel went to boiling. Peaks of $\mathrm{CO}_{2}$ continued to be generated through the SME cycles but were of much lower magnitude. They also usually corresponded to the time of hydrogen peaks and when dewatering was occurring.

- The $24 \mathrm{~K}$ nitrite case - high acid run (SB3A-20) had the greatest peak nitrous oxide concentration of $\sim 2.4$ volume percent during the SRAT and $\sim 0.1$ volume percent during the SME. Typically two major peaks of nitrous oxide were seen during the SRAT, which occurred near the end of acid addition and near the end of dewatering/ concentration. Near the end of formic acid addition in the SRAT cycles, the timing of one of the nitrous oxide and $\mathrm{CO}_{2}$ peaks corresponded with a complete depletion of oxygen. Oxygen returned to normal levels after the completion of acid addition and upon going to boiling. Other than the peaks of nitrous oxide generated with the $\mathrm{H}_{2}$ and $\mathrm{CO}_{2}$ during the SME concentrations, relatively small amounts of nitrous oxide were generated throughout the SME cycles.

- For the 24K nitrite case, the SRAT and SME product supernates were analyzed to determine the relative percent of soluble species. Of note was the increased solubility of $\mathrm{Mn}, \mathrm{Cu}, \mathrm{Ni}$, and $\mathrm{Zn}$ in the SRAT products with increased acid levels. However, the higher acid run showed a slight decrease in these elements' solubility in the SME products. Mn solubility was nearly $100 \%$ in the higher acid run for the SRAT product, indicating total reduction of $\mathrm{Mn}^{+4}$ to $\mathrm{Mn}^{+2}$ compared to a target of $60 \%$. Significant quantities of the $\mathrm{Ca}$ and $\mathrm{Mg}$ were also soluble, which is expected based on the anticipated SRAT reactions with formate.

- Based on the simulants used, no foaming or processing issues such as air entrainment were identified. A small amount of foaming was seen in the high acid $20 \mathrm{~K}$ case run during formic acid addition. The foam was quickly mitigated with the addition of $100 \mathrm{ppm}$ of antifoam. The antifoam had not been added between nitric and formic acid addition, so the amount of antifoam would be no more than the current DWPF antifoam strategy. Visually, the sludge slurry appeared to be very thin, and no problems with mixing or heating were encountered. 
A separate recommendation memo will be written for the Shielded Cells qualification of SB3. This memo will recommend the acid stoichiometry based on the operating region defined here and the sensitivity analysis being performed by T.B. Edwards and J.R. Harbour.

\subsection{INTRODUCTION AND BACKGROUND}

SRTC was requested by DWPF via Technical Task Request (TTR) HLW/DWPF/TTR-02-0016 to perform flowsheet studies to qualify SB3.[1] The flowsheet runs are required for each sludge batch that is processed in DWPF so an evaluation of potential chemical processing issues, quantification of the potential hydrogen generation rates, and estimation of the required acid stoichiometry for that sludge batch can be made. SB3 will consist of the heel in Tank 51 (Sludge Batch 1B), and material from Tanks 7, 18, and 19. Disposition material from an H-Canyon slurry containing precipitated $\mathrm{Pu}$ with $\mathrm{Gd}$, an $\mathrm{H}$-canyon $\mathrm{Np}$ stream, and an $\mathrm{Am} / \mathrm{Cm}$ stream have or will also be added. SB3 may also be processed with a monosodium titanate stream from the Actinide Removal Process (ARP) depending on when the process comes on line. The ARP stream will be addressed in a separate study.

In response to the SB3 flowsheet TTR [1], a Task Technical \& Quality Assurance Plan [7] was written outlining the activities and controls necessary to meet the objectives and requirements of the TTR. The task plan outlined a twophased approach to meet the objectives. The first phase, Phase I, performed tests to assist in the determination of a SB3 acid addition equation and bounded the possible processing scenarios for sodium oxalate in SB3 processing. The results of the Phase I testing were documented in WSRC-TR-2003-00088.[2] The second phase, Phase II, was performed to test the acid addition and redox equations developed for SB3 [8,9] and to bound the SB3 processing window for acid addition. The results of the Phase II testing were documented in WSRC-TR-2003-00158.[3] After the completion of the Phase I and Phase II testing, analytical characterization of the Tank 7 samples was completed. This data revealed that oxalate, coal, and the noble metals were at levels much lower than anticipated.[ 10,11,12] In addition, the washing and decanting strategy for SB3 was changed significantly due to the lack of oxalate in Tank 7 and increase in sodium compounds (e.g., nitrite, nitrate, and hydroxide) to be added to accommodate SB3 processing of the $\mathrm{Pu}$ and $\mathrm{Np}$ disposition streams. Therefore, additional runs had to be performed to define the processing strategy for the Shielded Cells run with the qualification sample (Shielded Cells run will be performed as a separate TTR).

SRTC used composition predictions by the Closure Business Unit to bound the sodium and anion concentrations that might be expected for processing of SB3 only. ${ }^{1}$ The original baseline and alternate decant/washing strategies were defined in CBU-PED-2003-00117.[13] The data from chemical process cell studies with the baseline scenario (Case 6) and alternate (Case 7) washing/decant scenarios were documented in WSRC-TR-2003-00283.[4] These scenarios were further revised after receiving the qualification characterization data from the SB3 - Tank 51 sample. The latest transfer and flushing scenarios for the H-Canyon streams were also included in the revised SB3 composition estimates. Three different nitrite endpoints were considered in the studies to help define the target sludge anion concentration endpoint for the qualification of the SB3 - Tank 51. All of the tested scenarios in this phase did not consider an additional wash and instead represented different methods for decanting and blending the potential SB3 streams. For each nitrite endpoint, a lower and upper acid addition amount was tested to try to find an operating window for the endpoint. The lower acid amount was intended to find the minimum acid required to meet nitrite destruction, while the upper acid amount attempted to bound the amount of acid that could be added without exceeding the hydrogen generation limit. For one of the nitrite endpoints, two different upper acid addition levels were tested since the first test exceeded the hydrogen generation limit. This final phase of the testing used the levels of noble metals determined from the Tank 7 sample characterization and the SB3 - Tank 51 characterization since their concentration directly impacts the amount of hydrogen generated.

The non-traditional components in SB3 (i.e., sand, coal and oxalate) were also added at their anticipated levels based on the Tank 7 and SB3 characterization. Only the anions and sodium associated with the H-Canyon slurry streams containing the $\mathrm{Pu}$ and $\mathrm{Np}$ were addressed since only simulant testing was performed. The qualification runs in the Shielded Cells will help ascertain impacts of radioactive components of these streams; however, due to small concentration relative to the other components, they are not expected to have a major effect. Limited testing with the $\mathrm{Am} / \mathrm{Cm}$ feed has already been performed by the Waste Processing Technology Section, along with a literature review

\footnotetext{
${ }^{1}$ J.M. Gillam used his decanting/washing spreadsheets to calculate the projected Tank 51 composition after blending with $\mathrm{Pu}$ and $\mathrm{Np}$. This was based on the existing tank nitrite inhibitor strategy (molar ratio of 1.67 nitrite to nitrate).
} 
and paper study.[14] The stream of MST from the ARP was also not addressed, but separate flowsheet studies examining the impact of the ARP stream have been performed and documented.[15]

As stated above, the primary objective of the final phase of testing was to determine the decant/wash endpoint for SB3, so qualification of the sludge could be performed in the Shielded Cells. This information will also be used by the Closure Division to determine their decant washing plan for SB3. To fulfill the TTR requirements, the final phase of testing also had to provide the following information for the different endpoints:

- Hydrogen, carbon dioxide, and nitrous oxide generation rates;

- The amount of formate and nitrate remaining after the SRAT cycle; and

- Any unusual observations during processing.

Slurry Mix Evaporator (SME) cycles were performed for all of the runs in this phase using Frit 202 at a 38 wt $\%$ waste oxide loading. Frit 202 does not necessarily represent the optimum frit for the projected SB3 composition, but was readily available and did have a processing window.

Seven runs were performed as part of the final phase of the SB3 simulant flowsheet testing, and they were identified as follows:

Case $6 \mathrm{~b}$ SB3A-14 Nominally $26,000 \mathrm{mg} / \mathrm{kg}$ nitrite, highest acid, Tank 7 noble metals

SB3A-15 Nominally $26,000 \mathrm{mg} / \mathrm{kg}$ nitrite, low acid, Tank 7 noble metals

SB3A-16 Nominally $26,000 \mathrm{mg} / \mathrm{kg}$ nitrite, higher acid, Tank 7 noble metals

20K Case SB3A-17 SB3 at decant scenario with 20,000 $\mathrm{mg} / \mathrm{kg}$ nitrite, low acid, $110 \%$ of SB3 noble metals

SB3A-18 SB3 at decant scenario with $20,000 \mathrm{mg} / \mathrm{kg}$ nitrite, high acid, $110 \%$ of SB3 noble metals

24K Case SB3A-19 SB3 at decant scenario with $24,000 \mathrm{mg} / \mathrm{kg}$ nitrite, low acid, $110 \%$ of SB3 noble metals

SB3A-20 SB3 at decant scenario with $24,000 \mathrm{mg} / \mathrm{kg}$ nitrite, high acid, $110 \%$ of SB3 noble metals

\subsection{EXPERIMENTAL}

The experimental section is divided into two subsections. The first, Section 3.1, describes the sludge simulant used in the final phase of testing. Section 3.2 describes the procedures and equipment utilized in the testing.

\subsection{Sludge Simulant and Slurry Preparation}

The runs were performed using the same SB3 simulant used in the earlier phases of flowsheet testing. The sludge was prepared at the Clemson Environmental Technologies Laboratory (CETL) and is representative of the primary sludge components. The composition of the as-fabricated SB3 surrogate is given in Table A - 1 of Appendix A. The SB3 surrogate as fabricated is low in sodium, which was done intentionally to allow for adjustment to the anion concentrations with sodium compounds. Since three different endpoints were tested during this phase of testing, three different adjustments to the SB3 simulant had to be performed. Table A - 1 also shows the chemicals added to obtain the desired decant endpoints. The Case $6 \mathrm{~b}$ endpoint was fabricated on two occasions since testing was performed at two different times.

The sludges, however, did not contain the non-typical or minor sludge components. Therefore, trim chemicals were added to the simulants to represent the sand, coal, mercury, and noble metals present in SB3. As with earlier testing, the sand and coal are from the vendor of the sand filter material that was believed to have been transferred to Tank 7 . For the Case $6 \mathrm{~b}$ runs, the Tank 7 results were used to define the addition levels, and the addition was added based on the ratio of that component to $\mathrm{Fe}$ in the actual sludge. Mercury was detected at $0.167 \mathrm{wt} \%$ of the total solids in the second Tank 7 sample, and was added at $0.351 \mathrm{wt} \%$ of the total solids in the Case $6 \mathrm{~b}$ run.[16] Coal was conservatively estimated to be $0.07 \mathrm{wt} \%$ in the total solids for the Tank 7 samples, but one of the analytical methods indicated that it could be as high as $0.20 \mathrm{wt} \%$ in the total solids.[11] For conservatism and to maintain the ratio to Fe, a target of 0.25 $\mathrm{wt} \%$ coal in the total solids was used for the Case $6 \mathrm{~b}$ runs. An accurate sand analysis could not be performed since small amounts of silicon are also present in the sludge; therefore, a target sand concentration of $0.74 \mathrm{wt} \%$ in the total solids was used and was scaled to the amount of $\mathrm{Fe}$ and the amount of coal present. For the $20 \mathrm{~K}$ and $24 \mathrm{~K}$ case runs, measurements from the SB3 - Tank 51 qualification sample initial characterization were used with the exception of mercury. Only very small amounts of mercury were detected in the SB3 - Tank 51 sample, i.e., $0.024 \mathrm{wt} \%$ of the total 
solids.[17] Therefore, an addition level similar to that used in the Case $6 \mathrm{~b}$ runs was used (with proper adjustment to the Fe content) for conservatism since mercury concentration is an acid addition equation input parameter. Mercury addition was targeted to give $0.30 \mathrm{wt} \%$ mercury in the total solids. Coal analyses of the SB3 - Tank 51 sample indicated a possible concentration of $\geq 0.004 \mathrm{wt} \%$ coal and $\leq 0.07 \mathrm{wt} \%$ in the total solids.[18] A target of $0.05 \mathrm{wt} \%$ coal in the total solids was used for the $20 \mathrm{~K}$ and $24 \mathrm{~K}$ cases to bracket the upper coal limit with scaling to the Fe content.

The two different levels of noble metals used in the final phase of testing are shown in Table 1. The noble metals for Case $6 \mathrm{~b}$ were added based on the measured noble metals in the second Tank 7 sample, while the $20 \mathrm{~K}$ and $24 \mathrm{~K}$ case were added based on the measured noble metals in the SB3 - Tank 51 sample. To better approximate the actual mass of noble metals present in the SRAT vessel for the $20 \mathrm{~K}$ and $24 \mathrm{~K}$ case, the proportion of the simulant insoluble solids and total solids were scaled to the actual sludge insoluble solids to determine the level of noble metals in the simulant total solids. The intent was to give approximately the same mass of noble metals in the simulant versus the actual waste since the noble metals play the primary role in hydrogen generation. For added conservatism and to cover the analytical uncertainty, the added amount was increased by $110 \%$. The actual amounts of the added trim chemicals are noted in Table A - 2 of Appendix A.

Table 1: Projected and Actual Levels of Noble Metals Used in Testing

\begin{tabular}{|c|c|c|c|c|c|c|}
\hline \multirow[b]{2}{*}{$\begin{array}{l}\text { Noble } \\
\text { Metal }\end{array}$} & \multicolumn{2}{|c|}{ Tank $7-2^{\text {nd }}$ Sample* } & \multirow{2}{*}{$\begin{array}{c}\begin{array}{c}\text { Case 6b } \\
\text { Target }\end{array} \\
\begin{array}{c}\text { Wt\% in } \\
\text { Total Solids }\end{array}\end{array}$} & \multicolumn{2}{|c|}{ SB3 - Tank 51* } & \multirow{2}{*}{$\begin{array}{c}\text { 20K and 24K } \\
\text { Cases Target } \\
\begin{array}{c}\text { Wt\% in Total } \\
\text { Solids }\end{array}\end{array}$} \\
\hline & $\begin{array}{c}\text { Wt\% in } \\
\text { Insoluble } \\
\text { Solids }\end{array}$ & $\begin{array}{l}\text { Wt } \% \text { in Total } \\
\text { Solids }\end{array}$ & & $\begin{array}{c}\text { Wt } \% \text { in } \\
\text { Insoluble Solids }\end{array}$ & $\begin{array}{c}\text { Wt\% in } \\
\text { Total } \\
\text { Solids } \\
\end{array}$ & \\
\hline $\mathrm{Ag}$ & $2.1 \mathrm{E}-02$ & $6.4 \mathrm{E}-03$ & $1.7 \mathrm{E}-02$ & $1.7 \mathrm{E}-02$ & $9.1 \mathrm{E}-03$ & 1.2 E-02 \\
\hline $\mathrm{Pd}$ & $7.0 \mathrm{E}-03$ & $2.1 \mathrm{E}-03$ & 3.8 E-03 & 2.8 E- 03 & $1.5 \mathrm{E}-03$ & 2.0 E-03 \\
\hline $\mathrm{Rh}$ & $2.4 \mathrm{E}-02$ & 7.1E-03 & $1.2 \mathrm{E}-02$ & $1.0 \mathrm{E}-02$ & $5.5 \mathrm{E}-03$ & 7.1 E-03 \\
\hline $\mathrm{Ru}$ & $1.1 \mathrm{E}-01$ & $3.2 \mathrm{E}-02$ & $5.4 \mathrm{E}-02$ & $5.1 \mathrm{E}-02$ & $2.8 \mathrm{E}-03$ & $3.6 \mathrm{E}-02$ \\
\hline
\end{tabular}

*Per References [12] for Tank 7 and [17] for SB3

\subsection{Procedures and Equipment Used in Testing}

The testing was once again performed at the Aiken County Technology Laboratory (ACTL) using four-liter kettles with various glassware fabricated to functionally replicate the DWPF processing vessels. The 4-liter glass kettle is used to replicate both the SRAT and the SME, and it is connected to the SRAT Condenser, the Mercury Water Wash Tank (MWWT), the Slurry Mix Evaporator Condensate Tank (SMECT), and the Formic Acid Vent Condenser (FAVC). For the purposes of this paper, the condensers and wash tank are referred to as the offgas components. A sketch of the experimental setup is given as Figure 1. 
Figure 1: Schematic of SRAT Equipment Set-Up

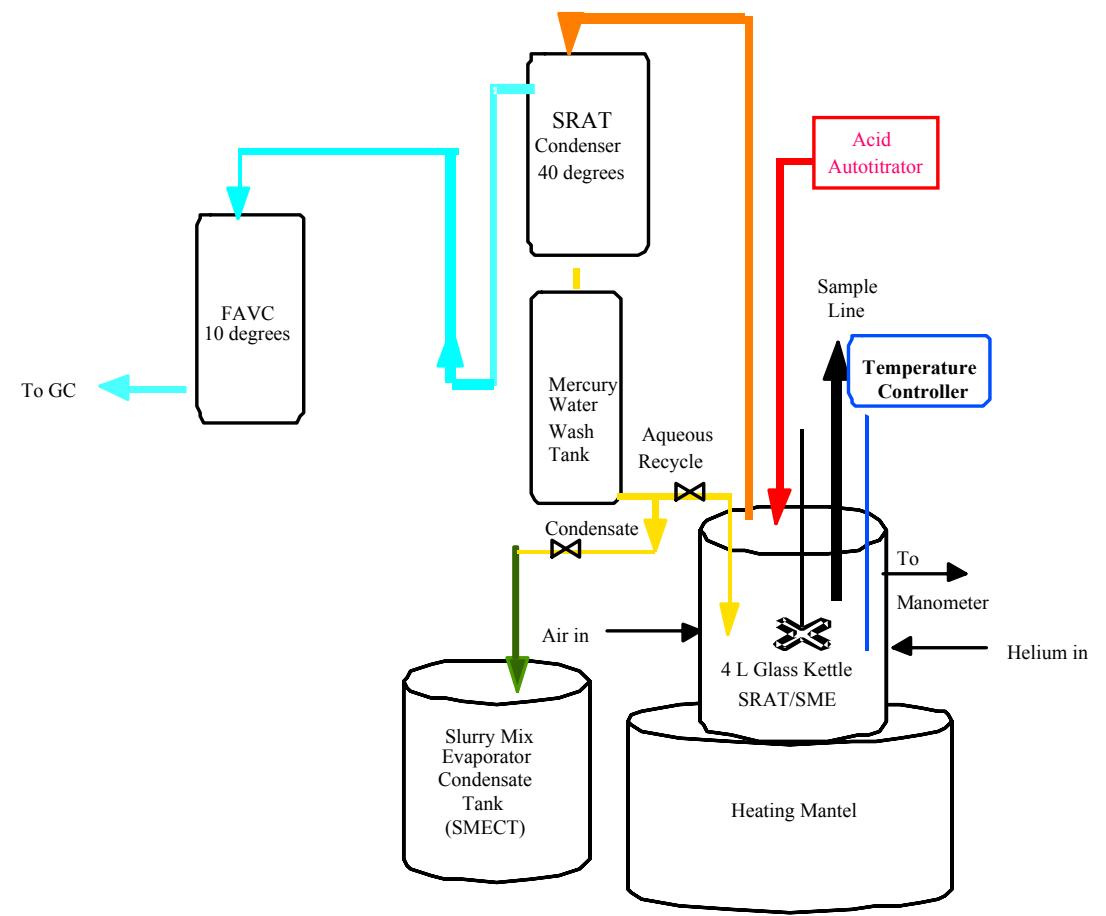

SRAT/SME processing followed the run plans written for each run, and the memo numbers are given in Table A-2 of Appendix A. The runs were performed in accordance with Procedure 2.02 ("Laboratory Scale Chemical Process Cell Simulations") of Manual L27 [19]. Slurry pH and offgas hydrogen, nitrous oxides, and carbon dioxide concentrations were measured during the experiments using in-line instrumentation, so that total amounts generated and peak generation rates could be calculated. During the runs, the kettle was monitored to observe reactions that were occurring during each run to include foaming, air entrainment, rheology changes, loss of heat transfer capabilities, and offgas carryover. Observations were recorded in laboratory notebooks WSRC-NB-2003-00117 and WSRC-NB-2003-00118 and are discussed in Section 5.

Concentrated nitric acid (50-wt\%), where necessary, and formic acid (90-wt $\%)$ were used to acidify the sludge and perform neutralization and reduction reactions during processing. The amounts of acid to add for each run were determined using the existing DWPF acid addition equation. As mentioned earlier, different levels of acid were used in each of the runs with the original targets shown in Table A - 2 and the calculated values based on the runs given in Section 5. The split of the acid was determined using the redox equation proposed for SB3 processing.[9] The redox target of $\mathrm{Fe}^{2+} / \Sigma \mathrm{Fe}$ of 0.2 was used for runs SB3A-14 through 18 and a ratio of $0.1 \mathrm{Fe}^{2+} / \Sigma \mathrm{Fe}$ was used for SB3A-19 and SB3A-20. The lower redox target was used for runs SB3A-19 and SB3A-20 to allow for the addition of nitric acid in the flowsheet. To account for the reactions and anion destructions that occur during processing, assumptions about nitrite destruction, nitrite to nitrate conversion, formate destruction, and oxalate destruction were made for each run. The values used for each run are provided in Section 5.

To prevent foaming during processing, $200 \mathrm{ppm}$ IIT 747 antifoam was added during heat-up at $40^{\circ} \mathrm{C}$ and $400 \mathrm{ppm}$ was added at the completion of acid addition. The addition strategy was conservative relative to the current DWPF addition strategy to increase sensitivity to foaming issues, and no recommendations on changes to the antifoam addition strategy will be made based on this testing. SRAT processing included the dewater time in boiling plus an additional 12 hours of reflux to simulate DWPF processing conditions. Run SB3A-19 was refluxed a total of 39 hours to try to destroy nitrite to $<1000 \mathrm{mg} / \mathrm{kg}$ without adding significantly more acid. This was done to try to find the minimum acid level without over-adding acid and to help understand if additional boiling would help destroy the nitrite. The dewater and reflux time for all of the runs is given in Table A - 2 of Appendix A. The SME cycle included three frit additions and concentrations. The SME cycle for the Case $6 \mathrm{~b}$ runs (SB3A-14 through SB3A-16) were performed at the scaled DWPF 
target boil-up rate and were approximately 8 hours in duration. For runs SB3A-17 through SB3A-20, however, a boilup rate that more closely matched the obtainable DWPF boil-up rate was used and additional reflux was performed to more closely match the DWPF processing time and to help ascertain the peak hydrogen generation. Once again, boil-up rates and times are given in Table A - 2 .

\subsection{ANALYTICAL}

Analyses for this task and all other phases of the flowsheet testing used guidance of Analytical Study Plan (ASP) WSRC-RP-2002-00577.[20] Sample request forms were used for samples to be analyzed, and analyses followed the guidelines and means of sample control stated in the ASP for the task. A unique lab identification number was assigned to each sample for tracking purposes. Analyses were performed using approved analytical and QA procedures.

Samples were taken before the runs were initiated ("Sludge" and "Receipt" samples), throughout the runs ("IC" samples), and at the end ("Product" samples) of the SRAT/SME cycles for analyses to quantify the processing behavior. The samples were analyzed by the Immobilization Technology Section - Mobile Lab (Mobile Lab), the Immobilization Technology Section (ITS), and the Analytical Development Section (ADS). The Mobile Lab performed analyses on the sludge slurries to determine the chemical composition, total and dissolved solids, density, and $\mathrm{pH}$. The chemical composition was determined in duplicate by calcining the samples at $1100^{\circ} \mathrm{C}$ and then dissolving the product using $\mathrm{Na}_{2} \mathrm{O}_{2} / \mathrm{NaOH}$ fusion, lithium metaborate fusion, and aqua regia dissolution. The preparations were then analyzed using Inductively Coupled Plasma - Atomic Emission Spectroscopy (ICP-AES) to measure the cations present. The filtered supernate was also measured using ICP-AES to determine the soluble cations present in select samples. Samples for anion analyses were prepped using weighted dilutions and were analyzed using Ion Chromatography (IC). For oxalate determinations, an additional preparation step involving a $\mathrm{HCl} / \mathrm{HNO}_{3}$ strike had to be performed before analyses. The samples taken throughout the runs for anion analyses were diluted with a $1 \mathrm{~N} \mathrm{NaOH}$ solution immediately after the sample was removed from the vessel to quench the reactions. Other than this different preparation method, they were analyzed using the same techniques. The total and dissolved solids were measured on two aliquots and the insoluble and soluble solids fractions were calculated from the results. Density and $\mathrm{pH}$ measurements of the samples were also performed on the initial and product samples. ITS performed the titration on the starting sludge and receipt samples to provide the necessary input for the acid calculation. The titration is performed using an autotitrator and a 30:1 dilution of the sample. This is similar to the method used by the DWPF. The titration was performed to both a $\mathrm{pH} 5.5$ and 7 endpoint and was performed in duplicate at a minimum. Finally, the ADS measured the total inorganic carbon/total carbon of the starting "Sludge" and/or the "Receipt" samples for the runs. Due to the presence of coal in some of the samples, the slurry samples were ground to try to ensure homogenization of the sample before introduction into the analyzer. The total inorganic carbon information was needed as an input in the acid calculation.

Hydrogen, oxygen, nitrogen, carbon dioxide, and nitrous oxide were monitored during the runs using a high-speed micro Gas Chromatograph (GC). Monitoring these species provides insight into the reactions occurring during processing and demonstrates whether a flammable mixture is formed. Helium was used as a GC internal standard and was also monitored during the runs. The GC is self-contained and is designed specifically for fast and accurate analysis. The GCs had five main components. The first is the carrier gas (argon for this testing) to transport the sample through the molecular sieve and poraplot Q columns. The second is the injector, which introduces a measured amount of sample into the inlet of the analytical columns where it is separated. The third component is the column, which is capillary tubing coated or packed with a chemical substance known as the stationary phase that preferentially attracts the sample components. As a result, components separate as they pass through the column based on their solubility. Since solubility is affected by temperature, column temperature is controlled during the run. The fourth component is a micro-machine thermoconductivity detector. The solid state detector monitors the carrier and senses a change in its composition when a component in the sample elutes from the column. The fifth component is the data system, EZChrom. Its main purpose is to generate both qualitative and quantitative data. It provides a visual recording of the detector output and an area count of the detector response. The detector response is used to identify the sample composition and measure the amount of each component by comparing the area counts of the sample to the analysis of known calibration standards. Two calibration standards were used in each run to bound upper and lower quantities of the expected gases. Calibration checks are performed before and after each run. The calibration standards are balanced in argon because helium is used as an internal standard and is also used to detect leakage during the actual runs. 


\subsection{SRAT/SME RUN RESULTS}

The data from the testing and any observations will be discussed in this section. This section has been divided into four subsections. Section 5.1 will discuss the analyses of the starting sludges and the necessary inputs for the acid calculation. Section 5.2 will discuss the results of the in-process samples, generated gas data, and general observations about processing. Finally, section 5.3 will discuss the SRAT product analyses, while section 5.4 will discuss the SME product analyses.

\subsection{Starting Sludge Composition}

As mentioned above, the SB3 simulant was the same as that used in the earlier phases of the flowsheet testing. However, as also mentioned above, it had to be adjusted to match the latest projections for the different decant endpoints. Each time the simulant was adjusted to a new endpoint, analyses of the resulting adjusted sludge was performed. Chemical analysis methods were described in Section 4.0. Table A - 3 of Appendix A provides the measured sludge compositions for each endpoint (with two analyzed compositions for the Case $6 \mathrm{~b}$ endpoint). This table also provides the targeted compositions for comparison. The analyses of the cations in the initial sludges indicate that most of the cations were within $10 \%$ of the target compositions. Some of the sludge components, $\mathrm{Cr}$, $\mathrm{Si}$, and $\mathrm{Zr}$, were consistently high, while $\mathrm{K}$ was consistently low. $\mathrm{Pb}$ was low for the Case $6 \mathrm{~b}$ and $20 \mathrm{~K}$ case sludges but high for the $24 \mathrm{~K}$ case sludge. Since these are minor components, it was felt that the differences did not present a problem for processing. Measured nitrite and nitrate are also given in Table A - 3 for comparison since they were a crucial parameter for testing the endpoints. All measured anions were within $\underline{ \pm} 8 \%$ of the target.

Other properties of the starting sludges were also measured and are reported in Table A - 4 of Appendix A. The results include IC data for oxalate and sulfate, solids information, carbon analyses, and titration results. Some variation in oxalate and sulfate concentration was seen between the cases and within the cases. Both values are once again fairly small and some problems with oxalate analyses were noted. Oxalate was believed to be present mostly in the solids requiring the acid preparation described in Section 4. Thus, with all of the dilutions, the amount present was small and more difficult to analyze accurately. The target total solids was $\sim 22 \%$ for all of the cases, so the adjusted sludges were fairly close to the target. The insoluble solids varied with each case with the highest level for the lowest anion case, as expected. The opposite behavior was seen for the soluble solids, also as expected. The calcined solids were all approximately the same. The slurry densities were also fairly similar and close to the anticipated density for the solids loading. The inorganic carbon measured values were close to target for Case $6 \mathrm{~b}$ and the $24 \mathrm{~K}$ case. The measured value for the $20 \mathrm{~K}$ case was almost twice the anticipated value as was the total carbon. Therefore, this value was not used, and the calculated value for the sludge was used based on the SB3 analyzed sludge and the amount added. Total inorganic carbon analysis consistently has been problematic in the SB3 simulant studies. $[2,3,4,5]$ The reason for the differences will continue to be pursued in future sludge studies.

In addition to the adjustment to the SB3 simulant to match the target endpoints, noble metals, $\mathrm{Hg}$, sand, and coal had to be trimmed into the sludge to match the projected compositions. The relative amounts of these components on either a total solids or insoluble solids basis were provided in Section 3.1. These additions have routinely been added to the SRAT kettle because they are present in small quantities. When they are added with the sludge, rinse water is also used to ensure that all chemicals and the sludge have been transferred and the amount used helps adjust the target total solids for the run. After the trim chemicals and sludge are thoroughly mixed in the kettle, a "Receipt" sample was taken to provide data on the material actually being processed in the SRAT. The analytical methods used were described in Section 4.0. Table A - 5 of Appendix A provides the results of the analyses of the "Receipt" samples. Only select analyses were performed on the SB3A-14 receipt sample due to the smaller batch size used for this run. Since the only difference between the "sludge" and "receipt" sample is the addition of noble metals, coal, sand, and water, very little difference was expected in the analytical results and the changes could be calculated based on the known addition amounts. Also, carbon analyses were performed on the $24 \mathrm{~K}$ case to provide a secondary verification of the data given the problems with carbon analyses on simulants. Little variation was seen for the receipt samples within a particular case. For Case 6b, the SB3A-14 sludge was appreciably lower in oxalate but was closer to the result in Table A -4 than the values reported for the SB3A-15 and SB3A-16 receipt samples. The data was assumed to be accurate and differences were attributed to possible mixing or batching errors or analytical error with the small quantity of oxalate. All of these problems are likely due to the analytical problems discussed earlier. Compared to the measured sludge compositions in Table A -3 , the receipt compositions were fairly consistent with a few exceptions. K was still low for the Case $6 \mathrm{~b}$ receipt and almost no $\mathrm{Si}$ was detected in Case $6 \mathrm{~b}$ even though it should have been higher due to the addition 
of sand. $\mathrm{Cr}$ and $\mathrm{Zr}$ were still higher than the target for all cases. Na was $>10 \%$ different than the target for the $24 \mathrm{~K}$ and $20 \mathrm{~K}$ case. Si was higher for the $24 \mathrm{~K}$ case than in the analyzed adjusted sludge but can be explained by the addition of sand. All titration results decreased as would be expected from dilution from the additional trimming. The $\mathrm{pH}$ for the $24 \mathrm{~K}$ case receipt samples seemed very low and could be due to the higher concentration of nitrate relative to nitrite in the sludge. None of these changes were considered significant enough to affect the results of testing.

The original acid calculation was performed using the "sludge" analysis data given in Tables A -3 and A -4 and projections of the SRAT starting mass, sample masses, and dewater masses. The receipt data in Table A -5 was not used, since it was not available until after the run started. Table 2 provides the data, along with the assumed reaction conversions and destructions. Most data was based on the sludge analyses given in Tables A - 3 and A - 4. When necessary, the input parameter was adjusted to account for the trim chemicals that needed to be added.

Table 2: Pre-Run Measured Inputs and Assumptions for Acid Calculation

\begin{tabular}{|c|c|c|c|c|c|c|}
\hline Input Parameter & $\begin{array}{c}\text { Case 6b } \\
\text { SB3A-14 }\end{array}$ & $\begin{array}{c}\text { Case 6b } \\
\text { SB3A-15 and } \\
\text { SB3A-16 }\end{array}$ & \multicolumn{2}{|c|}{$\begin{array}{c}\text { 20K Case } \\
\text { SB3A-17 and } \\
\text { SB3A-18 }\end{array}$} & \multicolumn{2}{|c|}{$\begin{array}{c}\text { 24K Case } \\
\text { SB3A-19 and } \\
\text { SB3A-20 }\end{array}$} \\
\hline Nitrite (mg/kg) & 25,100 & 27,100 & \multicolumn{2}{|c|}{21,500} & \multicolumn{2}{|c|}{27,000} \\
\hline Nitrate $(\mathrm{mg} / \mathrm{kg})$ & 19,420 & 21,100 & \multicolumn{2}{|c|}{15,900} & \multicolumn{2}{|c|}{23,200} \\
\hline Oxalate (mg/kg) & 1875 & 1875 & \multicolumn{2}{|c|}{2680} & \multicolumn{2}{|c|}{3000} \\
\hline TIC (mg/kg) & 1100 & 949 & \multicolumn{2}{|c|}{800} & \multicolumn{2}{|c|}{800} \\
\hline Hydroxide - Base Equivalents (M) & 0.643 & 0.698 & \multicolumn{2}{|c|}{0.476} & \multicolumn{2}{|c|}{0.626} \\
\hline Mn (wt\% in dried solids) & 3.17 & 3.17 & \multicolumn{2}{|c|}{3.49} & \multicolumn{2}{|c|}{3.24} \\
\hline Total Solids (wt\%) & 21.5 & 22.6 & \multicolumn{2}{|c|}{21.6} & \multicolumn{2}{|c|}{22.4} \\
\hline Sludge Density (g/ml) & 1.17 & 1.18 & \multicolumn{2}{|c|}{1.20} & \multicolumn{2}{|c|}{$1.21^{1}$} \\
\hline Formate destruction & $20 \%$ & $10 \%$ & $24 \%$ & $29 \%$ & $22 \%$ & $21 \%$ \\
\hline Oxalate destruction & $10 \%$ & $0 \%$ & \multicolumn{2}{|c|}{$5 \%$} & \multicolumn{2}{|c|}{$5 \%$} \\
\hline Nitrite to Nitrate Conversion & $40 \%$ & $40 \%$ & $38 \%$ & $45 \%$ & $36 \%$ & $40 \%$ \\
\hline Receipt Mass (g) & 2577 & 2750 & \multicolumn{2}{|c|}{2800} & \multicolumn{2}{|c|}{2800} \\
\hline Acid Stoichiometry & $170 \%$ & $160 \%$ & $130 \%$ & $155 \%$ & $121.1 \%$ & $150.1 \%$ \\
\hline Redox Target $^{2}$ & 0.19 & 0.2 & 0.177 & 0.189 & 0.133 & 0.114 \\
\hline Moles of Acid/Liter of Slurry & 2.568 & 2.401 & 1.549 & 1.847 & 1.738 & 2.154 \\
\hline
\end{tabular}

\subsection{SRAT and SME Processing}

As stated in Section 3.2, most of the SRAT/SME runs for a target endpoint case were performed simultaneously in two different hoods at the ACTL in the 4-liter vessels. The SRAT cycles were initiated after the receipt samples were pulled. Table A -2 gives the pertinent operating parameters for the SRAT/SME cycles. Where applicable, nitric acid was added first and then formic acid. For three of the runs, no nitric acid was used. The $20 \mathrm{~K}$ case did not require any nitric acid at the 0.20 redox target (i.e., due to the high nitrite and nitrate concentrations, only formic acid could be added to meet the target). After the completion of acid addition, the vessel was ramped to boiling. Once boiling was initiated, the SRAT contents were dewatered/concentrated to bring the sludge to the target solids concentration and then the SRAT was refluxed for 12 hours. Run SB3A-19 had a slightly different operating strategy then the other runs. This was done to provide an opportunity to find the minimum acid amount more definitively and to assess the impact of additional reflux time on nitrite destruction. Therefore, a 12, 15, and 18 hour sample was pulled for nitrite measurement. When it was determined that nitrite was not destroyed, additional acid was added and the contents were refluxed for 3 hours before pulling another check sample. After the second remediation where high nitrite was detected, it was decided to boil for an additional 15 hours and then check the nitrite. Therefore, the total reflux was $\sim 39$ hours. The strategy will be discussed in more detail later in this section.

SME cycles were started immediately after the completion of the SRAT cycles. No canister decontamination additions were simulated during this set of SME cycles to try to be more conservative for hydrogen generation. Therefore, the 
addition of the frit/acid/water served as the starting point for the SME cycle. The frit and associated formic acid and water were added over 3 additions. Frit 202 was used in all runs targeting a waste loading of $38 \mathrm{wt} \%$. The acid and water addition amounts were based on the DWPF target frit slurry addition method (i.e., $1.5 \mathrm{wt} \%$ formic in $50 \mathrm{wt} \%$ solid solution). After the first two frit additions, the SME was concentrated to remove the equivalent mass of water and formic added. For the final frit addition, the SME was concentrated with a goal of reaching a final solids content of 50 $\mathrm{wt} \%$. As stated in section 3.2, additional reflux was performed in some of the runs to help ascertain the peak hydrogen generation. The SME cycle was halted during SB3A-14 since the hydrogen limit was exceeded early in the run. For SB3A-15, water in the air line caused a pressurization of the vessel so the SME could not be completed.

Mass balances of the components added and removed from the vessels are given as Tables A - 6 through 12 in Appendix A. Overall mass balance closure was good for the runs and was within $100-200 \mathrm{~g}$ on a mass basis. This is consistent with other SB3 simulant runs.[3,4,5] The bulk of the material balance deficit was probably contained in the offgas non-condensable species $\left(\mathrm{CO}_{2}, \mathrm{NO}, \mathrm{NO}_{2}, \mathrm{~N}_{2} \mathrm{O}\right.$, and $\left.\mathrm{H}_{2}\right)$. The remainder was measurement error and lost water vapor.

Mixing and heating of the slurries during the SRAT/SME cycles were not an issue. For the most part, no problems with foaming or processing of the slurries were evident. In Run SB3A-18, some foaming was seen during formic acid addition. The foam was easily mitigated with an addition of $100 \mathrm{ppm}$ of antifoam. No additional antifoam had been added to cover the DWPF amount added between acid additions. No other problems were seen during this run or other runs.

The $\mathrm{pH}$ was measured throughout the runs. Figures 2 and 3 are plots of the measured $\mathrm{pH}$ during the SRAT and SME cycles. The plots are broken into the SRAT and SME cycles for clarity. Figure 2 is shown relative to the end of acid addition, while the SME data is shown relative to the start of the SME cycle since SB3A-19 had a very long SRAT reflux. For the SRAT, the end of acid addition for SB3A-19 was considered the end of the first acid addition.

Figure 2: pH Plots during SRAT Processing

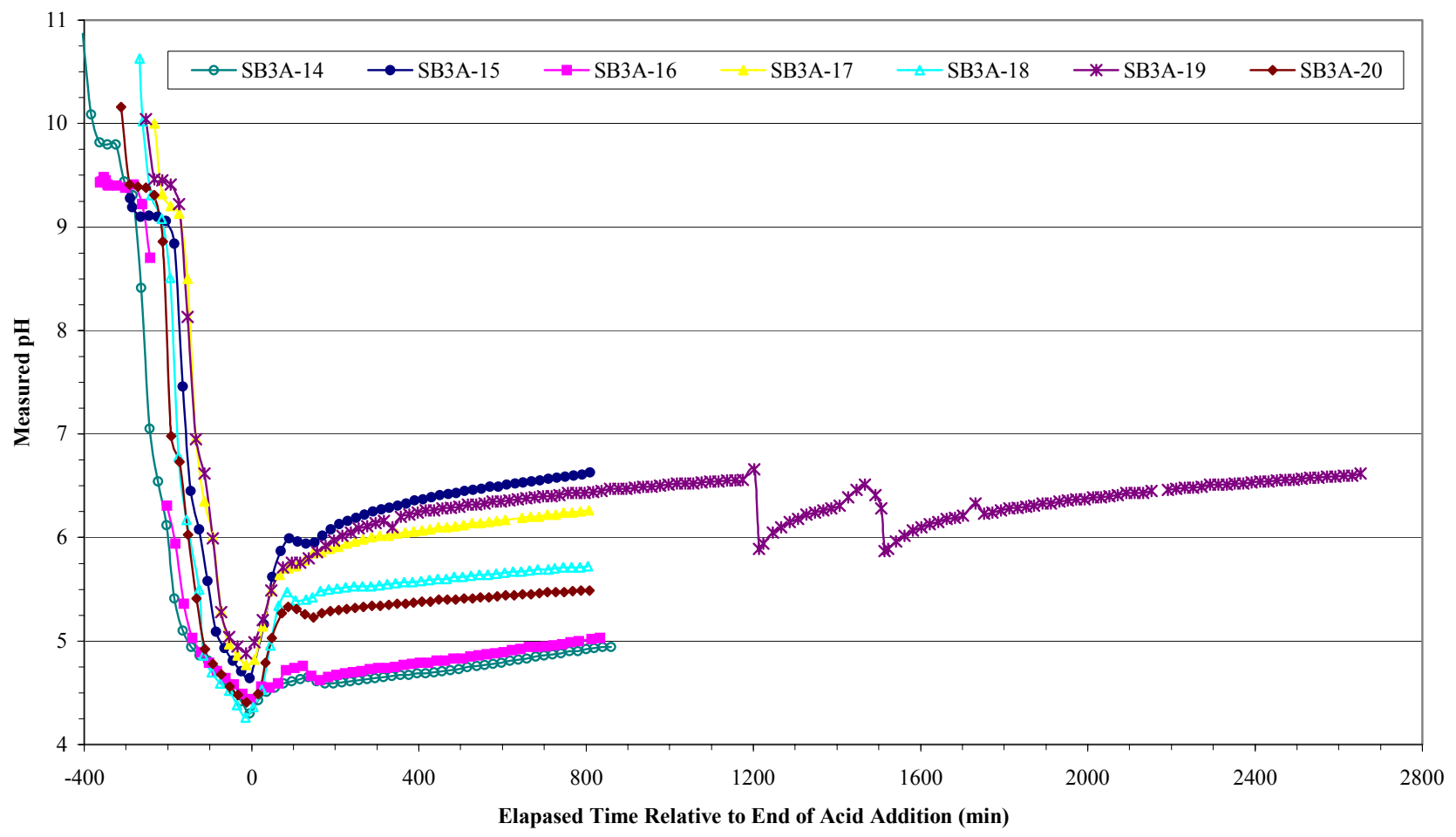


Figure 3: pH Plots during SME Processing

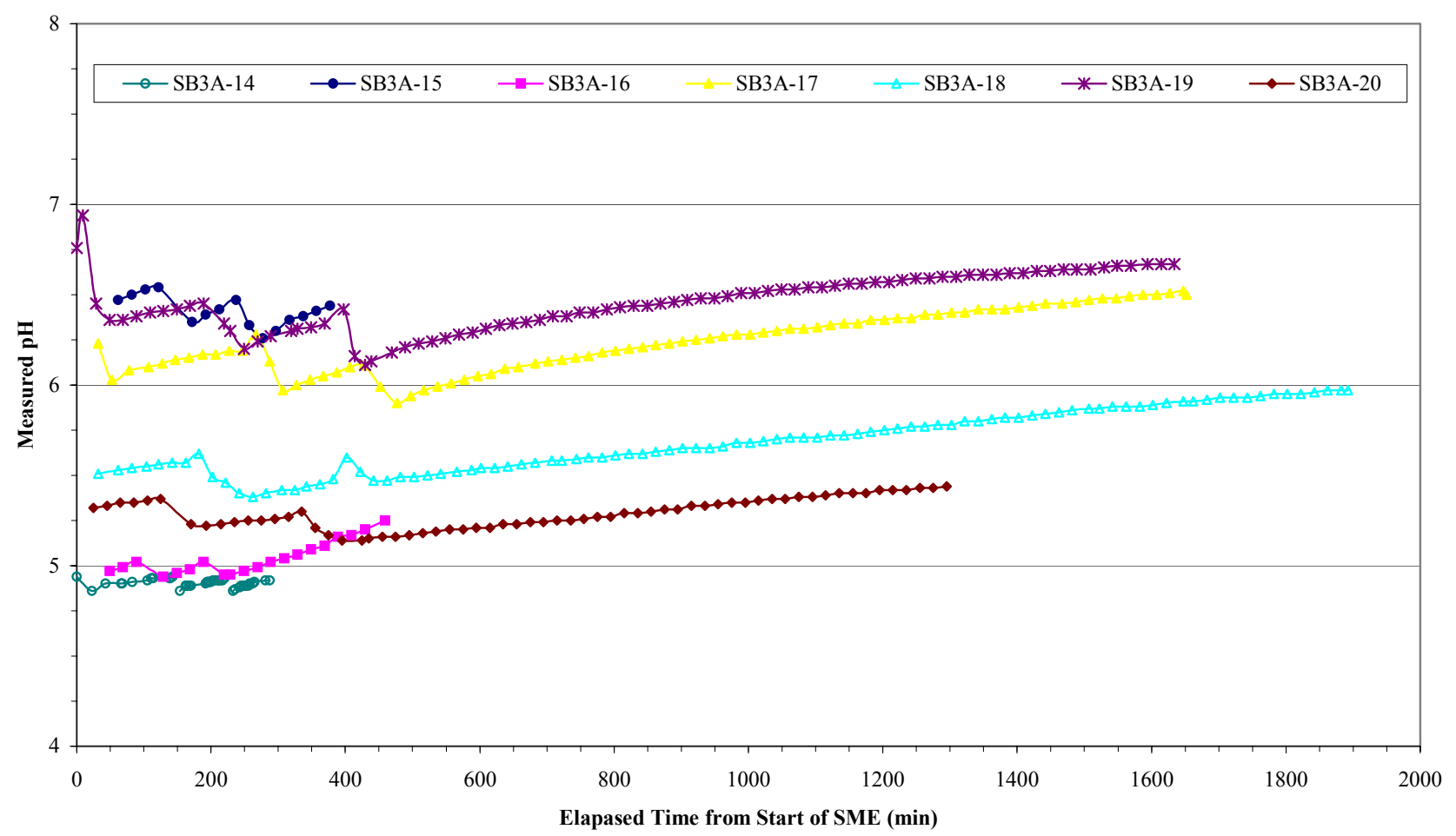

The $\mathrm{pH}$ profiles during acid addition were relatively similar. As expected, the runs at higher acid (Runs SB3A-14, -16 , -18 , and -20 ) had lower minimum and ending pHs during the SRAT and SME. The actual measured values are given in Table $\mathrm{A}-2$. All of the runs appeared to be consuming some amount of acid throughout refluxing. The $\mathrm{pH}$ fluctuated throughout the SME cycles due to the frit/water/formic additions. The $\mathrm{pH}$ also continued to rise throughout the SME cycles indicating acid was still being consumed.

As stated earlier, samples of the slurries were taken throughout processing to monitor the chemical reactions. However, only a limited number of the samples were analyzed. No samples were analyzed from SB3A-15. The sample results for select samples, along with the times the samples were removed relative to the end of formic acid addition, are given in Table 3. The following system was used for the Sample IDs in the runs:

- the "-1" samples were taken after SRAT dewatering was complete,

- the "-6" samples were taken 6 hours into reflux;

- the "-12" samples were taken 12 hours into reflux;

- the "- 18 " samples were taken 18 hours into reflux;

- the "Remediated" sample was taken at the end of the first additional acid addition and 3 hours of reflux;

- the "Remediated 2" sample was taken at the end of the second additional acid addition and 3 hours of reflux;

- the " 6 am" sample was taken 14 hours into the second remediation reflux. 
Table 3: In-Process Slurry Anion Concentrations Based on Weighted Dilutions (mg/Kg)

\begin{tabular}{|c|c|c|c|c|c|c|c|}
\hline Case & Run ID & Sample ID & $\begin{array}{l}\text { Time Relative to } \\
\text { End of Acid } \\
\text { Addition (min) }\end{array}$ & Nitrite & Nitrate & Formate & Oxalate \\
\hline \multirow{2}{*}{$\mathbf{6 b}$} & SB3A-14 & SRAT IC-12 & 856 & $<108$ & 49040 & 72532 & 2274 \\
\hline & SB3A-16 & SRAT IC-12 & 848 & $<110$ & 44648 & 65213 & 2551 \\
\hline \multirow{4}{*}{$\begin{array}{c}20 K \\
\text { nitrite }\end{array}$} & \multirow{2}{*}{ SB3A-17 } & SRAT IC-1 & 84 & 7616 & 22825 & 49329 & 3040 \\
\hline & & SRAT IC-6 & 444 & 3139 & 26305 & 49795 & 2836 \\
\hline & \multirow{2}{*}{ SB3A-18 } & SRAT IC-1 & 89 & 453 & 26752 & 59244 & 2805 \\
\hline & & SRAT IC-6 & 449 & $<109$ & 28260 & 58694 & 2848 \\
\hline \multirow{6}{*}{$\begin{array}{c}24 K \\
\text { nitrite }\end{array}$} & \multirow{5}{*}{ SB3A-19 } & SRAT IC-12 & 812 & 5233 & 30744 & 54074 & 2202 \\
\hline & & SRAT IC-18 & 1172 & 4343 & 31285 & 54366 & 2133 \\
\hline & & Remediated & 1464 & 3820 & 31522 & 55929 & 2091 \\
\hline & & Remediated 2 & 1763 & 3177 & 30794 & 57018 & 2035 \\
\hline & & $6 \mathrm{am}$ & 2527 & 1845 & 32386 & 56323 & 1950 \\
\hline & SB3A-20 & SRAT IC-6 & 458 & $<548$ & 40733 & 61425 & 1983 \\
\hline
\end{tabular}

Note: Performed on samples removed during processing that were quenched with $1 \mathrm{~N} \mathrm{NaOH}$. Data presents results from single analysis corrected for $\mathrm{NaOH}$ quench. No samples from SB3A-15 were analyzed.

The data was used to help monitor reactions and to provide duplicate analyses of the anions in the products. A large difference in nitrite destruction behavior at the two different acid levels is seen for the $20 \mathrm{~K}$ case. With dewater completion (i.e., sample IC-1), nitrite had been destroyed to less than $1000 \mathrm{mg} / \mathrm{kg}$ for SB3A-18, while SB3A-17 still had a significant amount of nitrite. The same behavior is seen in the $24 \mathrm{~K}$ nitrite case, where the 6 hour sample for SB3A-20 was below the detection limit, while SB3A-19 still had significant nitrite after additional acid and reflux time.

The data for SB3A-19 was plotted to track nitrite destruction. This plot is provided as Figure B - 1 in Appendix B. The plot shows that the effect of acid addition was not immediate, but was helpful in destroying additional nitrite. The additional boiling time was also effective. The plot shows moles of nitrite remaining so moles of nitrite destroyed per addition can be easily calculated. The target is based on $1000 \mathrm{mg} / \mathrm{kg}$ of nitrite for the estimated SRAT product mass.

As mentioned in Section 4.0, hydrogen, oxygen, nitrogen, carbon dioxide, and nitrous oxide were measured throughout the runs using GCs. Figures B - 2 through B - 8 of Appendix B give the gas composition data measured by the GC for the individual SRAT runs. During review of this report, it was learned that DWPF purge rates had been increased and the lower limit for the SRAT was now $230 \mathrm{scfm}$ instead of the $188 \mathrm{scfm}$ used in the ITS studies for scaling purposes. This would mean that the values reported here are conservative for the DWPF actual purge rates. Run SB3A-14 had a significant hydrogen peak, $\sim 0.8$ volume $\%$, at the end of acid addition. Run SB3A-16 was the only other run in this phase of testing to exhibit a large hydrogen peak at the end of acid addition, and it was $\sim 0.3$ volume $\%$. In addition to the peaks of hydrogen at the end of acid addition, increased hydrogen generation was seen $\sim 6$ hours into boiling and then the volume concentration remained relatively constant for SB3A-14 and slightly increased for SB3A-16. Oxygen behavior was very different during this phase of testing with total oxygen depletion occurring during most runs in formic acid addition. The oxygen level gradually returned to normal levels after the end of acid addition. During the time of oxygen depletion, carbon dioxide and nitrous oxide both peaked in concentration. In the lower acid runs SB3A15, SB3A-17, and SB3A-19, this behavior also occurred but was delayed until almost the end of acid addition for SB3A-15 and SB3A-19 and did not reach zero for SB3A-17. Peaks of carbon dioxide and oxygen were seen in some of the runs at the end of acid addition, which was likely due to the opening of the system to remove the acid pump and add antifoam. For the Case $6 \mathrm{~b}$ and the $24 \mathrm{~K}$ case runs, small amounts of carbon dioxide continued to be generated throughout the runs. Most of the runs also had a large peak of carbon dioxide $\sim 2$ hours before formic acid addition was completed. An additional nitrous oxide peak was seen at the end of dewater for the Case $6 \mathrm{~b}$ runs, the high acid $20 \mathrm{~K}$ case run (SB3A-18), and the $24 \mathrm{~K}$ case runs, but was at lower concentrations than the one seen towards the end of acid addition. The presence of the two nitrous peaks was consistent with earlier SB3 simulant SRAT runs.[3,4,5] Figure B 7 also shows the GC data for the remediation that was performed on the SRAT product to attempt to destroy the additional nitrite. Very small peaks of nitrous oxide and carbon dioxide were seen during the remediation acid additions. 
Figure 4 provides a plot of the hydrogen data for the runs with appreciable SRAT hydrogen. No hydrogen was detected in the low acid runs (SB3A-15, SB3A-17, and SB3A-19). The plot compares hydrogen generation for the runs on a DWPF scale in pounds per hour. The scale for each run varied slightly and the actual scale factors are shown in Table A -2 based on an assumed DWPF 6,000 gallon volume of fresh sludge without a heel. Run SB3A-14 had the most significant hydrogen peak, and was $\sim 80 \%$ of the DWPF SRAT limit when scaled to the DWPF volume. It occurred at $\sim 50$ minutes after the end of acid addition. A similar but much smaller peak was also seen $\sim 50$ minutes after the end of formic acid addition for Run SB3A-16. The continual rise in hydrogen generation rate is easily seen in these plots $\sim 6$ hours into boiling. For Run SB3A-16, the peak at the end of the SRAT was similar to the level seen after formic acid addition. Very small amounts of hydrogen were generated starting after the end of dewater for Runs SB3A-18 and SB3A-20. The hydrogen remained at this level throughout the remainder of reflux.

Figure 4: Hydrogen Generation on a DWPF Scale for SRAT

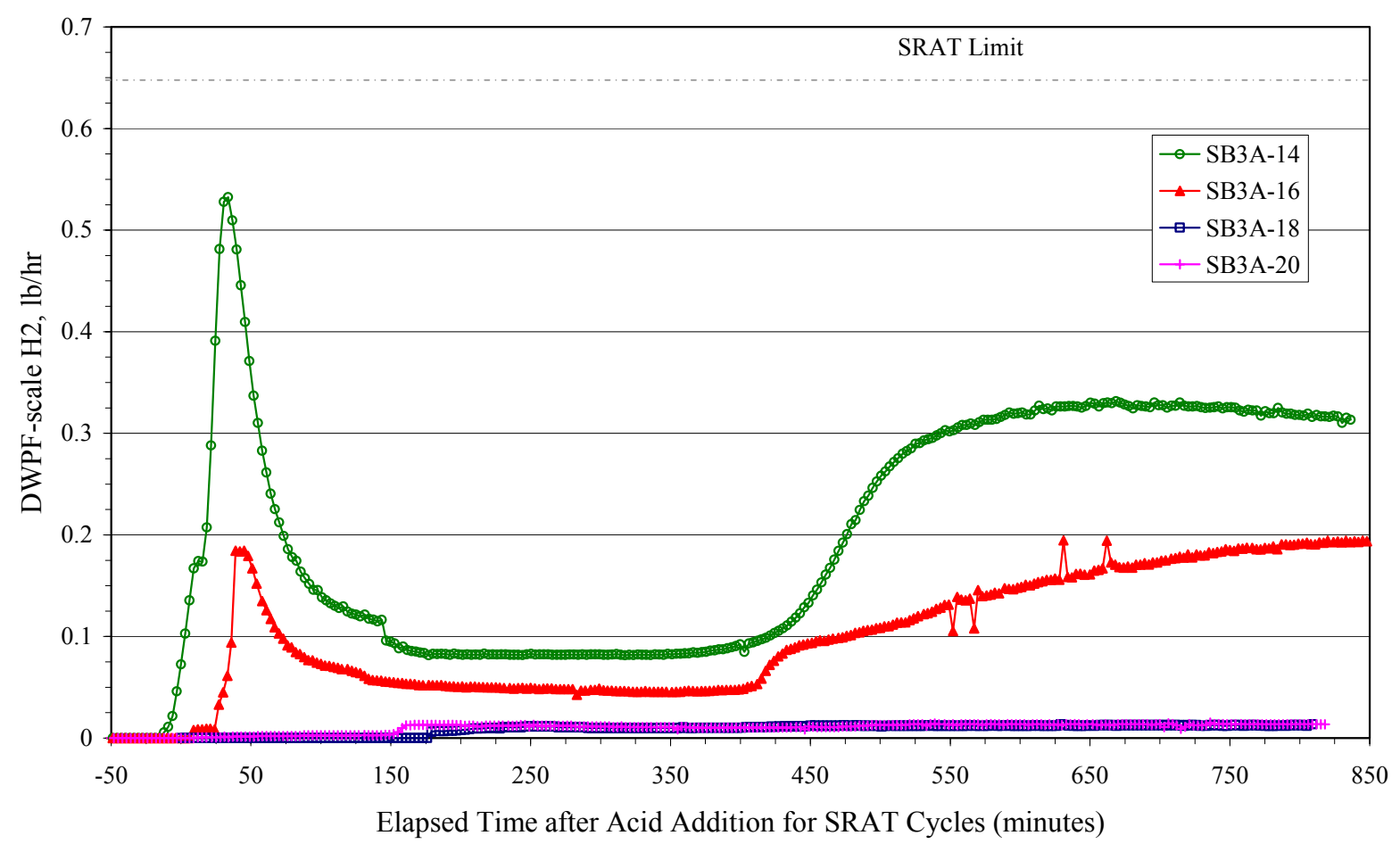

Figures B - 9 through B - 15 of Appendix B give the gas composition data measured for the SME cycles. Once again, this data was based on a purge rate lower than what DWPF is actually using. DWPF's lower limit is $74 \mathrm{scfm}$ and the runs used $66 \mathrm{scfm}$ to scale the purge rates. Data was not corrected and would be conservative for the DWPF rates. Figure 5 provides a plot of the hydrogen data for the SME cycles. SME hydrogen fluctuated with frit additions in the SME cycle, where hydrogen would drop as the material was added and the vessel cooled and then would peak again during dewater. However, unlike with previous SB3 SME cycles, the hydrogen in the high acid Case 6b runs did not continue to decrease over time or level off after peaking. An instantaneous decrease occurred at the point of frit addition, but then hydrogen slowly started to rise again until another frit addition was performed. As shown in Figure 5, the DWPF hydrogen limit was exceeded early in Run SB3A-14 and continued to rise throughout the run, so the cycle was halted before the completion of concentration. Concurrent with the hydrogen peaking, carbon dioxide and nitrous oxide also peaked. After the peaks, the carbon dioxide and nitrous oxide levels remained relatively constant. No hydrogen was seen in Runs SB3A-15, SB3A-17, or SB3A-19, but the nitrous oxide and carbon dioxide peaks were seen with each frit addition. Runs SB3A-18 and SB3A-20 had similar behavior to the Case $6 \mathrm{~b}$ runs, but were at much lower concentrations. The hydrogen was not rising very sharply in Run SB3A-18, while a steeper generation rate was seen for Run SB3A-20 but it only reached about $15 \%$ of the SME limit. The SME GC data for Run SB3A-15 reveal some of the problems that started occurring at the end of the run, i.e., water in the lines and pressure problems. Thus, this run was also stopped before concentration or the SME cycle was completed. It is believed that the hydrogen was attributed to 
the water line problem and not actual hydrogen evolution from the noble metals. The SME cycle GC data for oxygen in Run SB3A-19 apparently was not integrated correctly since it was indicating $\sim 68 \%$ oxygen present in the gas with $\sim 75 \%$ nitrogen already present. Therefore, the oxygen data was not included in Figure B - 14.

Figure 5: Hydrogen Generation on a DWPF Scale for SME

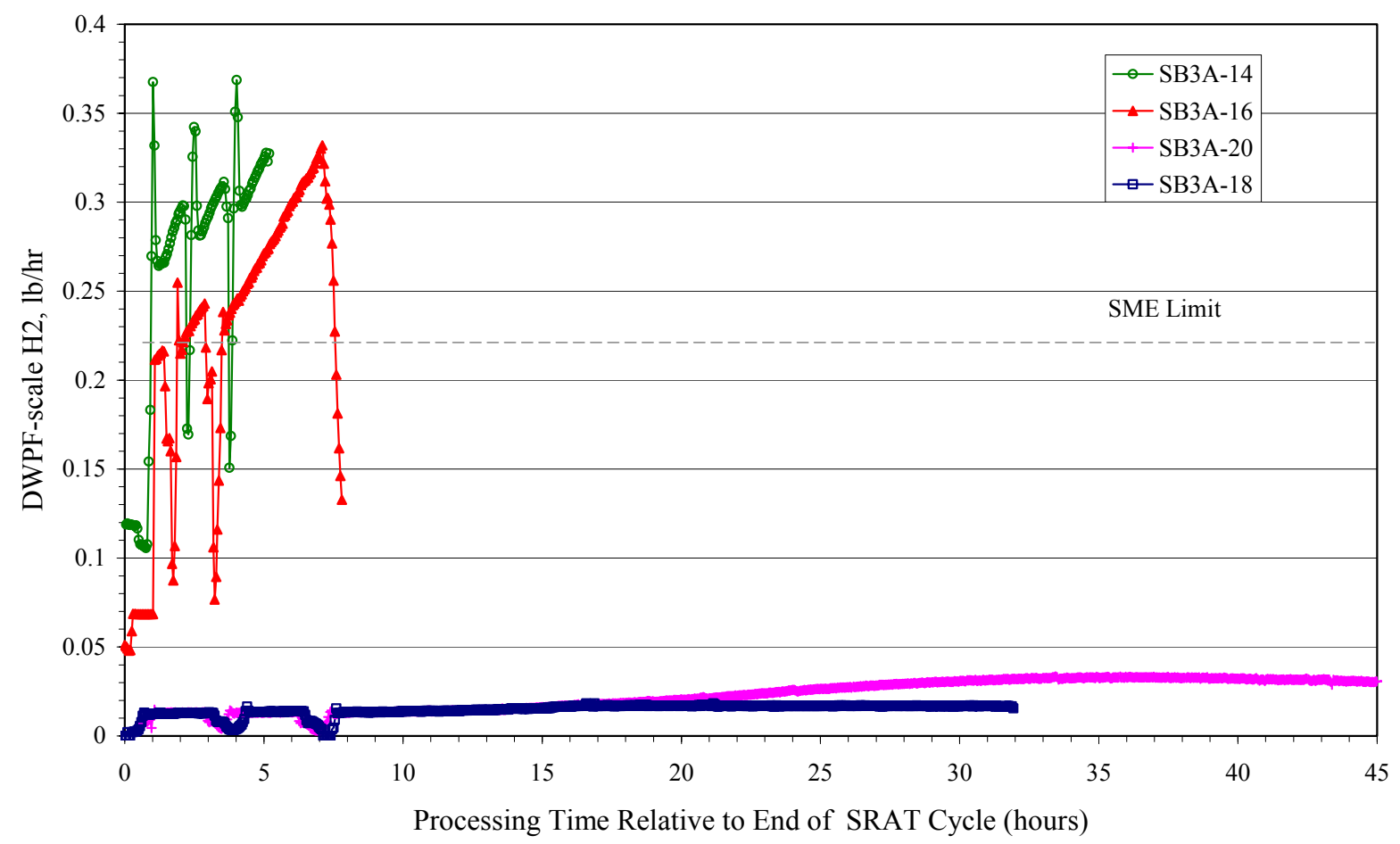

The peak hydrogen generation on both a DWPF scale in pounds/hour and on a volume percent basis for each run is given in Table 4. Once again, these values were based on purge rates lower than the current DWPF purge rates and are therefore conservative estimations (i.e., results would have to be multiplied by $\sim 0.76$ for the SRAT and $\sim 0.92$ for the SME). The peak volume percent carbon dioxide and nitrous oxide concentrations are also given. A total mass of hydrogen, carbon dioxide, and nitrous oxide generated was calculated by integrating the mass-flow rate for each gas over the time of the SRAT or SME cycle. A flow-rate was calculated for each GC reading, and then the total mass of gas evolved was determined by integrating the instantaneous flow-rates over the time period of the cycle. Simpson's rule was used to perform the numerical integration. 
Table 4: Peak Volume \% and Mass of Hydrogen, Carbon Dioxide, and Nitrous Oxide Gases Generated

\begin{tabular}{|c|c|c|c|c|c|c|c|c|}
\hline \multirow{2}{*}{ Case } & \multirow{2}{*}{$\begin{array}{l}\text { Run and } \\
\text { Product ID }\end{array}$} & \multirow{2}{*}{$\begin{array}{c}\text { Peak } \mathrm{H}_{2} \text { on } \\
\text { DWPF Scale } \\
(\mathrm{lbs} / \mathrm{hr})^{3}\end{array}$} & \multicolumn{3}{|c|}{ Peak Volume $\%^{3}$} & \multicolumn{3}{|c|}{ Total Mass Generated (g) ${ }^{3}$} \\
\hline & & & $\mathrm{H}_{2}$ & $\mathrm{CO}_{2}$ & $\mathbf{N}_{2} \mathbf{O}$ & $\mathbf{H}_{2}$ & $\mathrm{CO}_{2}$ & $\mathrm{~N}_{2} \mathrm{O}$ \\
\hline \multirow{6}{*}{$6 \mathrm{~b}$} & SB3A-14 SRAT & 0.53 & 0.799 & 33.5 & 0.397 & 0.125 & 82.4 & 0.686 \\
\hline & SB3A-14 SME $^{1}$ & 0.369 & 1.28 & 6.22 & 0.040 & $\mathrm{~N} / \mathrm{A}$ & N/A & N/A \\
\hline & SB3A-15 SRAT & $\mathrm{N} / \mathrm{A}$ & $\mathrm{N} / \mathrm{A}$ & 22.4 & 1.62 & $\mathrm{~N} / \mathrm{A}$ & 61.7 & 3.11 \\
\hline & SB3A-15 SME $^{1}$ & N/A & 0.040 & 3.73 & 0.107 & N/A & N/A & N/A \\
\hline & SB3A-16 SRAT & 0.19 & 0.294 & 24.4 & 1.57 & 0.068 & 67.6 & 2.65 \\
\hline & SB3A-16 SME & 0.332 & 1.25 & 8.30 & 0.42 & 0.078 & 7.65 & 0.019 \\
\hline \multirow{4}{*}{$\begin{array}{c}20 K \\
\text { nitrite }\end{array}$} & SB3A-17 SRAT & N/A & N/A & 16.6 & 1.18 & N/A & 33.0 & 1.43 \\
\hline & SB3A-17 SME & N/A & $\mathrm{N} / \mathrm{A}$ & 1.93 & 0.047 & $\mathrm{~N} / \mathrm{A}$ & 2.99 & 0.135 \\
\hline & SB3A-18 SRAT & 0.014 & 0.020 & 22.4 & 1.91 & 0.006 & 54.3 & 2.47 \\
\hline & SB3A-18 SME & 0.018 & 0.067 & 1.98 & 0.142 & 0.020 & 5.32 & 0.470 \\
\hline \multirow{4}{*}{$\begin{array}{c}24 K \\
\text { nitrite }\end{array}$} & SB3A-19 SRAT $^{2}$ & N/A & $\mathrm{N} / \mathrm{A}$ & 37.3 & 1.30 & N/A & $49.7 / 5.82$ & $2.96 / 0.308$ \\
\hline & SB3A-19 SME & N/A & $\mathrm{N} / \mathrm{A}$ & 2.28 & 0.059 & $\mathrm{~N} / \mathrm{A}$ & 4.00 & 0.258 \\
\hline & SB3A-20 SRAT & 0.015 & 0.022 & 23.1 & 2.43 & 0.007 & 52.7 & 3.31 \\
\hline & SB3A-20 SME & 0.033 & 0.127 & 1.35 & 0.094 & 0.047 & 8.08 & 0.292 \\
\hline
\end{tabular}

${ }^{2}$ Second value represents the additional mass of gas generated during the SRAT remediation.

${ }^{3}$ All values are based on scaled SRAT purge rate of $188 \mathrm{scfm}$ and SME purge rate of $66 \mathrm{scfm}$

The hydrogen data reported in Table 4 reiterate the problems seen with hydrogen during the SME cycles for the runs. Interestingly enough, even though Run SB3A-20 was only within $15 \%$ of the SME limit, its total mass of hydrogen generated was approximately half of the amount generated in SB3A-16; yet, SB3A-16 exceeded the SME limit. Run SB3A-19 had the largest peak volume percent carbon dioxide in the SRAT, while SB3A-16 had the largest carbon dioxide peak in the SME cycle. For the $20 \mathrm{~K}$ and $24 \mathrm{~K}$ case runs, the peak volume percent nitrous oxide was greater in the run with the higher level of acid. This behavior was not seen in the Case $6 \mathrm{~b}$ runs, and the data may indicate that some of the nitrous oxide in SB3A-14 may not have been detected. The total mass of the gases generated also corresponded fairly well with the level of acid used, with higher acid runs creating more gases as would be anticipated.

\subsection{SRAT Product Characterization}

The SRAT product from each run was characterized for the anion concentration, cation concentration, solids content, density, and $\mathrm{pH}$. The product anion concentration for each run is given in Table 5. Runs SB3A-17 and SB3A-19 did not meet the existing $<1000 \mathrm{mg} / \mathrm{kg}$ nitrite limit; however, they were successful with regards to the other criteria especially since no hydrogen was generated.

Table 5: SRAT Product Anion Concentration (mg/kg)

\begin{tabular}{|c|c|c|c|c|c|c|c|}
\hline Anion & SB3A-14 & SB3A-15 & SB3A-16 & SB3A-17* & SB3A-18* & SB3A-19* & SB3A-20* \\
\hline Nitrite & $<100$ & 747 & $<100$ & 1885 & $<100$ & 1635 & $<500$ \\
\hline Nitrate & 48,350 & 35,900 & 47,000 & 26,850 & 28,550 & 31,950 & 39,700 \\
\hline Formate & 70,300 & 55,500 & 66,000 & 50,100 & 59,200 & 57,000 & 61,300 \\
\hline Oxalate & 2160 & 2060 & 2700 & 2045 & 2430 & 1480 & 1785 \\
\hline
\end{tabular}

Note: Analyses performed on weighted dilution of samples. *Results represent an average of two measurements.

The results in Table A - 5, Table 5, and the mass balance tables in Appendix A, along with the known addition amounts of nitric acid and formic acid, were used to estimate the destruction that occurred during the SRAT cycles. The SRAT receipt numbers are based on the analytical data in Table A - 5 and the estimated mass that was in the vessel at the start of the runs. The destruction results were adjusted for the samples that were pulled during processing, and the samples' associated anions were considered removed from the system from a possible reaction standpoint. Since not all of the samples were measured, estimates of the anion masses removed were performed. Three methods were used to estimate the anions removed with the samples, which were as follows: 
1. All samples were assumed to be at the initial concentration (including acid, as applicable) or the sample analyzed immediately before it (e.g., a "-3" sample would be considered at same concentration as a measured "-1" sample see results in Table 3),

2. An average concentration was calculated bracketing the data results (e.g., a "-3" sample was assumed to be present at the average concentration of the "-1" and "-6" sample); and

3. The initial concentration at the end of acid addition was used for the first sample ("- 0 "), then all others were assumed at the end analysis or product concentration unless interim sample results were available.

An average removed sample mass was then calculated and is presented in Table 6 . The percent destruction, creation, or conversion also represents the averages from the calculations. The numbers given in Table 6 convey destruction based on the receipt and product parameters. They do not attempt to estimate the effect that the removed anions would have had on the system or to incorporate other possible reactions occurring during processing. Since the SRAT product mass was not weighed, estimates for the associated SRAT product mass had to be made. This was done by assuming that $3 \%$ of the sludge receipt mass was lost during SRAT processing. The 3\% loss number was based on the earlier phases of SB3 testing [2,3,4], and it is realized that differences in loss may have occurred due to the changes in the amounts of acid used. The product estimate was also adjusted for the FAVC material removed and the MWWT loss, when measured, at the end of the SRAT.

Table 6: Destruction of Nitrate, Formate, and Oxalate - SRAT Receipt Relative to SRAT Product

\begin{tabular}{|c|c|c|c|c|c|c|c|}
\hline Parameter & $\begin{array}{c}\text { SB3A- } \\
14\end{array}$ & $\begin{array}{c}\text { SB3A- } \\
15\end{array}$ & $\begin{array}{c}\text { SB3A- } \\
16\end{array}$ & $\begin{array}{c}\text { SB3A- } \\
17\end{array}$ & $\begin{array}{c}\text { SB3A- } \\
18\end{array}$ & $\begin{array}{c}\text { SB3A- } \\
19\end{array}$ & $\begin{array}{c}\text { SB3A- } \\
20\end{array}$ \\
\hline 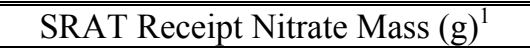 & (53.32 & 54.23 & 53.69 & 44.56 & 44.80 & 59.36 & 58.80 \\
\hline Nitrate Added (g) & 23.84 & 6.234 & 26.20 & N/A & N/A & N/A & 12.98 \\
\hline Nitrate Removed in Samples $(\mathrm{g})^{2}$ & 2.665 & 2.184 & 2.496 & 1.714 & 1.912 & 3.978 & 2.517 \\
\hline SRAT Product Nitrate Mass $(\mathrm{g})^{3}$ & 120.7 & 94.42 & 125.0 & 72.23 & 76.65 & 81.68 & 105.2 \\
\hline \% Nitrate Created in SRAT ${ }^{4}$ & 62.0 & 62.0 & 61.5 & 68.6 & 78.7 & 47.5 & 56.9 \\
\hline Nitrite to Nitrate Conversion $(\%)^{5}$ & 49.1 & 39.7 & 49.3 & 40.4 & 43.6 & 31.1 & 40.5 \\
\hline Formate Added in SRAT (g) & 237.2 & 192.2 & 232.8 & 162.7 & 194.0 & 192.9 & 214.9 \\
\hline Formate Removed in Samples $(\mathrm{g})^{2}$ & 5.399 & 4.666 & 5.108 & 3.611 & 4.419 & 7.880 & 4.683 \\
\hline SRAT Product Formate Mass $(\mathrm{g})^{3}$ & 175.5 & 146.0 & 175.5 & 134.8 & 158.9 & 145.7 & 162.4 \\
\hline \% Formate Destruction in SRAT ${ }^{4}$ & 24.3 & 22.2 & 22.9 & 15.3 & 16.1 & 21.2 & 22.7 \\
\hline SRAT Receipt Oxalate Mass (g) ${ }^{1}$ & 5.516 & 10.378 & 9.085 & 7.360 & 7.974 & 9.464 & 8.372 \\
\hline Oxalate Removed in Samples $(\mathrm{g})^{2}$ & 0.140 & 0.216 & 0.200 & 0.189 & 0.199 & 0.329 & 0.159 \\
\hline SRAT Product Oxalate Mass (g) & 5.393 & 5.418 & 7.180 & 5.501 & 6.524 & 3.783 & 4.730 \\
\hline \% Oxalate Destruction in SRAT ${ }^{4}$ & -0.30 & 46.7 & 19.2 & 23.3 & 16.1 & 58.6 & 42.4 \\
\hline
\end{tabular}

Nitrate creation was very high in all of the runs due to the relatively high nitrite to nitrate conversions. This is much greater than what was seen in the earlier SB3 simulant runs with oxalate, where creation was very minimal, as was conversion. $[2,4,3]$ The high numbers are probably due to the much higher than normal starting nitrite and nitrate, which would have continued to react during refluxing of the system. Formate destruction, on the other hand, was equivalent to destruction seen in previous sludge batch testing [6], but is higher than what was seen in other SB3 testing.[2] Unlike previous testing, the destruction results did not appear to be greatly impacted by the acid addition level.[2,3,5] The formate destructions are similar to those assumed in the original acid calculations and to those used in the current DWPF acid calculations. The $20 \mathrm{~K}$ case had the lowest formate destruction. Oxalate destruction varied greatly from run to run with each case. This was likely due to the low quantity present. Given a pair of tests within a case, oxalate destruction was greater in runs with less acid.

As mentioned in Section 4.0, the SRAT products were calcined at $1100^{\circ} \mathrm{C}$ in order to prepare them for cation analyses. The oxides detected in the calcined solids are given as Table 7 . 
Table 7: SRAT Product Results (Calcined Solids Wt\%)

\begin{tabular}{|c|c|c|c|c|c|c|c|}
\hline \multirow{2}{*}{ Oxide } & \multicolumn{3}{|c|}{ Case 6b } & \multicolumn{2}{|c|}{ 20K Nitrite Case } & \multicolumn{2}{|c|}{ 24K Nitrite Case } \\
\hline & SB3A-14 & SB3A-15 & SB3A-16 & SB3A-17 & SB3A-18 & SB3A-19 & SB3A-20 \\
\hline $\mathrm{Al}_{2} \mathrm{O}_{3}$ & 16.1 & 15.9 & 16.2 & 17.9 & 17.7 & 17.1 & 16.6 \\
\hline $\mathbf{B a O}$ & 0.216 & 0.211 & 0.211 & 0.235 & 0.240 & 0.220 & 0.229 \\
\hline $\mathrm{CaO}$ & 3.39 & 3.03 & 3.05 & 3.45 & 3.47 & 3.08 & 3.35 \\
\hline $\mathrm{Cr}_{2} \mathrm{O}_{3}$ & 1.02 & $\mathrm{~N} / \mathrm{A}$ & $\mathrm{N} / \mathrm{A}$ & 0.706 & 0.716 & 0.558 & 0.580 \\
\hline $\mathrm{CuO}$ & 0.086 & 0.148 & 0.028 & 0.174 & 0.111 & 0.144 & 0.135 \\
\hline $\mathrm{Fe}_{2} \mathrm{O}_{3}$ & 34.7 & 33.8 & 33.2 & 36.7 & 36.7 & 33.8 & 34.6 \\
\hline $\mathrm{Gd}_{2} \mathrm{O}_{3}$ & 0.006 & 0.047 & 0.044 & 0.049 & 0.050 & 0.047 & 0.048 \\
\hline $\mathrm{K}_{2} \mathrm{O}$ & 0.014 & 0.055 & 0.038 & 0.106 & 0.070 & 0.047 & 0.031 \\
\hline MgO & 2.80 & 2.65 & 2.67 & 2.84 & 2.99 & 3.52 & 3.62 \\
\hline MnO & 6.20 & 5.86 & 5.92 & 6.46 & 6.17 & 6.01 & 5.90 \\
\hline $\mathrm{Na}_{2} \mathrm{O}$ & 29.8 & 30.5 & 31.1 & 24.0 & 22.2 & 26.4 & 26.9 \\
\hline $\mathrm{NiO}$ & 1.13 & 1.08 & 1.04 & 1.23 & 1.23 & 1.16 & 1.14 \\
\hline PbO & 0.008 & 0.019 & 0.009 & $<0.020$ & $<0.020$ & 0.016 & 0.012 \\
\hline $\mathrm{SiO}_{2}$ & 2.16 & 2.08 & 2.12 & 2.44 & 2.45 & 2.21 & 2.17 \\
\hline $\mathrm{TiO}_{2}$ & 0.025 & 0.043 & 0.042 & 0.026 & 0.026 & 0.031 & 0.033 \\
\hline $\mathrm{ZnO}$ & 0.356 & 0.347 & 0.342 & 0.389 & 0.403 & 0.365 & 0.375 \\
\hline $\mathrm{ZrO}_{2}$ & 0.625 & 0.591 & 0.604 & 0.681 & 0.700 & 0.628 & 0.647 \\
\hline Totals & 98.64 & 96.36 & 96.62 & 97.39 & 95.23 & 95.34 & 96.37 \\
\hline
\end{tabular}

All of the results had good oxide recovery since acceptable recovery equals a sum of oxides of $100+5 \%$. When the SRAT product compositions are compared within the target cases, most of the oxides are very similar. As with the "sludge" and "receipt" sample data, some problems exist with the minor constituents. Cr was still high, as it was in the sludge sample. Cu shows a large variation and is not consistent with the receipt data. Gd is low for SB3A-14 and significant scatter still exists for K. Overall, the compositions represented a reasonable estimation of the SB3 simulant major components.

The SRAT products from the $24 \mathrm{~K}$ case were also filtered to remove the supernate, so the soluble components could be determined. The supernate cation concentrations are given in Table 8. The density of the SB3A-19 supernate was 1.12 $\mathrm{g} / \mathrm{ml}$, while the density of the supernate from SB3A-20 was $1.10 \mathrm{~g} / \mathrm{ml}$. The sludge for the runs was also measured for comparison and is given in Table 8 . The sludge supernate density for the runs was $1.11 \mathrm{~g} / \mathrm{ml}$. Fe was completely insoluble in all samples.

Table 8: Filtered SLUDGE and SRAT Product Supernate

\begin{tabular}{|c||c||c|c|c|c|c|c|}
\hline Sample ID & Unit & Al & Ba & Ca & Cr & Cu & Mg \\
\hline \hline \multirow{2}{*}{ SB3A-19/20 Sludge } & $\mathrm{mg} / 1$ & 251 & $<0.010$ & 15.3 & 6.15 & $<0.010$ & $<0.010$ \\
\cline { 2 - 9 } & Relative $\%$ & $1.48 \%$ & $\mathrm{~N} / \mathrm{A}$ & $0.36 \%$ & $0.93 \%$ & $\mathrm{~N} / \mathrm{A}$ & $\mathrm{N} / \mathrm{A}$ \\
\hline \multirow{2}{*}{ SB3A-19 SRAT } & $\mathrm{mg} / \mathrm{l}$ & 0.307 & 0.128 & 2070 & $<0.050$ & 0.210 & 3950 \\
\cline { 2 - 9 } & Relative $\%$ & $0 \%$ & $0.03 \%$ & $48.3 \%$ & $\mathrm{~N} / \mathrm{A}$ & $0.09 \%$ & $95.6 \%$ \\
\hline \multirow{2}{*}{ SB3A-20 SRAT } & $\mathrm{mg} / \mathrm{l}$ & 6.30 & 0.488 & 2400 & 0.192 & 2.31 & 4230 \\
\cline { 2 - 9 } & Relative $\%$ & $0.04 \%$ & $0.13 \%$ & $54.6 \%$ & $0.03 \%$ & $1.16 \%$ & $100 \%$ \\
\hline \hline \multirow{2}{*}{ SB3A-19/20 Sludge } & Unit & $\mathbf{M n}$ & $\mathbf{N a}$ & $\mathbf{N i}$ & $\mathbf{S i}$ & $\mathbf{Z n}$ & $\mathbf{Z r}$ \\
\cline { 2 - 8 } & Relative $\%$ & $\mathrm{~N} / \mathrm{A}$ & $100 \%$ & $\mathrm{~N} / \mathrm{A}$ & $0.31 \%$ & $1.00 \%$ & $0.01 \%$ \\
\hline \multirow{2}{*}{ SB3A-19 SRAT } & $\mathrm{mg} / 1$ & 1470 & 44600 & 0.757 & 29.1 & $<0.010$ & 0.053 \\
\cline { 2 - 8 } & Relative $\%$ & $16.2 \%$ & $100 \%$ & $0.04 \%$ & $1.4 \%$ & $\mathrm{~N} / \mathrm{A}$ & $0.01 \%$ \\
\hline \multirow{2}{*}{ SB3A-20 SRAT } & mg/l & 8220 & 43300 & 102 & 56.0 & 16.9 & 0.044 \\
\cline { 2 - 8 } & Relative $\%$ & $97.7 \%$ & $100 \%$ & $6.15 \%$ & $3.00 \%$ & $3.04 \%$ & $0 \%$ \\
\hline
\end{tabular}

Note: Product supernate was filtered and then analyzed. Analysis was performed on one sample. The amounts detected in the supernate were ratioed to the total amount of the element available in the slurry to obtain relative $\%$ values. 
$\mathrm{Na}$ was the cation most prevalent in the sludge supernate. Al had the next highest concentration based on the absolute measurement and relative to the amount in the sludge. The cations that were most prevalent in the SRAT supernate included $\mathrm{Ca}, \mathrm{Mg}, \mathrm{Mn}$, and $\mathrm{Na}$. This is expected for $\mathrm{Na}$ since it is typically present as soluble salts, and the amount did not change much from the original sludge. The relative amounts of $\mathrm{Na}$ in the SRAT product supernate are consistent with the Phase II runs [3] and was greater than the $65 \%$ seen during the Phase I runs [2]. Ca and Mg solubility are also expected since they will form soluble compounds. Differences in the solubility of some of the minor cations (e.g., $\mathrm{Cu}$, $\mathrm{Ni}$, and $\mathrm{Zn}$ ) were also seen with the higher acid run again having higher relative concentrations. All of these species form soluble compounds with the acids used in testing. Mn is expected to be present in the SRAT product supernate based on the assumed reactions occurring during the SRAT. However, large quantities of Mn were not detected in the supernate during the Phase I runs with sodium oxalate.[2] For Phase II, Mn solubility was comparable to SB3A-19. Mn was almost completely soluble in the SB3A-20 run with higher acid. This supports reduction of $\mathrm{Mn}^{+4}$ to $\mathrm{Mn}^{+2}$, an assumed SRAT reaction.

The total and dissolved solids were measured on the SRAT products, and the insoluble and soluble solids were then calculated. As mentioned above, the calcined solids were also measured. To complete the physical property analyses, the slurry density and $\mathrm{pH}$ were measured. The results are given in Table 9.

Table 9: Physical Property Data on SRAT Products

\begin{tabular}{|c|c|c|c|c|c|c|}
\hline Sample ID & $\begin{array}{c}\text { Total } \\
\text { Solids }\end{array}$ & $\begin{array}{c}\text { Insoluble } \\
\text { Solids }\end{array}$ & $\begin{array}{c}\text { Soluble } \\
\text { Solids }\end{array}$ & $\begin{array}{c}\text { Calcined } \\
\text { Solids }\end{array}$ & $\begin{array}{c}\text { Slurry } \\
\text { Density (g/ml) }\end{array}$ & pH \\
\hline SB3A-14 & $26.1 \%$ & $11.0 \%$ & $15.1 \%$ & $14.8 \%$ & 1.24 & 4.65 \\
\hline SB3A-15 & $24.6 \%$ & $11.3 \%$ & $13.3 \%$ & $14.8 \%$ & 1.22 & 6.91 \\
\hline SB3A-16 & $26.0 \%$ & $10.0 \%$ & $16.0 \%$ & $14.9 \%$ & 1.25 & 5.09 \\
\hline SB3A-17 & $23.0 \%$ & $12.2 \%$ & $10.9 \%$ & $14.7 \%$ & 1.13 & 6.86 \\
\hline SB3A-18 & $23.8 \%$ & $11.7 \%$ & $12.1 \%$ & $14.7 \%$ & 1.13 & 6.55 \\
\hline SB3A-19 & $25.4 \%$ & $12.0 \%$ & $13.4 \%$ & $15.3 \%$ & 1.19 & 7.50 \\
\hline SB3A-20 & $25.8 \%$ & $10.5 \%$ & $15.3 \%$ & $15.0 \%$ & 1.21 & 6.09 \\
\hline
\end{tabular}

Note: Measured on two aliquots from the same sample. Data reported is an average. Total and dissolved solids were actually measured and insoluble and soluble solids were calculated. The $\mathrm{pH}$ is measured at room temperature versus the $\mathrm{pH}$ measured at boiling in Figure 2, so is expected to change slightly.

The total solids were consistently higher in the runs with higher acid, which was likely due to the additional solids added with the acid. The numbers are higher than the values seen for other SB3 simulant runs.[2,3,4] The soluble solids were consistently higher for the runs with more acid, which is anticipated. The levels were also much higher than the levels seen in earlier SB3 testing due to the increase in starting nitrite and nitrate concentrations. The reported calcined solids had a relatively small spread for the SRAT products, and were consistent with earlier runs. $[2,3,4]$ However when ratioed to the total solids, a lower calcine factor is found for these sludge simulants than for past simulants. Slight variation was seen in the measured slurry density from case to case, and the results were in line with previously reported slurry densities for the SB3 simulant runs [2,3] with slightly higher densities seen in the Case $6 \mathrm{~b}$ runs. Overall, the values are consistent with the Phase III studies that were just completed.[4] The product $\mathrm{pH}$ measurements were performed after the testing was complete and showed slight variation, but the trends were consistent with the $\mathrm{pH}$ measured during the runs. In most cases, numbers are slightly higher than what was seen at the end of the process, when the slurries were at elevated temperatures.

\subsection{SME Product Characterization}

The SME product from each run was characterized for the anion concentration, cation concentration, solids content, density, and $\mathrm{pH}$. As mentioned earlier, the SME cycle was not completed for Run SB3A-14 because the hydrogen limit had already been exceeded, and the SME could not be completed for Run SB3A-15 because of a vessel overpressurization situation. Therefore, the products from these two runs were not characterized. The product anion concentrations for the remaining runs are given in Table 10. On an absolute concentration basis, most of the SME product anions increased over the reported SRAT product anion concentrations. A few exceptions were noted, nitrate decreased slightly for SB3A-16. Both SB3A-17 and SB3A-19 were below $1000 \mathrm{mg} / \mathrm{kg}$ nitrite at the end of the SME. The oxalate concentration also decreased for SB3A-17 and SB3A-19. 
Table 10: SME Product Anion Concentration (mg/kg)

\begin{tabular}{|c|c|c|c|c|c|}
\hline Anion & SB3A-16 & SB3A-17* & SB3A-18* & SB3A-19* & SB3A-20* \\
\hline Nitrite & $<100$ & $<100$ & $<100$ & 362 & $<500$ \\
\hline Nitrate & 45,450 & 27,550 & 28,950 & 33,909 & 40,350 \\
\hline Formate & 65,900 & 53,450 & 62,850 & 62,900 & 63,500 \\
\hline Oxalate & 2700 & 1515 & 2715 & 1158 & 1840 \\
\hline
\end{tabular}

Note: Analyses performed on weighted dilution of samples. *Results represent an average of two measurements.

The results in Table 10, along with the known addition amount of formic acid and the mass balances given in Tables A6 to A - 12, were used to estimate the destruction that occurred during the SME cycles and in the entire SRAT/SME cycle ("Total Destruction"). The results are given in Table 11. The starting SME masses use the SRAT product anion masses from Table 6 and are adjusted for the SRAT samples that were removed before the start of the SME. The SME product mass is based on the measured SME product mass data and the anions in Table 10. The "Total" numbers given in Table 11 convey total destruction based on the starting "SRAT receipt" and ending "SME product" parameters (with the proper adjustments for sampling).

Table 11: Destruction of Nitrate, Formate, and Oxalate - SRAT Product Relative to SME Product and SRAT Receipt Relative to SME Product

\begin{tabular}{|c|c|c|c|c|c|}
\hline Parameter & SB3A-16 & SB3A-17 & SB3A-18 & SB3A-19 & SB3A-20 \\
\hline 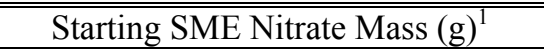 & 119.6 & 68.94 & 72.84 & 777.81 & 100.7 \\
\hline SME Product Nitrate Mass $(\mathrm{g})$ & 111.4 & 63.79 & 68.11 & 76.72 & 97.56 \\
\hline \% Nitrate Destruction in $\mathrm{SME}^{2}$ & 6.79 & 7.47 & 6.49 & 1.40 & 3.13 \\
\hline Total Nitrite to Nitrate Conversion ${ }^{3}$ & 40.9 & 30.2 & 37.5 & 27.8 & 37.0 \\
\hline$\%$ Total Nitrate Creation ${ }^{4}$ & 54.9 & 61.3 & 74.3 & 48.9 & 50.6 \\
\hline${\text { Starting SME Formate Mass }(\mathrm{g})^{1}}^{1}$ & 167.9 & 128.6 & 151.0 & 138.8 & 155.5 \\
\hline Additional Formate Added (g) & 7.274 & 7.195 & 7.195 & 7.393 & 7.393 \\
\hline SME Product Formate Mass (g) & 161.6 & 123.8 & 147.9 & 142.3 & 153.5 \\
\hline \% Formate Destruction in $\mathrm{SME}^{2}$ & 7.75 & 8.89 & 6.55 & 2.67 & 5.79 \\
\hline \% Total Formate Destruction ${ }^{4}$ & 28.9 & 22.7 & 21.7 & 23.3 & 27.1 \\
\hline Starting SME Mass $(\mathrm{g})^{1}$ & 6.868 & 5.251 & 6.199 & 3.604 & 4.528 \\
\hline SME Product Oxalate Mass (g) & 6.620 & 3.508 & 6.387 & 2.620 & 4.449 \\
\hline$\%$ Oxalate Destruction in SME ${ }^{2}$ & 3.61 & 33.2 & -3.03 & 27.3 & 1.75 \\
\hline$\%$ Total Oxalate Destruction ${ }^{4}$ & 22.8 & 49.3 & 14.3 & 70.8 & 44.5 \\
\hline
\end{tabular}

${ }^{1}$ Starting masses reflect the estimated SRAT product masses minus the SRAT product samples removed.

${ }^{2}$ Represents difference of [(Starting mass + added) - SME product] and the percent is calculated relative to (Starting mass + added). When the value was negative, it was assumed to be created.

${ }^{3}$ Represents moles of nitrate created relative to moles of nitrite destroyed.

${ }^{4}$ Represents difference of [(SRAT receipt + added - removed in samples) - SME product] and the percent is calculated relative to [(SRAT receipt + added - removed in samples). When the value was negative, it was assumed to be created.

Unlike the SRAT, very small amounts of nitrate were destroyed during the SME; however, since all tests showed $<10 \%$ destruction, the difference could have been analytical error. When the total nitrate destruction numbers are considered, significant nitrate was created in all of the SRAT/SME cycles with nitrite conversion providing a significant contribution. A small additional amount of formate was destroyed in the SME. Total destruction was highest in SB3A16 with all having destruction in the 21 to $29 \%$ range. Earlier SB3 simulant runs with high levels of noble metals had total destruction on the order of $\sim 45 \%$ or greater.[3,5] The formate destruction seen in this set of runs is similar to that seen during the qualification of sludge batch 2.[6] Oxalate destruction once again varied greatly from run to run and within the cases. As with the SRAT testing, higher oxalate destruction may have been associated with the lower acid runs. Due to the uncertainty with the small number, it is difficult to compare oxalate destruction to previous runs with SB3 simulant.

As mentioned in section 3.2 and as shown in Table 2, nitrite to nitrate conversion and oxalate and formate destruction values had to be assumed prior to calculating the acid split for redox balance. Total formate destruction was assumed to be 10 to $29 \%$ depending on the run. Total destruction was not calculated for runs SB3A-14 and SB3A-15 due to SME problems. For the remaining runs, the following statements summarize how well the assumptions were met: 
- For Run SB3A-16, formate destruction was much higher than assumed. Nitrite to nitrate conversion was close to the assumption.

- For Run SB3A-17, actual formate destruction was close to the assumption and was about 25\% low for Run SB3A-18 compared to the assumption. Actual nitrite to nitrate conversion was $\sim 20 \%$ less than assumed.

- For Run SB3A-19, actual formate destruction was close to the assumption and nitrite to nitrate conversion was $\sim 22 \%$ less than assumed. In Run SB3A-20, formate destruction was about $30 \%$ high compared to the assumption and nitrite to nitrate conversion was $\sim 8 \%$ less than assumed.

These changes in destruction would impact the redox target. The revised destruction/conversion numbers and the actual sample and dewater masses used during testing were incorporated into the original acid calculations to determine the impact on redox and acid stoichiometry. In addition, the input parameters were updated based on the receipt sample results given in Table A - 5. Analytical error in any of the measurements shown in Table 12 may have an impact on the percent acid stoichiometry target. In general, the actual moles of acid added per liter of slurry in the kettle were used to dictate the predicted acid stoichiometry. In other words, the moles of acid/liter are actual values, whereas the predicted acid stoichiometry is strongly dependent on the input parameters. Therefore, in the discussions on the limits of acid added, the moles of acid per liter of slurry is more meaningful. As evidenced by the range of redox projection data, the under or over predictions of destruction and conversion can cause large changes in the redox target.

Table 12: Post-Run Measured Inputs and Assumptions for Acid Calculation

\begin{tabular}{|c|c|c|c|c|c|c|c|}
\hline \multirow{2}{*}{ Input Parameter } & \multicolumn{3}{|c|}{ Case 6b } & \multicolumn{2}{c|}{ 20K Nitrite Case } & \multicolumn{2}{c|}{ 24K Nitrite Case } \\
\cline { 2 - 7 } & $\begin{array}{c}\text { SB3A- } \\
\mathbf{1 4}\end{array}$ & $\begin{array}{c}\text { SB3A- } \\
\mathbf{1 5}\end{array}$ & $\begin{array}{c}\text { SB3A- } \\
\mathbf{1 6}\end{array}$ & $\begin{array}{c}\text { SB3A- } \\
\mathbf{1 7}\end{array}$ & $\begin{array}{c}\text { SB3A- } \\
\mathbf{1 8}\end{array}$ & SB3A-19 & SB3A-20 \\
\hline Nitrite (mg/kg) & 26,600 & 25,600 & 26,000 & 21,100 & 20,400 & 24,300 & 23,500 \\
\hline Nitrate (mg/kg) & 20,300 & 19,700 & 19500 & 15,800 & 15,900 & 21,200 & 21,100 \\
\hline Oxalate (mg/kg) & 2100 & 3770 & 3300 & 2610 & 2830 & 3380 & 2990 \\
\hline TIC (mg/kg) & 840 & 1100 & 1100 & 790 & 790 & 925 & 733 \\
\hline Hydroxide - Base Equivalents (M) & 0.617 & 0.631 & 0.639 & 0.438 & 0.443 & 0.586 & 0.581 \\
\hline Mn (wt\% in dried solids) & 3.15 & 3.12 & 3.15 & 3.53 & 3.49 & 3.27 & 3.24 \\
\hline Total Solids (wt\%) & 21.3 & 21.4 & 21.3 & 21.0 & 20.8 & 21.8 & 21.5 \\
\hline Sludge Density (g/ml) & 1.20 & 1.21 & 1.21 & 1.17 & 1.17 & 1.20 & 1.21 \\
\hline Formate destruction* & $27.3 \%$ & $23.9 \%$ & $29 \%$ & $23 \%$ & $22 \%$ & $23 \%$ & $27 \%$ \\
\hline Oxalate destruction* & $5 \%$ & $5 \%$ & $29 \%$ & $49 \%$ & $14 \%$ & $70 \%$ & $44 \%$ \\
\hline Nitrite to Nitrate Conversion* & $47 \%$ & $36 \%$ & $41 \%$ & $30 \%$ & $37 \%$ & $49 \%$ & $44 \%$ \\
\hline Receipt Mass (g) & 2626.5 & 2752.9 & 2753.1 & 2819.4 & 2817.7 & 2800.1 & 2800.0 \\
\hline Predicted Acid Stoichiometry & $174.5 \%$ & $124.9 \%$ & $158.2 \%$ & $126.3 \%$ & $152.4 \%$ & $127.9 \%$ & $155.5 \%$ \\
\hline Redox Projection & 0.078 & 0.159 & 0.079 & 0.171 & 0.239 & 0.070 & 0.093 \\
\hline Moles of Acid/Liter of Slurry & 2.584 & 1.922 & 2.460 & 1.500 & 1.790 & 1.837 & 2.154 \\
\hline Moles of Formic/Liter of Slurry & 2.408 & 1.878 & 2.274 & N/A & N/A & N/A & 2.064 \\
\hline
\end{tabular}

*Since the SME was not completed, assumed reactions for the SME were performed for runs SB3A-14 and SB3A-15 based on the existing SRAT data and the other SME data.

Since excess formic acid is known to cause hydrogen generation problems, the differences in the moles of formic acid per liter of slurry for each case were evaluated to determine if any trends were obvious. Each case had a run that roughly approximated a minimum acid level required for nitrite destruction and the higher acid run would be considered to have excess acid. For the Case $6 \mathrm{~b}$ runs, the difference was 0.396 moles of formic acid/liter of slurry (SB3A-15 versus SB3A-16), and this amount created too much hydrogen during the SME cycle. For the 20K case, the difference was 0.29 moles of formic acid/liter of slurry (SB3A-17 versus SB3A-18), and the amounts of hydrogen generated in both the SRAT and SME were acceptable. Finally for the $24 \mathrm{~K}$ case, the difference was 0.227 moles of formic acid/liter of slurry, and no hydrogen generation problems were observed in the SRAT or the SME. For this particular sludge batch system and with the level of noble metals approximated by the target cases, the data suggest that if excess acid is not exceeded beyond 0.29 moles of formic acid/liter of slurry, then hydrogen generation should not be a concern. The data from the Phase III runs was also considered in this evaluation. For Case 6 from the Phase III runs, the difference in formic acid levels was 0.393 moles/liter of slurry (SB3A-10 versus SB3A-11).[4] This resulted in excessive hydrogen generation in the SRAT. For Case 7 from the Phase III runs, the difference in formic acid levels was 0.231 moles/liter of slurry (SB3A-12 versus SB3A-13), and excessive hydrogen generation was not seen.[4] This run, SB3A-13, reached 
$\sim 50 \%$ of the SME hydrogen limit. However all four of these runs were performed with much higher levels of noble metals than the current phase of testing, so less acid would be required to generate excessive hydrogen. This trend will continue to be monitored and investigated in other data to determine if it has any validity.

As mentioned in Section 4.0, the SME products were calcined at $1100^{\circ} \mathrm{C}$ in order to prepare them for cation analyses. The oxides detected in the calcined solids are given as Table 13. A calculation to determine the actual waste loading was performed for each of the SME products based on the $\mathrm{Li}_{2} \mathrm{O}$ content in the SME product and the analyzed Frit 202 composition (i.e., $6.76 \mathrm{wt} \% \mathrm{Li}_{2} \mathrm{O}$ ). The average of the two calculated waste loadings is reported.

Table 13: SME Product Results (Calcined Solids Wt\%)

\begin{tabular}{|c|c|c|c|c|c|}
\hline \multirow{2}{*}{ Oxide } & \multirow{2}{*}{$\begin{array}{c}\text { Case 6b } \\
\text { SB3A-16 }\end{array}$} & \multicolumn{2}{|c|}{ 20K Nitrite Case } & \multicolumn{2}{|c|}{ 24K Nitrite Case } \\
\hline & & SB3A-17 & SB3A-18 & SB3A-19 & SB3A-20 \\
\hline$\overline{\mathrm{Al}_{2} \mathbf{O}_{3}}$ & 6.65 & 7.19 & 7.21 & 6.62 & 6.66 \\
\hline $\mathrm{B}_{2} \mathbf{O}_{3}$ & 4.31 & 4.80 & 4.88 & 4.81 & 4.83 \\
\hline BaO & 0.078 & 0.086 & 0.085 & 0.083 & 0.083 \\
\hline $\mathrm{CaO}$ & 1.28 & 1.50 & 1.48 & 1.31 & 1.32 \\
\hline $\mathrm{Cr}_{2} \mathrm{O}_{3}$ & N/A & 0.264 & 0.263 & 0.215 & 0.214 \\
\hline $\mathrm{CuO}$ & 0.044 & 0.072 & 0.066 & 0.068 & 0.064 \\
\hline $\mathrm{Fe}_{2} \mathrm{O}_{3}$ & 12.6 & 14.3 & 14.1 & 12.5 & 13.0 \\
\hline $\mathbf{G d}_{2} \mathrm{O}_{3}$ & 0.017 & 0.017 & 0.017 & 0.017 & 0.017 \\
\hline $\mathrm{K}_{2} \mathrm{O}$ & 0.122 & 0.146 & 0.148 & 0.112 & 0.109 \\
\hline $\mathbf{L i}_{2} \mathbf{O}$ & 4.10 & 4.13 & 4.19 & 4.21 & 4.22 \\
\hline MgO & 2.31 & 2.34 & 2.33 & 2.61 & 2.57 \\
\hline MnO & 2.13 & 2.47 & 2.46 & 2.15 & 2.18 \\
\hline $\mathrm{Na}_{2} \mathrm{O}$ & 16.5 & 13.8 & 13.8 & 14.4 & 14.9 \\
\hline $\mathrm{NiO}$ & 0.406 & 0.418 & 0.427 & 0.410 & 0.437 \\
\hline PbO & 0.095 & 0.096 & 0.094 & 0.048 & 0.045 \\
\hline $\mathrm{SiO}_{2}$ & 48.8 & 48.7 & 49.4 & 49.0 & 49.0 \\
\hline $\mathrm{TiO}_{2}$ & 0.043 & N/A & N/A & 0.033 & 0.033 \\
\hline $\mathrm{ZnO}$ & 0.128 & 0.144 & 0.140 & 0.126 & 0.129 \\
\hline $\mathrm{ZrO}_{2}$ & 0.261 & 0.265 & 0.262 & 0.250 & 0.247 \\
\hline Totals & 99.87 & 100.74 & 101.40 & 98.97 & 100.06 \\
\hline $\begin{array}{l}\text { Calculated } \\
\text { Waste } \\
\text { Loading }\end{array}$ & $39.2 \%$ & $39.5 \%$ & $39.0 \%$ & $37.3 \%$ & $37.7 \%$ \\
\hline
\end{tabular}

Note: Two aliquots removed from product sample then calcined and analyzed. Results represent an average of the two measurements. Waste loading is calculated using the $\mathrm{Li}_{2} \mathrm{O}$ detected in the $\mathrm{SME}$ product relative to the $\mathrm{Li}_{2} \mathrm{O}$ detected in the frit. It was performed on each ICP result and the result represents the average value.

All total oxide sums for the SME product were within $100 \pm 5 \%$, indicating good recovery from the digestion and analyses. Within the particular endpoint cases, the compositions were fairly consistent and no obvious outliers are seen. Based on the SME composition results for $\mathrm{Li}_{2} \mathrm{O}$ and the analyzed Frit 202 composition (i.e., 6.76 wt $\% \mathrm{Li}_{2} \mathrm{O}$ ), the calculated waste loadings met the target of $38 \mathrm{wt} \%$ waste loading fairly well.

The SME products from the $24 \mathrm{~K}$ case were also filtered to remove the supernate, so the soluble components could be determined. The supernate cation concentrations are given Table 14. The density of the supernate was also measured and was $1.18 \mathrm{~g} / \mathrm{ml}$ for both SME product samples. Iron was, once again, completely insoluble in the product sample. 
Table 14: Filtered SME Product Supernate (mg/L)

\begin{tabular}{|c|c||c|c|c|c|c|c|c|}
\hline Sample ID & Unit & Al & B & Ba & Ca & Cr & Cu & Li \\
\hline \hline \multirow{2}{*}{ SB3A-19 } & $\mathrm{mg} / 1$ & 0.355 & 137 & 0.194 & 3270 & $<0.050$ & 0.144 & 612 \\
\cline { 2 - 9 } & Relative \% & 0 & 1.10 & 0.03 & 41.9 & N/A & 0.03 & 3.73 \\
\hline \multirow{2}{*}{ SB3A-20 } & $\mathrm{mg} / \mathrm{l}$ & 0.930 & 197 & 0.290 & 2650 & 0.111 & 1.35 & 452 \\
\cline { 2 - 9 } & Relative $\%$ & 0 & 1.73 & 0.05 & 37.0 & 0.01 & 0.35 & 3.03 \\
\hline \multirow{2}{*}{ Sample ID } & Unit & Mg & Mn & Na & Ni & Si & Zn & Zr \\
\hline \hline \multirow{2}{*}{ SB3A-19 } & $\mathrm{mg} / 1$ & 6170 & 2760 & 72100 & 1.32 & 48.6 & $<0.010$ & 0.047 \\
\cline { 2 - 9 } & Relative \% & 47.0 & 19.8 & 81.0 & 0.05 & 0.03 & N/A & 0 \\
\hline \multirow{2}{*}{ SB3A-20 } & mg/l & 5380 & 5520 & 66800 & 14.4 & 71.8 & 1.19 & 0.048 \\
\cline { 2 - 8 } & Relative \% & 45.8 & 43.1 & 79.7 & 0.55 & 0.04 & 0.15 & 0 \\
\hline
\end{tabular}

Note: Product supernate was filtered and then analyzed. Analysis was performed on one sample. The amounts detected In the supernate were ratioed to the total amount of the element available in the slurry to obtain relative $\%$ values.

Generally speaking, the SME product supernate had fewer soluble metals/cations present, especially for the components that were also present in the frit. $\mathrm{Mg}$ and $\mathrm{Na}$ are a good example of this change since they are both frit components. For SB3A-19, Ca solubility was approximately the same as in the SRAT product sample, but it decreased for SB3A-20. Mn exhibited similar behavior, possibly indicating that some of the reduction that occurred in the SRAT was reversed in the SME due to the formic frit slurry addition. Some of the minor components, i.e., $\mathrm{Cu}, \mathrm{Ni}$, and $\mathrm{Zn}$, also exhibited this same behavior. In general, the predominately frit components $(\mathrm{B}, \mathrm{Li}$, and $\mathrm{Si}$ ) showed very limited solubility. The principle sludge components, $\mathrm{Al}$ and $\mathrm{Fe}$, were completely insoluble. The changes shown here indicate that significant reactions were still occurring in the SME. This was supported to an extent by the additional gases generated in the SME.

The total and dissolved solids were measured on the SME products, and the insoluble and soluble solids were then calculated. As mentioned above, the calcined solids were also measured. To complete the physical property analyses, the slurry density and final $\mathrm{pH}$ were measured. The results are given in Table 15.

Table 15: Physical Property Data on SME Products

\begin{tabular}{|c|c|c|c|c|c|c|}
\hline Sample ID & $\begin{array}{c}\text { Total } \\
\text { Solids }\end{array}$ & $\begin{array}{c}\text { Insoluble } \\
\text { Solids }\end{array}$ & $\begin{array}{c}\text { Soluble } \\
\text { Solids }\end{array}$ & $\begin{array}{c}\text { Calcined } \\
\text { Solids }\end{array}$ & $\begin{array}{c}\text { Slurry } \\
\text { Density } \\
(\mathbf{g} / \mathbf{m l})\end{array}$ & $\mathbf{p H}$ \\
\hline SB3A-16 & $50.3 \%$ & $35.9 \%$ & $14.4 \%$ & $39.3 \%$ & 1.43 & 5.59 \\
\hline SB3A-17 & $49.0 \%$ & $36.4 \%$ & $12.6 \%$ & $41.3 \%$ & 1.49 & 7.33 \\
\hline SB3A-18 & $50.7 \%$ & $37.3 \%$ & $13.4 \%$ & $41.5 \%$ & 1.55 & 6.51 \\
\hline SB3A-19 & $53.8 \%$ & $38.7 \%$ & $15.1 \%$ & $43.5 \%$ & 1.54 & 7.61 \\
\hline SB3A-20 & $51.8 \%$ & $36.3 \%$ & $15.5 \%$ & $40.9 \%$ & 1.54 & 6.98 \\
\hline
\end{tabular}

Note: Measured on two aliquots from the same sample. Data reported is an average. Total and dissolved solids were actually measured and insoluble and soluble solids were calculated. The $\mathrm{pH}$ is measured at room temperature versus the $\mathrm{pH}$ measured at boiling in Figure 3, so is expected to change slightly.

The SME target solids was 50\%. For Runs SB3A-16 through SB3A-18, the actual SME solids were close to target. Run SB3A-19 was boiled for an extended period and additional samples were removed during the SRAT processing, but the target frit addition was not revised. When the original acid addition and frit calculations were made, both of the $24 \mathrm{~K}$ case runs had an erroneous sludge density, and this may have also impacted the $\mathrm{wt} \%$ solids. The insoluble and soluble solids were different for each case. In general, the higher acid runs in the case pairs had higher soluble solids, which is consistent with theory and with the behavior exhibited in the SRAT. The calcined solids target was $\sim 40 \%$ based on the typical calcine factor of 0.8. The products were close to the target. Run SB3A-19 had higher calcined solids than the rest of the runs, but it also had a higher total solids so this would be anticipated. Slight variation was seen in the measured slurry density from run to run, and the results were in line with previously reported slurry densities for the SB3 simulant runs.[3,4] The product $\mathrm{pH}$ measurements showed slight variation, but were slightly higher than the $\mathrm{pH}$ values measured during the runs. These numbers are slightly higher than what was seen at the end of the process, when the slurries were at elevated temperatures. 


\subsection{CONCLUSIONS AND PATH FORWARD}

The SRAT/SME runs with SB3 simulant at the various target endpoint cases and the estimated noble metals levels were completed to define an endpoint for the Shielded Cells run. The data will also be used to support the plant washing strategy for SB3. The SB3 compositions tested included Case $6 \mathrm{~b}(\sim 26,000 \mathrm{mg}$ nitrite/kg sludge slurry), $20 \mathrm{~K}$ case ( $\sim 20,000 \mathrm{mg}$ nitrite/kg sludge slurry), and the $24 \mathrm{~K}$ case $(\sim 24,000 \mathrm{mg}$ nitrite/kg sludge slurry). While not every run was considered a complete success from a nitrite destruction and hydrogen generation perspective, the combined data set provides estimates of the acid addition windows for each case. Information on the expected formate destruction and nitrite to nitrate conversion for each case was also gained. The data indicate that an upper limit on the acid addition amount would have to be implemented in the DWPF if SB3 were to be processed without blending with sludge batch 2 and if the noble metals behavior was the same in the actual sludge. This limit would best be placed on the amount of formic acid since its addition primarily drives the hydrogen generation, and this could be assisted by adjusting the redox target to $<0.200 \mathrm{Fe}^{2+} / \sum \mathrm{Fe}$. This limit may also be necessary for the combined sludge batch. No significant processing problems such as foaming, loss of heat transfer, or air entrainment were seen with this simulant. Mercury reduction was not characterized in these runs because the anticipated Hg content was already below the DWPF limit.

The data from the seven runs indicated that the $24 \mathrm{~K}$ case should provide a feasible window for acid addition in the qualification of SB3. This nitrite endpoint also assists the plant in minimizing the amount of waste generated from washing since no washing would be required at this endpoint. Once the data from the characterization of the SB3 Tank 51 qualification sample after adjusting with $\mathrm{Pu}$ and $\mathrm{Np}$ is available, the composition will be evaluated and a recommendation for the Shielded Cells chemical process cell qualification will then be made.

Since it is anticipated that SB3 will be combined with SB2 to be processed in DWPF, additional runs will be performed as necessary to identify processing parameters for the blend of SB3 with SB2. This will be done to help understand processing issues that may arise with the actual sludge batch in DWPF. Bounding levels of acid will also be defined as necessary for this scenario so that processing upsets can be anticipated and solutions implemented.

\subsection{REFERENCES}

[1] M.A. Rios-Armstrong, Sludge Batch 3 Flowsheet Studies, HLW/DWPF/TTR-02-0016, October 30, 2002, Westinghouse Savannah River Company, Aiken, South Carolina.

[2] C.C. Herman, D.C. Koopman, D.R. Best, and M.F. Williams, "Sludge Batch 3 Simulant Flowsheet Studies: Phase I SRAT Results", WSRC-TR-2003-00088, March 20, 2003, Westinghouse Savannah River Company, Aiken, South Carolina.

[3] C.C. Herman, D.C. Koopman, D.R. Best, and M.F. Williams, "Sludge Batch 3 Simulant Flowsheet Studies: Phase II SRAT/SME Results", WSRC-TR-2003-00158, April 25, 2003, Westinghouse Savannah River Company, Aiken, South Carolina.

[4] D.C. Koopman, C.C. Herman, D.R. Best, and M.F. Williams, "Sludge Batch 3 Simulant Flowsheet Studies: Preliminary Phase III SRAT/SME Results", WSRC-TR-2003-00283, September 9, 2003, Westinghouse Savannah River Company, Aiken, South Carolina.

[5] C.C. Herman, D.R. Best, D.C. Koopman, and M.F. Williams, "Data Summary from SRAT Runs SB3-19 to SB3-24 to Evaluate Sodium Oxalate Addition Levels and SME Processing", SRT-GPD-2002-00200, January 27, 2003, Westinghouse Savannah River Company, Aiken, South Carolina.

[6] T.L. Fellinger, J.M. Pareizs, N.E. Bibler, A.D. Cozzi, and C.L. Crawford, "Confirmation Run of the DWPF SRAT Cycle Using the Sludge-Only Flowsheet with Tank 40 Radioactive Sludge and Frit 200 in the Shielded Cells Facility", WSRC-TR-2002-0076, April 30, 2002, Westinghouse Savannah River Company, Aiken, South Carolina. 
[7] C.C. Herman, "Task Technical \& QA Plan: Sludge Batch 3 Simulant Flowsheet Studies", WSRC-RP-200200563, November 8, 2002, Westinghouse Savannah River Company, Aiken, South Carolina.

[8] D.C. Koopman, C.M. Jantzen, and T.B. Edwards, "Acid Addition Stoichiometry for Sludge Batch 3 Processing in the Defense Waste Processing Facility", WSRC-TR-2003-00118, February 27, 2003, Westinghouse Savannah River Company, Aiken, South Carolina.

[9] C.M. Jantzen, J.R. Zamecnik, D.C. Koopman, C.C. Herman, and J.B. Pickett, "Electron Equivalents Model for Controlling Reduction-Oxidation (Redox) Equilibrium during High Level Waste (HLW) Vitrification", WSRC-TR-2003-00126, Westinghouse Savannah River Company, Aiken, South Carolina.

[10] N.E. Bibler and D.R. Click, "Oxalate Concentration in the Third Sample of Mixed Tank Seven Slurry Using an Acid Dissolution Technique", SRT-ITB-2003-0011, March 10, 2003, Westinghouse Savannah River Company, Aiken, South Carolina.

[11] D.R. Click and C.J. Coleman, "Measured Coal Concentration in the First, Second, and Third Samples of Mixed Tank Seven Slurry Using Loss on Ignition (LOI) and Thermal Gravimetric Analysis (TGA)", SRTADS-2003-0005, June 9, 2003, Westinghouse Savannah River Company, Aiken, South Carolina.

[12] N.E. Bibler, "Noble Metal Concentrations in the First, Second, and Third Samples of Mixed Tank 7 Slurry", SRT-ITB-2003-00033, April 30, 2003, Westinghouse Savannah River Company, Aiken, South Carolina.

[13] G.R. Lilliston, J.M. Gillam, and M.A. Rios-Armstrong, "Washing and Addition Strategies for the Combination of Pu, Np, and Sludge Batch 2 with Sludge Batch 3 as Feed into DWPF", CBU-PED-200300017, June 16, 2003, Westinghouse Savannah River Company, Aiken, South Carolina.

[14] D.K. Peeler, N.E. Bibler, and T.B. Edwards, "An Assessment of the Impacts of Adding Am/Cm and Pu/Gd Waste Streams to Sludge Batch 3 (SB3) on DWPF $\mathrm{H}_{2}$ Generation Rates and Glass Properties", WSRC-TR2002-00145, March 22, 2002, Westinghouse Savannah River Company, Aiken, South Carolina.

[15] M.A. Baich, C.C. Herman, D.C. Koopman, D.R. Best, and M.F. Williams, "Processing Options and Impact of Incorporation of ARP in the DWPF Process Flow Sheet", WSRC-TR-2003-00326, August 14, 2003, Westinghouse Savannah River Company, Aiken, South Carolina.

[16] N.E. Bibler, "Major Elemental Compositions of the First Three Tank 7 Samples", SRT-ITB-2003-00017, March 19, 2003, Westinghouse Savannah River Company, Aiken, South Carolina.

[17] D.R. Click, "Elemental Composition of Initial Tank Fifty One Sample Including Noble Metals", SRT-ADS2003-0390, July 21, 2003, Westinghouse Savannah River Company, Aiken, South Carolina.

[18] D.R. Click, "Measured Coal Concentration in the Initial Tank Fifty One Sample by Thermogravimetric Analysis (TGA)", SRT-ADS-2003-0392, July 22, 2003, Westinghouse Savannah River Company, Aiken, South Carolina.

[19] L27 Manual, ITS/TNX Procedures Manual, 2002.

[20] C.C. Herman, “Analytical Study Plan: Sludge Batch 3 Simulant Flowsheet Studies”, WSRC-RP-2002-00577, November 12, 2002, Westinghouse Savannah River Company, Aiken, South Carolina. 


\subsection{ACKNOWLEDGMENTS}

The authors would like to acknowledge the following personnel and groups for their assistance in performing the studies and analyzing the required samples:

- T.O. Burckhalter, J.W. Duvall, S.O. King, I.A. Reamer, V.J. Williams, and R.J. Workman, for performing the SRAT runs.

- P.A. Toole, J. Jansen, and J.G. Wheeler for providing assistance with the analyses.

- A.A. Ekechukwu, J.E. Young, and ADS for providing analytical support. 
Table A - 1: SB3 Simulant Sludge Composition and Chemicals Used to Adjust the Sludge to Match the Target Endpoints

\begin{tabular}{|c|c|c|c|c|c|c|}
\hline Element & $\begin{array}{c}\text { SB3 Simulant } \\
\text { Composition* } \\
\text { (Wt\% Total } \\
\text { Solids) }\end{array}$ & $\begin{array}{c}\text { Material to be } \\
\text { Added }\end{array}$ & $\begin{array}{l}\text { SB3A-14 } \\
\text { (g) }\end{array}$ & $\begin{array}{c}\text { SB3A-15/16 } \\
\text { (g) }\end{array}$ & $\begin{array}{c}\text { SB3A-17/18 } \\
\text { (g) }\end{array}$ & $\begin{array}{c}\text { SB3A-19/20 } \\
\text { (g) }\end{array}$ \\
\hline $\mathrm{Al}$ & 10.3 & SB3 Simulant & 1970.7 & 4077.2 & 4715.2 & 4368 \\
\hline $\mathrm{Ba}$ & 0.234 & $\mathrm{Cr}_{2} \mathrm{O}_{3}$ & 4.026 & 8.331 & 6.592 & 4.7732 \\
\hline $\mathrm{Ca}$ & 2.77 & $\mathrm{Gd}\left(\mathrm{NO}_{3}\right)_{3} * 6 \mathrm{H}_{2} \mathrm{O}$ & 0.429 & 0.891 & 1.026 & 0.9490 \\
\hline $\mathrm{Cr}$ & 0.053 & $\mathrm{KNO}_{3}$ & 0.926 & 1.917 & 2.2160 & $\mathrm{~N} / \mathrm{A}$ \\
\hline $\mathrm{Cu}$ & 0.176 & $\mathrm{Mg}(\mathrm{OH})_{2}$ & 15.588 & 32.252 & 37.298 & 44.7733 \\
\hline $\mathrm{Fe}$ & 28.4 & $\mathrm{Na}_{3} \mathrm{PO}_{4}$ & 0.677 & 1.401 & 0.1739 & 0.3747 \\
\hline $\mathrm{Gd}$ & 0.007 & $\mathrm{Na}_{2} \mathrm{CO}_{3}$ & 14.217 & 29.417 & 7.7386 & 11.3785 \\
\hline $\mathrm{K}$ & 0.167 & $\mathrm{NaF}$ & 1.920 & 3.974 & 2.3045 & 6.0572 \\
\hline $\mathrm{Mg}$ & 0.209 & $\mathrm{NaCl}$ & 13.672 & 28.287 & 32.379 & 30.3051 \\
\hline $\mathrm{Mn}$ & 5.65 & $\mathrm{NaOH}$ & 46.836 & 96.906 & 75.26 & 96.3158 \\
\hline $\mathrm{Na}$ & 1.05 & $\mathrm{NaNO}_{3}$ & 76.456 & 158.188 & 126.128 & 177.9657 \\
\hline $\mathrm{Ni}$ & 1.08 & $\mathrm{NaNO}_{2}$ & 114.468 & 236.831 & 188.827 & 226.6125 \\
\hline $\mathrm{Pb}$ & 0.006 & $\mathrm{Na}_{2} \mathrm{SO}_{4}$ & 5.866 & 12.137 & 5.734 & 12.8623 \\
\hline $\mathrm{Si}$ & 1.15 & $\mathrm{PbSO}_{4}$ & 1.341 & 2.775 & 3.209 & 1.3649 \\
\hline $\mathrm{Zn}$ & 0.339 & Dilution Water & $\mathrm{N} / \mathrm{A}$ & 975.2 & 712.3 & 932.4 \\
\hline $\mathrm{Zr}$ & 0.567 & & & & & \\
\hline
\end{tabular}

*Simulant composition represents an average of analyses performed on duplicate samples by the SRTC-Mobile Lab in June 2003. 
Table A - 2: SRAT/SME Run Parameters

\begin{tabular}{|c|c|c|c|c|c|c|c|}
\hline Parameter & SB3A-14 & SB3A-15 & SB3A-16 & SB3A-17 & SB3A-18 & SB3A-19 & SB3A-20 \\
\hline Target Endpoint & Case $6 \mathrm{~b}$ & Case $6 \mathrm{~b}$ & Case $6 \mathrm{~b}$ & 20 K Nitrite & $20 \mathrm{~K}$ Nitrite & 24K Nitrite & 24K Nitrite \\
\hline Sand Content (grams added) & 4.446 & 4.8177 & 4.8173 & 2.259 & 2.259 & 3.304 & 3.304 \\
\hline Coal Content (grams added) & 1.482 & 1.605 & 1.6052 & 0.321 & 0.321 & 0.326 & 0.326 \\
\hline HgO Content (grams added) & 2.27 & 2.4607 & 2.4608 & 2.054 & 2.054 & 2.141 & 2.141 \\
\hline $\mathrm{AgNO}_{3}$ Content (grams added) & 0.158 & 0.1714 & 0.172 & 0.119 & 0.119 & 0.11 & 0.11 \\
\hline $\mathrm{Pd}\left(\mathrm{NO}_{3}\right)_{2} * \mathrm{H}_{2} \mathrm{O}$ Content (grams added) & 0.1495 & 0.1619 & 0.1624 & 0.0856 & 0.0856 & 0.077 & 0.077 \\
\hline $\mathrm{Rh}\left(\mathrm{NO}_{3}\right)_{3} * 2 \mathrm{H}_{2} \mathrm{O}$ Content (grams added) & 1.447 & 1.568 & 1.5679 & 0.8921 & 0.8921 & 0.831 & 0.83 \\
\hline $\mathrm{RuCl}_{3}$ Content (grams added) & 0.7769 & 0.8426 & 0.8426 & 0.538 & 0.538 & 0.501 & 0.501 \\
\hline Rinse Water for Trim Chemicals (g) & 142.3 & 150.03 & 150.06 & 150.0 & 150.0 & 150.0 & 150.0 \\
\hline Sludge Slurry Mass at Endpoint (g) & 2573.5 & 2738.4 & 2738.4 & 2793.7 & 2793.7 & 2792.7 & 2792.7 \\
\hline Starting SRAT Feed Amount after Receipt Sampling (g) & 2626.53 & 2752.88 & 2753.13 & 2819.94 & 2817.66 & 2800.06 & 2799.99 \\
\hline DWPF SRAT Scale Factor $(6,000$ gallon basis $)$ & 10377 & 9983 & 9982 & 9423 & 9431 & 9734 & 9734 \\
\hline Nitric Acid Amount Added (ml) & 37.52 & 9.81 & 41.27 & $\mathrm{~N} / \mathrm{A}$ & $\mathrm{N} / \mathrm{A}$ & $\mathrm{N} / \mathrm{A}$ & 20.05 \\
\hline Nitric Acid Addition Rate (ml/min) & 0.77 & 0.82 & 0.82 & $\mathrm{~N} / \mathrm{A}$ & $\mathrm{N} / \mathrm{A}$ & $\mathrm{N} / \mathrm{A}$ & 0.82 \\
\hline Nitric Acid Moles & 0.385 & 0.101 & 0.423 & $\mathrm{~N} / \mathrm{A}$ & N/A & $\mathrm{N} / \mathrm{A}$ & 0.209 \\
\hline Formic Acid Amount Added (ml) & 227.02 & 187.76 & 227.41 & 154.34 & 184.03 & $172.66 / 6.9 / 4.55$ & 205.11 \\
\hline Formic Acid Addition Rate (ml/min) & 0.77 & 0.84 & 0.84 & 0.83 & 0.83 & 0.84 & 0.84 \\
\hline Formic Acid Moles & 5.271 & 4.272 & 5.174 & 3.615 & 4.310 & $4.02 / 0.161 / 0.106$ & 4.775 \\
\hline SRAT Dewater Amount (g) & 333.49 & 208.0 & 277.09 & 191.2 & 217.1 & 200.51 & 282.39 \\
\hline Condensing/Dewater Time during SRAT (hrs) & 0.95 & 1.15 & 1.38 & 1.03 & 0.97 & 1.08 & 0.90 \\
\hline Total SRAT Time in Reflux (hrs) & 12 & 12.13 & 12.17 & 12.08 & 12.08 & $18 / 3 / 18$ & 12 \\
\hline SRAT Target Boil-up Rate (g/min) & 3.67 & 3.88 & 3.88 & 3.88 & 3.88 & $3.3-3.6$ & $3.3-3.6$ \\
\hline SRAT Air Purge on System (slm) & 0.514 & 0.544 & 0.544 & 0.544 & 0.544 & 0.498 & 0.498 \\
\hline SRAT Helium Purge on System $(\mathrm{sccm})$ & 2.57 & 2.72 & 2.72 & 2.72 & 2.72 & 2.49 & 2.49 \\
\hline Initial Sludge $\mathrm{pH}$ with Trim Chemicals & 11.64 & 11.14 & 11.52 & 10.45 & 10.96 & 11.56 & 11.44 \\
\hline Minimum $\mathrm{pH}$ during SRAT & 4.33 & 4.63 & 4.41 & 4.68 & 4.32 & 4.82 & 4.38 \\
\hline pH at End of SRAT (at boiling) & 4.94 & 6.64 & 5.04 & 6.26 & 5.72 & $6.55 / 6.31 / 6.62$ & 5.51 \\
\hline DWPF SME Scale Factor $(56,600$ lbs basis $)$ & 10630 & 10161 & 10082 & 10538 & 10578 & 10273 & 10113 \\
\hline SME Air Purge (sccm) & 0.187 & 0.189 & 0.191 & 0.187 & 0.185 & 0.186 & 0.184 \\
\hline SME He Purge $(\mathrm{sccm})$ & 0.93 & 0.95 & 0.95 & 0.93 & 0.92 & 0.93 & 0.92 \\
\hline SME Target Boil-up Rate (g/min) & 3.56 & 3.85 & 3.47 & 1.7 & 1.5 & $1.3-1.5$ & $1.3-1.5$ \\
\hline SME Frit Dewater Target Amount $(\mathrm{g})-1^{\text {st }} 2$ additions & 189.5 & 204.11 & 204.11 & $40 / 203$ & $45.5 / 202$ & $45 / 207$ & $45.02 / 207$ \\
\hline First Frit Condensing/Dewater Time (hrs) & 0.93 & 1.17 & 0.97 & 3.38 & 2.43 & 3.07 & 1.82 \\
\hline Second Frit Condensing/Dewater Time (hrs) & 1.0 & 1.12 & 0.80 & 1.97 & 2.0 & 2.63 & 2.5 \\
\hline SME Final Dewater Target Amount (g) & 717.5 & 880.8 & 787.4 & 961.8 & 927.2 & 909 & 808 \\
\hline Third Frit Dewater Time/Additional Reflux (hrs) & $\mathrm{N} / \mathrm{A}$ & $\mathrm{N} / \mathrm{A}$ & 4 & $9.08 / 10.6$ & $8.95 / 15.22$ & $4.25 / 12$ & $9.03 / 8.1$ \\
\hline Final SME Product $\mathrm{pH}$ (at boiling) & 4.92 & $\mathrm{~N} / \mathrm{A}$ & 5.25 & 6.52 & 6.02 & 6.69 & 5.44 \\
\hline Run Plan Document Number, SRT-GPD-2003- & 00058 & 00063 & 00064 & 00085 & 00086 & 00099 & 00100 \\
\hline
\end{tabular}


Table A - 3: Analyzed Composition of the Starting Sludges

\begin{tabular}{|c|c|c|c|c|c|c|c|}
\hline \multirow[b]{2}{*}{ Parameter } & \multicolumn{3}{|c|}{ Case 6b } & \multicolumn{2}{|c|}{ 20K Nitrite Case } & \multicolumn{2}{|c|}{ 24K Nitrite Case } \\
\hline & Target $^{1}$ & $\begin{array}{c}\text { SB3A-14 } \\
\text { Measured }^{3}\end{array}$ & $\begin{array}{l}\text { SB3A-15/16 } \\
\text { Measured }^{3}\end{array}$ & Target $^{2}$ & Measured $^{3}$ & Target $^{2}$ & Measured \\
\hline \multicolumn{8}{|c|}{ Elemental wt\% in Dried Solids } \\
\hline Al & 5.51 & 5.75 & 5.59 & 6.48 & 6.46 & 5.72 & 5.94 \\
\hline $\mathbf{B a}$ & 0.12 & 0.125 & 0.130 & 0.14 & 0.150 & 0.12 & 0.130 \\
\hline $\mathbf{C a}$ & 1.42 & 1.57 & 1.57 & 1.67 & 1.76 & 1.47 & 1.50 \\
\hline $\mathrm{Cr}$ & 0.21 & 0.427 & 0.437 & 0.17 & 0.348 & 0.12 & 0.232 \\
\hline $\mathbf{C u}$ & 0.09 & 0.076 & 0.055 & 0.10 & 0.099 & 0.09 & 0.086 \\
\hline $\mathbf{F e}$ & 16.2 & 15.8 & 16.1 & 19.1 & 18.3 & 16.8 & 16.2 \\
\hline Gd & 0.02 & 0.001 & 0.026 & 0.03 & 0.031 & 0.02 & 0.026 \\
\hline $\mathbf{K}$ & 0.17 & 0.032 & 0.007 & 0.20 & 0.051 & 0.12 & 0.020 \\
\hline Mg & 1.11 & 1.11 & 1.13 & 1.31 & 1.24 & 1.46 & 1.41 \\
\hline Mn & 3.17 & 3.11 & 3.10 & 3.73 & 3.50 & 3.28 & 3.23 \\
\hline $\mathbf{N a}$ & 16.0 & 15.3 & 14.7 & 12.7 & 11.7 & 15.2 & 14.3 \\
\hline $\mathbf{N i}$ & 0.57 & 0.579 & 0.591 & 0.67 & 0.703 & 0.59 & 0.588 \\
\hline $\mathbf{P b}$ & 0.14 & 0.012 & N/A & 0.17 & 0.023 & 0.07 & 0.184 \\
\hline $\mathbf{S i}$ & 0.49 & 0.653 & 0.647 & 0.57 & 0.760 & 0.50 & 0.646 \\
\hline $\mathbf{Z n}$ & 0.18 & 0.193 & 0.198 & 0.21 & 0.232 & 0.19 & 0.197 \\
\hline $\mathbf{Z r}$ & 0.10 & 0.316 & 0.317 & 0.11 & 0.365 & 0.10 & 0.313 \\
\hline \multicolumn{8}{|c|}{ Anions (mg/kg slurry) } \\
\hline Nitrite & 26790 & 26100 & 27100 & 20000 & 21500 & 24000 & 24300 \\
\hline Nitrate & 20050 & 20200 & 21100 & 16000 & 15900 & 21000 & 22400 \\
\hline
\end{tabular}

Table A - 4: Other Measured Properties for Starting Adjusted Sludges

\begin{tabular}{|c|c|c|c|c|}
\hline \multirow[t]{2}{*}{ Parameter } & \multicolumn{2}{|c|}{ Case 6b } & 20K Case & 24K Case \\
\hline & SB3A-14 & SB3A-15/16 & SB3A-17/18 & SB3A-19/20 \\
\hline Oxalate (mg/kg slurry) & 1950 & 2820 & 2680 & 3000 \\
\hline Sulfate (mg/kg slurry) & 2100 & 2250 & 1450 & 2100 \\
\hline Total Solids (wt\%) & 22.0 & 22.6 & 21.6 & 22.4 \\
\hline Insoluble Solids (wt\%) ${ }^{1}$ & 11.8 & 12.2 & 14.0 & 12.8 \\
\hline Soluble Solids (wt\%) ${ }^{1}$ & 10.2 & 10.5 & 7.62 & 9.54 \\
\hline Calcined Solids )wt\%) & 15.0 & 15.0 & 15.0 & 15.3 \\
\hline Sludge Density $(\mathrm{g} / \mathrm{ml})$ & 1.18 & 1.18 & 1.20 & 1.21 \\
\hline Total Inorganic Carbon (ug/ml) ${ }^{2}$ & 1030 & 1180 & 1540 & 810 \\
\hline Total Carbon (ug/ml) ${ }^{2}$ & 1790 & 2880 & 5680 & 1930 \\
\hline pH 7 Titration $(\mathrm{M})^{3}$ & 0.619 & 0.698 & 0.473 & 0.626 \\
\hline pH 5.5 Titration $(\mathrm{M})^{3}$ & 0.910 & 0.936 & N/A & N/A \\
\hline
\end{tabular}

${ }^{1}$ The total, dissolved, and calcined solids were measured on duplicate samples. The insoluble and soluble solids were calculated based on the results. Data represents average of the two measurements.

${ }^{2}$ Performed on single sample that was ground to ensure homogeneity. Analysis of $20 \mathrm{~K}$ samples performed twice. The first value was rejected due to problems in analysis.

${ }^{3}$ Performed in duplicate at a minimum. $\mathrm{pH} 5.5$ not performed for $20 \mathrm{~K}$ and $24 \mathrm{~K}$ cases since only the 7 was need for the acid addition input. 
Table A - 5: Analyzed Composition of the Receipt Samples

\begin{tabular}{|c|c|c|c|c|c|c|c|}
\hline & \multicolumn{3}{|c|}{ Case 6b } & \multicolumn{2}{|c|}{ 20K Nitrite Case } & \multicolumn{2}{|c|}{ 24K Nitrite Case } \\
\hline Element & SB3A-14 & SB3A-15 & SB3A-16 & SB3A-17 & SB3A-18 & SB3A-19 & SB3A-20 \\
\hline \multicolumn{8}{|c|}{ Elemental Wt\% in Dried Solids ${ }^{2}$} \\
\hline Al & & 5.80 & 5.81 & 6.41 & 6.32 & 6.06 & 6.01 \\
\hline $\mathbf{B a}$ & & 0.123 & 0.125 & 0.149 & 0.147 & 0.126 & 0.130 \\
\hline $\mathbf{C a}$ & & 1.53 & 1.48 & 1.68 & 1.78 & 1.65 & 1.65 \\
\hline $\mathrm{Cr}$ & & 0.410 & 0.414 & 0.343 & 0.337 & 0.226 & 0.229 \\
\hline $\mathbf{C u}$ & & 0.067 & 0.072 & 0.083 & 0.091 & 0.074 & 0.080 \\
\hline $\mathbf{F e}$ & & 15.8 & 15.8 & 17.7 & 17.9 & 16.5 & 16.3 \\
\hline Gd & & 0.021 & 0.022 & 0.030 & 0.030 & 0.027 & 0.027 \\
\hline $\mathbf{K}$ & & 0.038 & 0.041 & 0.041 & 0.037 & 0.009 & 0.008 \\
\hline Mg & & 1.05 & 1.09 & 1.26 & 1.25 & 1.39 & 1.43 \\
\hline Mn & & 3.14 & 3.14 & 3.53 & 3.49 & 3.27 & 3.25 \\
\hline $\mathbf{N a}$ & & 14.9 & 14.8 & 11.3 & 11.1 & 13.3 & 13.4 \\
\hline $\mathbf{N i}$ & & 0.586 & 0.587 & 0.668 & 0.676 & 0.627 & 0.625 \\
\hline $\mathbf{P b}$ & & 0.010 & 0.012 & $<0.014$ & $<0.014$ & $<0.007$ & $<0.007$ \\
\hline Si & & 0.008 & 0.023 & 0.798 & 0.783 & 0.911 & 0.733 \\
\hline Ti & & 0.658 & 0.840 & 0.011 & 0.011 & N/A & N/A \\
\hline $\mathbf{Z n}$ & & 0.179 & 0.179 & 0.244 & 0.230 & 0.187 & 0.194 \\
\hline $\mathbf{Z r}$ & & 0.296 & 0.316 & 0.361 & 0.353 & 0.306 & 0.316 \\
\hline \multicolumn{8}{|c|}{ Anion Concentration (mg anion/kg sludge) } \\
\hline Nitrite & 26600 & 25600 & 26000 & 21100 & 20400 & 24300 & 23500 \\
\hline Nitrate & 20300 & 19700 & 19500 & 15800 & 15900 & 21200 & 21000 \\
\hline Oxalate & 2100 & 3770 & 3300 & 2610 & 2830 & 3380 & 2990 \\
\hline Sulfate & 2070 & 2060 & 2040 & 1500 & 1470 & 1960 & 1980 \\
\hline \multicolumn{8}{|l|}{ Solids Analyses (wt\%) } \\
\hline Total Solids & 21.3 & 21.4 & 21.3 & 21.0 & 20.8 & 21.8 & 21.5 \\
\hline Insoluble Solids & 11.4 & 11.7 & 11.5 & 13.8 & 13.5 & 11.8 & 11.6 \\
\hline Soluble Solids & 9.88 & 9.70 & 9.77 & 7.2 & 7.3 & 9.99 & 9.94 \\
\hline Calcined Solids & 14.4 & 14.5 & 14.5 & 14.3 & 14.1 & 14.6 & 14.4 \\
\hline \multicolumn{8}{|c|}{ Other Properties Measured } \\
\hline Sludge Density $(\mathrm{g} / \mathrm{ml})$ & 1.20 & 1.21 & 1.21 & 1.17 & 1.17 & 1.20 & 1.20 \\
\hline pH & 12.6 & 13.2 & 13.4 & 13.5 & 13.9 & 9.89 & 9.90 \\
\hline TIC (ug/ml) & & & & & & 1110 & 879 \\
\hline TC (ug/ml) & & & & & & 2550 & 1600 \\
\hline pH 7 Titration $(\mathbf{M})^{5}$ & & 0.631 & 0.639 & 0.438 & 0.443 & 0.586 & 0.581 \\
\hline pH 5.5 Titration $(\mathbf{M})^{5}$ & & 0.880 & 0.887 & 0.662 & 0.663 & 0.896 & 0.902 \\
\hline
\end{tabular}

Only select analyses were performed on the sample since additional runs were performed and the overall test was not successful.

${ }^{2}$ Chemical analysis was performed on two aliquots removed from the submitted sample. Results represent an average of the duplicate analyses. ${ }^{3}$ Single analysis on a weighted dilution of the sample.

${ }^{4}$ Total, dissolved, and calcined solids were measured and soluble and insoluble solids were calculated.

${ }^{5}$ Performed using an auto-titrator and 30:1 dilution. 
Table A - 6: SRAT/SME Operating Data and Mass Balance for Run SB3A-14

\begin{tabular}{|c|c|c|c|c|}
\hline SB3A-14 & Time & $\begin{array}{c}\text { Mass } \\
\text { Change } \\
\text { (g) }\end{array}$ & Comments & $\begin{array}{c}\text { Running } \\
\text { Mass } \\
\text { Balance (g) }\end{array}$ \\
\hline $\begin{array}{l}\text { Sludge, Trim Chemicals, \& Flush } \\
\text { Water }\end{array}$ & $13: 45$ & 2726.5294 & & 2726.53 \\
\hline SB3A-14 SLUDGE-1 & $14: 45$ & 100 & & 2626.53 \\
\hline Started heating & $\sim 15: 15$ & & & \\
\hline Added 1:10 Antifoam \& Water & $15: 30$ & 10.3 & $5.15 \mathrm{~g}$ of each & 2636.83 \\
\hline Started Nitric Acid & $16: 17$ & & & \\
\hline Stopped Nitric Acid & $17: 06$ & 49.04 & $37.52 \mathrm{ml}, 10.25 \mathrm{M}$ & 2685.87 \\
\hline Started Formic Acid & $17: 15$ & & & \\
\hline Finished Formic Acid & $22: 14$ & 273.11 & $227.02 \mathrm{ml}, 23.22 \mathrm{M}$ & 2958.97 \\
\hline SB3A-14 SRAT-IC-0 & $22: 20$ & 11.23 & & 2947.74 \\
\hline Added 1:10 Antifoam \& Water & $22: 25$ & 20.62 & $10.31 \mathrm{~g}$ of each & 2968.36 \\
\hline Boiling Started & $22: 33$ & & & \\
\hline Dewater finished & $0: 30$ & 333.49 & & 2634.87 \\
\hline SB3A-14 SRAT-IC-1 & $0: 35$ & 11.20 & & 2623.67 \\
\hline SB3A-14 SRAT-IC-3 & $3: 35$ & 11.95 & & 2611.72 \\
\hline SB3A-14 SRAT-IC-6 & $6: 30$ & 12.2073 & & 2599.52 \\
\hline SB3A-14 SRAT-IC-9 & $9: 30$ & 12.29 & & 2587.23 \\
\hline SB3A-14 SRAT-IC-12 & $12: 30$ & 11.87 & & 2575.36 \\
\hline SRAT complete & $12: 30$ & & Estimated SRAT Product with 3\% loss & 2496.56 \\
\hline SB3A-14 SRAT-Product-1 & & 112.32 & & 2463.04 \\
\hline \multicolumn{5}{|l|}{ Started SME } \\
\hline Added 1:10 Antifoam \& Water & $12: 38$ & 5.00 & $2.5 \mathrm{~g}$ of each & 2580.36 \\
\hline First frit addition & $12: 43$ & 189.52 & & 2769.88 \\
\hline First formic addition & $12: 50$ & 2.84 & & 2772.72 \\
\hline First frit water addition & $12: 51$ & 186.68 & & 2959.40 \\
\hline First frit boiling started & 13:08 & & & \\
\hline First frit dewater complete & 14:04 & 189.58 & & 2769.82 \\
\hline Second frit addition & $14: 14$ & 189.52 & & 2959.34 \\
\hline Second formic addition & $14: 14$ & 2.84 & & 2962.18 \\
\hline Second frit water addition & $14: 14$ & 186.68 & & 3148.86 \\
\hline Second frit boiling started & $14: 35$ & & & \\
\hline Second frit dewater complete & $15: 35$ & 189.5 & & 2959.36 \\
\hline Third frit addition & $15: 45$ & 189.52 & & 3148.88 \\
\hline Third formic addition & $15: 45$ & 2.84 & & 3151.72 \\
\hline Third frit water addition & $15: 45$ & 186.68 & & 3338.40 \\
\hline Third frit boiling started & $16: 05$ & & & \\
\hline Third frit dewater complete & $17: 07$ & 198.1 & $\begin{array}{r}\text { SME was stopped since } \mathrm{H}_{2} \text { already } \\
\text { exceeded limit. }\end{array}$ & 3140.30 \\
\hline SME Final product & & 2873.4 & Delta & 266.90 \\
\hline MWWT final & & 166.2 & initial $165 \mathrm{~g}$ & \\
\hline SME-FAVC-1 & & 22.72 & Estimated SME Final & 3105.08 \\
\hline SME mass on kettle, blades, etc. & & 11.3 & Delta' & 231.68 \\
\hline
\end{tabular}


Table A - 7: SRAT/SME Operating Data and Mass Balance for Run SB3A-15

\begin{tabular}{|c|c|c|c|c|}
\hline SB3A-15 & Time & $\begin{array}{c}\text { Mass } \\
\text { Change (g) }\end{array}$ & Comments & $\begin{array}{c}\text { Running Mass } \\
\text { Balance (g) }\end{array}$ \\
\hline $\begin{array}{l}\text { Sludge, Trim Chemicals, \& Flush } \\
\text { Water }\end{array}$ & & 2900.0573 & & 2900.06 \\
\hline SB3A-15 RECEIPT-TITRN & $17: 35$ & 29.76 & & 2870.30 \\
\hline SB3A-15 RECEIPT-1 & $17: 35$ & 117.42 & & 2752.88 \\
\hline Started heating & $6: 45$ & & & \\
\hline Added 1:10 Antifoam \& Water & $7: 10$ & 11 & $5.50 \mathrm{~g}$ of each & 2763.88 \\
\hline Started Nitric Acid & 8:08 & & & \\
\hline Stopped Nitric Acid & $8: 20$ & 12.822 & $9.81 \mathrm{ml}, 10.25 \mathrm{M}$ & 2776.70 \\
\hline Started Formic Acid & $8: 24$ & & & \\
\hline Finished Formic Acid & $12: 15$ & 225.31 & $187.76 \mathrm{ml}, 22.75 \mathrm{M}$ & 3002.01 \\
\hline SB3A-15 SRAT-IC-0 & $12: 26$ & 11.98 & & 2990.03 \\
\hline Added 1:10 Antifoam \& Water & $12: 35$ & 22 & $11.0 \mathrm{~g}$ of each & 3012.03 \\
\hline Boiling Started & $12: 43$ & & & \\
\hline Dewater finished & $13: 52$ & 208 & & 2804.03 \\
\hline SB3A-15 SRAT-IC-1 & $13: 55$ & 14.65 & & 2789.38 \\
\hline SB3A-15 SRAT-IC-3 & $17: 00$ & 12.75 & & 2776.63 \\
\hline SB3A-15 SRAT-IC-6 & $20: 00$ & 15.3 & & 2761.33 \\
\hline SB3A-15 SRAT-IC-9 & $23: 00$ & 11.23 & & 2750.10 \\
\hline SB3A-15 SRAT-IC-12 & $2: 00$ & 11.85 & & 2738.25 \\
\hline SRAT complete & $2: 00$ & & $\begin{array}{l}\text { Estimated SRAT Product with } \\
3 \% \text { loss and FAVC }\end{array}$ & 2630.16 \\
\hline SB3A-15 SRAT-Product-1 & $2: 10$ & 116.17 & & 2622.08 \\
\hline SB3A-15 SRAT-FAVC-1 & $2: 14$ & 25.5 & & 2596.58 \\
\hline SB3A-15 SRAT-MWWT & $2: 10$ & 11.17 & & 2585.41 \\
\hline \multicolumn{5}{|l|}{ SME Started } \\
\hline Added 1:10 Antifoam \& Water & $2: 43$ & 5.46 & $2.73 \mathrm{~g}$ of each & 2590.87 \\
\hline First frit addition & $2: 45$ & 204.11 & & 2794.98 \\
\hline First formic addition & $2: 45$ & 3.06 & & 2798.04 \\
\hline First frit water addition & $2: 45$ & 201.05 & & 2999.09 \\
\hline First frit boiling started & $3: 30$ & & & \\
\hline $\begin{array}{l}\text { First frit dewater complete - } \\
\text { SB3A-15 SME-SMECT-1 }\end{array}$ & $4: 40$ & 204.11 & & 2794.98 \\
\hline Second frit addition & $5: 03$ & 204.11 & & 2999.09 \\
\hline Second formic addition & 5:03 & 3.06 & & 3002.15 \\
\hline Second frit water addition & $5: 03$ & 201.05 & & 3203.20 \\
\hline Second frit boiling started & $5: 30$ & & & \\
\hline Second frit dewater complete & $6: 37$ & 204.11 & & 2999.09 \\
\hline Third frit addition & $6: 50$ & 204.11 & & 3203.20 \\
\hline Third formic addition & $6: 50$ & 3.06 & & 3206.26 \\
\hline Third frit water addition & $6: 50$ & 201.05 & & 3407.31 \\
\hline Third frit boiling started & $7: 20$ & & & \\
\hline Third frit dewater & & 576.8 & Estimated mass & 2830.51 \\
\hline
\end{tabular}


Table A - 8: SRAT/SME Operating Data and Mass Balance for Run SB3A-16

\begin{tabular}{|c|c|c|c|c|}
\hline SB3A-16 & Time & $\begin{array}{c}\text { Mass } \\
\text { Change (g) }\end{array}$ & Comments & $\begin{array}{c}\text { Running Mass } \\
\text { Balance (g) }\end{array}$ \\
\hline $\begin{array}{l}\text { Sludge, Trim Chemicals, \& } \\
\text { Flush Water }\end{array}$ & & 2900.0882 & & 2900.09 \\
\hline SB3A-16 RECEIPT-TITRN & $18: 25$ & 29.58 & & 2870.50 \\
\hline SB3A-16 RECEIPT-1 & $18: 25$ & 117.38 & & 2753.12 \\
\hline Started heating & $5: 45$ & & & \\
\hline Added 1:10 Antifoam \& Water & $6: 15$ & 11.00 & $5.50 \mathrm{~g}$ of each & 2764.12 \\
\hline Started Nitric Acid & $6: 58$ & & & \\
\hline Stopped Nitric Acid & $7: 50$ & 53.87454 & $41.22 \mathrm{ml}, 10.25 \mathrm{M}$ & 2817.99 \\
\hline Started Formic Acid & $8: 05$ & & & \\
\hline Finished Formic Acid & $12: 42$ & 272.892 & $227.41 \mathrm{ml}, 22.75 \mathrm{M}$ & 3090.89 \\
\hline SB3A-16 SRAT-IC-0 & $12: 52$ & 12.55 & & 3078.34 \\
\hline Added 1:10 Antifoam \& Water & $13: 02$ & 22 & $11.0 \mathrm{~g}$ of each & 3100.34 \\
\hline Boiling Started & $13: 17$ & & & \\
\hline Dewater finished & $14: 40$ & 277.09 & & 2823.25 \\
\hline SB3A-16 SRAT-IC-1 & $14: 50$ & 12.71 & & 2810.54 \\
\hline SB3A-16 SRAT-IC-3 & $17: 50$ & 12.69 & & 2797.85 \\
\hline SB3A-16 SRAT-IC-6 & $20: 50$ & 11.7 & & 2786.15 \\
\hline SB3A-16 SRAT-IC-9 & $23: 50$ & 11.3 & & 2774.85 \\
\hline SB3A-16 SRAT-IC-12 & $2: 50$ & 10.43 & & 2764.42 \\
\hline SRAT complete & $2: 50$ & & $\begin{array}{l}\text { Estimated SRAT Product with } \\
3 \% \text { loss and FAVC }\end{array}$ & 2659.14 \\
\hline SB3A-16 SRAT-Product-1 & $3: 00$ & 115.49 & & 2648.93 \\
\hline SB3A-16 SRAT-FAVC-1 & $3: 05$ & 22.69 & & 2626.24 \\
\hline SB3A-16 SRAT-MWWT & $3: 10$ & 12.25 & & 2613.99 \\
\hline \multicolumn{5}{|l|}{$\begin{array}{ll}\text { SME Started } \\
\end{array}$} \\
\hline Added 1:10 Antifoam \& Water & $3: 11$ & 5.5 & $2.75 \mathrm{~g}$ of each & 2619.49 \\
\hline First frit addition & $3: 15$ & 204.11 & & 2823.60 \\
\hline First formic addition & $3: 15$ & 3.06 & & 2826.66 \\
\hline First frit water addition & $3: 15$ & 201.05 & & 3027.71 \\
\hline First frit boiling started & $3: 47$ & & & \\
\hline $\begin{array}{l}\text { First frit dewater complete - } \\
\text { SB3A-16 SME-SMECT-1 }\end{array}$ & $4: 45$ & 204.5 & & 2823.58 \\
\hline Second frit addition & $5: 00$ & 204.11 & & 3027.69 \\
\hline Second formic addition & $5: 00$ & 3.06 & & 3030.75 \\
\hline Second frit water addition & $5: 00$ & 201.05 & & 3231.75 \\
\hline Second frit boiling started & $5: 17$ & & & \\
\hline Second frit dewater complete & $6: 05$ & 204 & & 3027.75 \\
\hline Third frit addition & $6: 30$ & 204.11 & & 3231.86 \\
\hline Third formic addition & $6: 30$ & 3.06 & & 3234.92 \\
\hline Third frit water addition & $6: 30$ & 201.05 & & 3435.92 \\
\hline Third frit boiling started & $6: 53$ & & & \\
\hline Third frit dewater complete & $10: 30$ & 787.4 & & 2648.52 \\
\hline SME Complete/Final product & & 2451.9 & Delta & 196.62 \\
\hline MWWT final & & 162.9 & initial $177.0 \mathrm{~g}$ & \\
\hline SME-FAVC-1 & & 2.7 & Estimated SME Final & 2619.22 \\
\hline SME mass on kettle, blades, etc. & & 40.7 & Delta' & 167.32 \\
\hline
\end{tabular}


Table A - 9: SRAT/SME Operating Data and Mass Balance for Run SB3A-17

\begin{tabular}{|c|c|c|c|c|}
\hline SB3A-17 & Time & $\begin{array}{c}\text { Mass } \\
\text { Change (g) }\end{array}$ & Comments & $\begin{array}{c}\text { Running Mass } \\
\text { Balance (g) }\end{array}$ \\
\hline $\begin{array}{l}\text { Sludge, Trim Chemicals, \& } \\
\text { Flush Water }\end{array}$ & & 2949.9687 & & 2949.97 \\
\hline SB3A-17 RECEIPT-TITRN & $2: 45$ & 24.11 & & 2925.86 \\
\hline SB3A-17 RECEIPT-1 & $2: 45$ & 105.92 & & 2819.94 \\
\hline Started heating & $10: 45$ & & & \\
\hline Added 1:10 Antifoam \& Water & $10: 58$ & 11.2 & $5.60 \mathrm{~g}$ of each & 2831.14 \\
\hline Started Formic Acid & $13: 14$ & & & \\
\hline Finished Formic Acid & $16: 23$ & 185.83 & $154.34 \mathrm{ml}, 23.42 \mathrm{M}$ & 3016.96 \\
\hline SB3A-17 SRAT-IC-0 & $16: 23$ & 10.24 & & 3006.72 \\
\hline Added 1:10 Antifoam \& Water & $16: 32$ & 22.4 & $11.20 \mathrm{~g}$ of each & 3029.12 \\
\hline Boiling Started & $16: 43$ & & & \\
\hline Dewater finished & $17: 45$ & 191.2 & & 2837.92 \\
\hline SB3A-17 SRAT-IC-1 & $17: 47$ & 12.84 & & 2825.08 \\
\hline SB3A-17 SRAT-IC-3 & $20: 47$ & 11.59 & & 2813.49 \\
\hline SB3A-17 SRAT-IC-6 & $23: 47$ & 12.85 & & 2800.64 \\
\hline SB3A-17 SRAT-IC-9 & $2: 47$ & 11.41 & & 2789.23 \\
\hline SB3A-17 SRAT-IC-12 & $5: 45$ & 12.81 & & 2776.42 \\
\hline SRAT complete & $5: 49$ & & $\begin{array}{l}\text { Estimated SRAT Product with } \\
3 \% \text { loss and FAVC and MWWT }\end{array}$ & 2689.97 \\
\hline SB3A-17 SRAT-Product-1 & $5: 47$ & 100.94 & & 2675.48 \\
\hline SB3A-17 SRAT-Product-2 & $5: 47$ & 21.25 & & 2654.23 \\
\hline SB3A-17 SRAT-FAVC & $5: 51$ & 6.51 & & 2647.72 \\
\hline SB3A-17 SRAT-MWWT & $6: 10$ & 152.27 & 156.92 initial mass & 2652.37 \\
\hline \multicolumn{5}{|l|}{ SME started } \\
\hline Added 1:10 Antifoam \& Water & $5: 58$ & 5.44 & $2.72 \mathrm{~g}$ of each & 2657.81 \\
\hline First frit addition & $6: 25$ & 203 & & 2860.81 \\
\hline First formic addition & $6: 25$ & 3.04 & & 2863.85 \\
\hline First frit water addition & $6: 25$ & 200 & & 3063.85 \\
\hline First frit boiling started & $6: 47$ & & & \\
\hline $\begin{array}{l}\text { First frit dewater complete - } \\
\text { SB3A-17 SME-SMECT-1 }\end{array}$ & $10: 10$ & 39.77 & & 3024.08 \\
\hline Second frit addition & $10: 42$ & 203 & & 3227.08 \\
\hline Second formic addition & $10: 42$ & 3.02 & & 3230.10 \\
\hline Second frit water addition & $10: 42$ & 200 & & 3430.10 \\
\hline Second frit boiling started & $11: 05$ & & & \\
\hline $\begin{array}{l}\text { Second frit dewater complete - } \\
\text { SB3A-17 SME-SMECT-2 }\end{array}$ & $13: 03$ & 203 & & 3227.10 \\
\hline Third frit addition & $13: 27$ & 203 & & 3430.10 \\
\hline Third formic addition & $13: 27$ & 3.02 & & 3433.12 \\
\hline Third frit water addition & $13: 27$ & 200 & & 3633.12 \\
\hline Third frit boiling started & $13: 47$ & & & \\
\hline Third frit dewater complete & $22: 52$ & 961.8 & & 2671.32 \\
\hline SME Complete/Final product & $9: 28$ & 2315.6 & Delta & 355.72 \\
\hline MWWT final & $10: 43$ & 151.4812 & filled during SME & 2519.84 \\
\hline SME-FAVC-1 & $10: 35$ & 7.27 & Estimated SME Final & 2439.47 \\
\hline SME mass on kettle, blades, etc. & & 73.1 & Delta' & 128.37 \\
\hline
\end{tabular}

Delta is the difference between the actual weight and the predicted weight.

Delta' takes in the difference in the actual and predicted weights including material lost to the FAVC and MWWT. 
Table A - 10: SRAT/SME Operating Data and Mass Balance for Run SB3A-18

\begin{tabular}{|c|c|c|c|c|}
\hline SB3A-18 & Time & $\begin{array}{c}\text { Mass } \\
\text { Change (g) }\end{array}$ & Comments & $\begin{array}{c}\text { Running Mass } \\
\text { Balance (g) }\end{array}$ \\
\hline $\begin{array}{l}\text { Sludge, Trim Chemicals, \& } \\
\text { Flush Water }\end{array}$ & & 2949.9687 & & 2949.97 \\
\hline SB3A-18 RECEIPT-TITRN & $3: 00$ & 24.98 & & 2924.99 \\
\hline SB3A-18 RECEIPT-1 & $3: 00$ & 107.33 & & 2817.66 \\
\hline Started heating & $13: 35$ & & & \\
\hline Added 1:10 Antifoam \& Water & $10: 50$ & 11.2 & $5.60 \mathrm{~g}$ of each & 2828.86 \\
\hline Started Formic Acid & $11: 30$ & & & \\
\hline Added 1:10 Antifoam \& Water & $13: 13$ & 4.8 & $2.8 \mathrm{~g}$ antifoam, $2 \mathrm{~g} \mathrm{H} 2 \mathrm{O}$ & 2833.66 \\
\hline Finished Formic Acid & $15: 20$ & 221.57 & $184.03 \mathrm{ml}, 23.42 \mathrm{M}$ & 3055.23 \\
\hline SB3A-18 SRAT-IC-0 & $15: 25$ & 11.29 & & 3043.94 \\
\hline Added 1:10 Antifoam \& Water & $15: 36$ & 22.4 & $11.20 \mathrm{~g}$ of each & 3066.34 \\
\hline Boiling Started & $15: 50$ & & & \\
\hline Dewater finished & $16: 48$ & 217.1 & & 2849.24 \\
\hline SB3A-18 SRAT-IC-1 & $16: 49$ & 12.52 & & 2836.72 \\
\hline SB3A-18 SRAT-IC-3 & $19: 49$ & 11.91 & & 2824.81 \\
\hline SB3A-18 SRAT-IC-6 & $22: 49$ & 12.08 & & 2812.73 \\
\hline SB3A-18 SRAT-IC-9 & $1: 49$ & 12.66 & & 2800.07 \\
\hline SB3A-18 SRAT-IC-12 & $4: 49$ & 13.41 & & 2786.66 \\
\hline SRAT complete & $4: 53$ & & $\begin{array}{l}\text { Estimated SRAT Product with } \\
3 \% \text { loss and FAVC and MWWT }\end{array}$ & 2684.71 \\
\hline SB3A-18 SRAT-Product-1 & $4: 51$ & 109.48 & & 2677.18 \\
\hline SB3A-18 SRAT-Product-2 & $4: 52$ & 24.01 & & 2653.17 \\
\hline SB3A-18 SRAT-FAVC & $5: 00$ & 17.61 & & 2635.56 \\
\hline SB3A-18 SRAT-MWWT & $5: 13$ & 165.08 & 165.27 initial mass & 2635.75 \\
\hline \multicolumn{5}{|l|}{ SME started } \\
\hline Added 1:10 Antifoam \& Water & $5: 28$ & 5.44 & $2.71 \mathrm{~g}$ of each & 2641.19 \\
\hline First frit addition & $5: 26$ & 203 & & 2844.19 \\
\hline First formic addition & $5: 26$ & 3.04 & & 2847.23 \\
\hline First frit water addition & $5: 26$ & 200 & & 3047.23 \\
\hline First frit boiling started & $5: 59$ & & & \\
\hline First frit dewater complete & $8: 25$ & 45.5 & & 3001.73 \\
\hline Second frit addition & $8: 44$ & 203 & & 3204.73 \\
\hline Second formic addition & $8: 44$ & 3.02 & & 3207.75 \\
\hline Second frit water addition & $8: 44$ & 200 & & 3407.75 \\
\hline Second frit boiling started & $9: 40$ & & & \\
\hline Second frit dewater complete & $11: 40$ & 202 & & 3205.75 \\
\hline Third frit addition & $12: 10$ & 203 & & 3408.75 \\
\hline Third formic addition & $12: 10$ & 3.02 & & 3411.77 \\
\hline Third frit water addition & $12: 10$ & 200 & & 3611.77 \\
\hline Third frit boiling started & $12: 50$ & & & \\
\hline Third frit dewater complete & $21: 47$ & 927.2 & & 2684.57 \\
\hline SME Complete/Final product & $13: 00$ & 2352.6 & Delta & 331.97 \\
\hline MWWT final & $13: 48$ & 159.285 & filled during SME & \\
\hline SME-FAVC-1 & $13: 37$ & 6.711 & Estimated SME Final & 2484.27 \\
\hline SME mass on kettle, blades, etc. & & 34.3 & Delta' & 131.67 \\
\hline
\end{tabular}


Table A - 11: SRAT/SME Operating Data and Mass Balance for Run SB3A-19

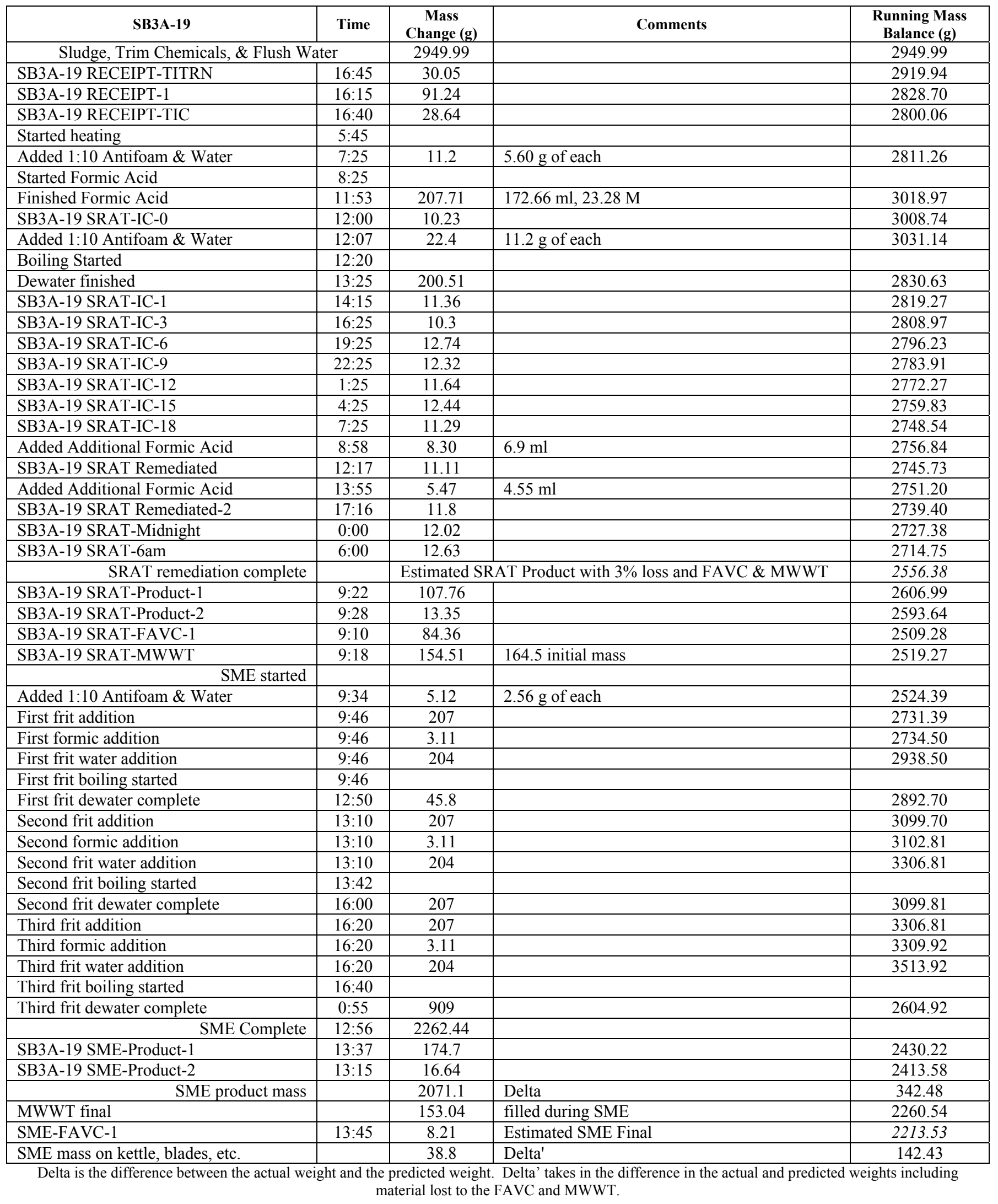


Table A - 12: SRAT/SME Operating Data and Mass Balance for Run SB3A-20

\begin{tabular}{|c|c|c|c|c|}
\hline SB3A-20 & Time & $\begin{array}{c}\text { Mass } \\
\text { Change (g) }\end{array}$ & Comments & $\begin{array}{c}\text { Running Mass } \\
\text { Balance (g) }\end{array}$ \\
\hline \multicolumn{2}{|c|}{ Sludge, Trim Chemicals, \& Flush Water } & 2949.989 & & 2949.99 \\
\hline SB3A-20 RECEIPT-TITRN & $16: 30$ & 30 & & 2919.99 \\
\hline SB3A-20 RECEIPT-1 & $16: 45$ & 90 & & 2829.99 \\
\hline SB3A-20 RECEIPT-TIC & $16: 55$ & 30 & & 2799.99 \\
\hline Started heating & $7: 10$ & & & \\
\hline Added 1:10 Antifoam \& Water & $7: 30$ & 11.2 & $5.60 \mathrm{~g}$ of each & 2811.19 \\
\hline Started Nitric Acid & $8: 02$ & & & \\
\hline Stopped Nitric Acid & $8: 28$ & 26.28 & $20.05 \mathrm{ml}, 10.44 \mathrm{M}$ & 2837.46 \\
\hline Started Formic Acid & $8: 44$ & & & \\
\hline Finished Formic Acid & $12: 52$ & 246.75 & $205.11 \mathrm{ml}, 23.28 \mathrm{M}$ & 3084.21 \\
\hline SB3A-20 SRAT-IC-0 & $12: 55$ & 11.97 & & 3072.24 \\
\hline Added 1:10 Antifoam \& Water & $12: 56$ & 22.4 & $11.2 \mathrm{~g}$ of each & 3094.64 \\
\hline Boiling Started & $13: 11$ & & & \\
\hline Dewater finished & $14: 30$ & 282.39 & & 2812.25 \\
\hline SB3A-20 SRAT-IC-1 & $14: 35$ & 11.98 & & 2800.27 \\
\hline SB3A-20 SRAT-IC-3 & $17: 30$ & 11.72 & & 2788.55 \\
\hline SB3A-20 SRAT-IC-6 & $20: 30$ & 12 & & 2776.55 \\
\hline SB3A-20 SRAT-IC-9 & $23: 30$ & 12.96 & & 2763.59 \\
\hline SB3A-20 SRAT-IC-12 & $2: 30$ & 11.84 & & 2751.75 \\
\hline SRAT complete & $2: 30$ & & $\begin{array}{l}\text { Estimated SRAT Product with 3\% } \\
\text { loss and FAVC and MWWT }\end{array}$ & 2649.91 \\
\hline SB3A-20 SRAT-Product-1 & $2: 35$ & 99.72 & & 2652.03 \\
\hline SB3A-20 SRAT-Product-2 & $2: 36$ & 13.31 & & 2638.72 \\
\hline SB3A-20 SRAT-FAVC & $2: 42$ & 18.4 & & 2620.32 \\
\hline SB3A-20 SRAT-MWWT & $2: 45$ & 166.14 & 166.7 initial mass & 2620.88 \\
\hline \multicolumn{5}{|l|}{\begin{tabular}{|l} 
SME started \\
\end{tabular}} \\
\hline Added 1:10 Antifoam \& Water & $3: 15$ & 5.08 & $2.54 \mathrm{~g}$ of each & 2625.96 \\
\hline First frit addition & $3: 05$ & 207 & & 2832.96 \\
\hline First formic addition & $3: 05$ & 3.11 & & 2836.07 \\
\hline First frit water addition & $3: 05$ & 204 & & 3040.07 \\
\hline First frit boiling started & $3: 35$ & & & \\
\hline First frit dewater complete & $5: 24$ & 45.02 & & 2995.05 \\
\hline Second frit addition & $5: 47$ & 207 & & 3202.05 \\
\hline Second formic addition & $5: 47$ & 3.11 & & 3205.16 \\
\hline Second frit water addition & $5: 47$ & 204 & & 3409.16 \\
\hline Second frit boiling started & $6: 10$ & & & \\
\hline Second frit dewater complete & $8: 40$ & 207 & & 3202.16 \\
\hline Third frit addition & $9: 05$ & 207 & & 3409.16 \\
\hline Third formic addition & $9: 05$ & 3.11 & & 3412.27 \\
\hline Third frit water addition & 9:05 & 204 & & 3616.27 \\
\hline Third frit boiling started & $9: 52$ & & & \\
\hline Third frit dewater complete & $18: 54$ & 808 & & 2808.27 \\
\hline SME Finished & & 2417.93 & Delta & 390.34 \\
\hline SB3A-20 SME-Product-1 & $0: 47$ & 137.22 & & 2671.05 \\
\hline SB3A-20 SME-Product-2 & $0: 45$ & 18.51 & & 2652.54 \\
\hline SB3A-20 SME-FAVC & $0: 49$ & 10.28 & & 2642.26 \\
\hline MWWT & $13: 15$ & 171.1 & filled during SME & 2471.16 \\
\hline SME mass on kettle, blades, etc. & $>13: 00$ & 44.3 & Delta' & 208.96 \\
\hline
\end{tabular}

Delta is the difference between the actual weight and the predicted weight.

Delta' takes in the difference in the actual and predicted weights including material lost to the FAVC and MWWT. 
Figure B - 1: Run SB3A-19 Nitrite Moles Remaining

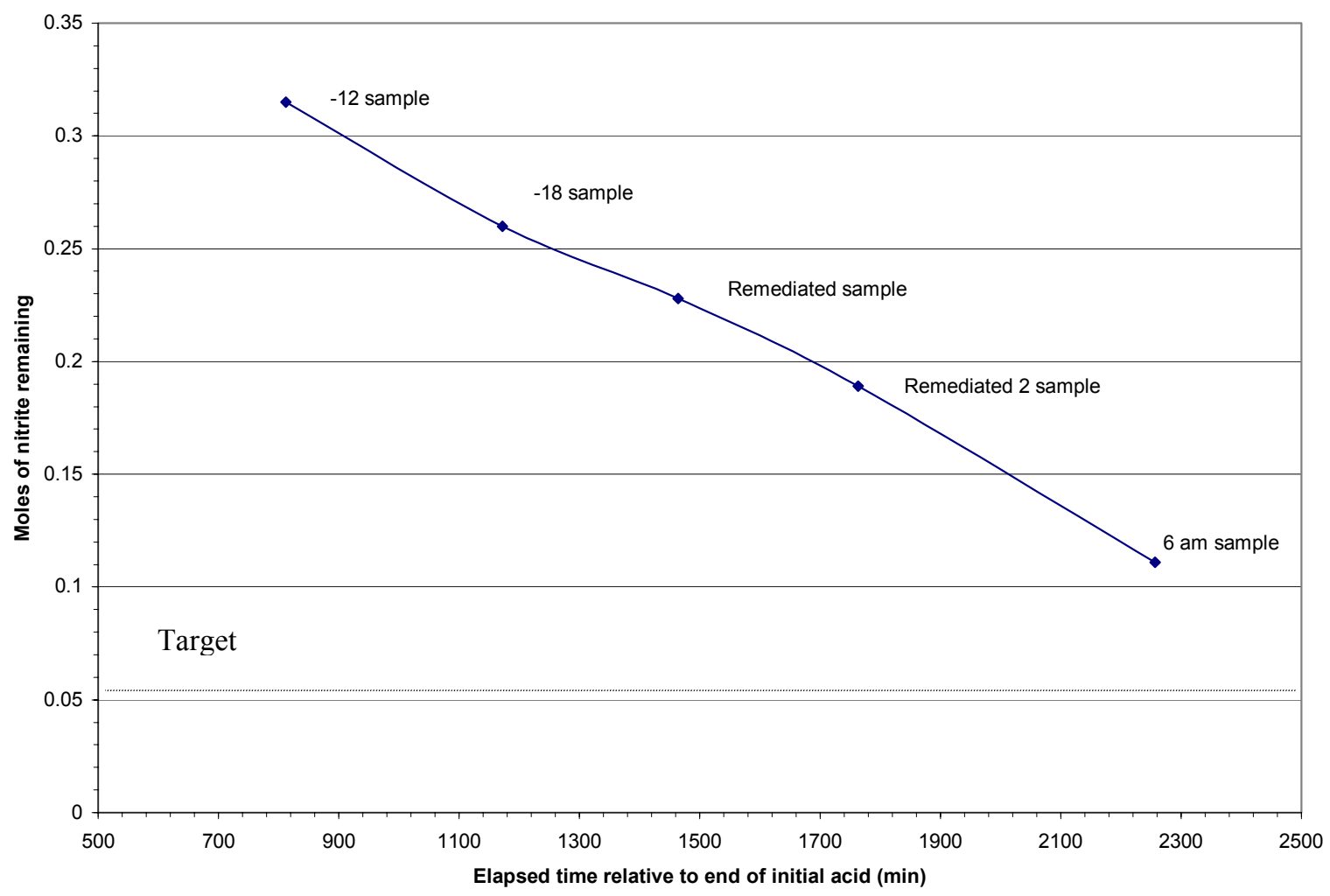

Figure B - 2: SB3A-14 SRAT Cycle GC Data

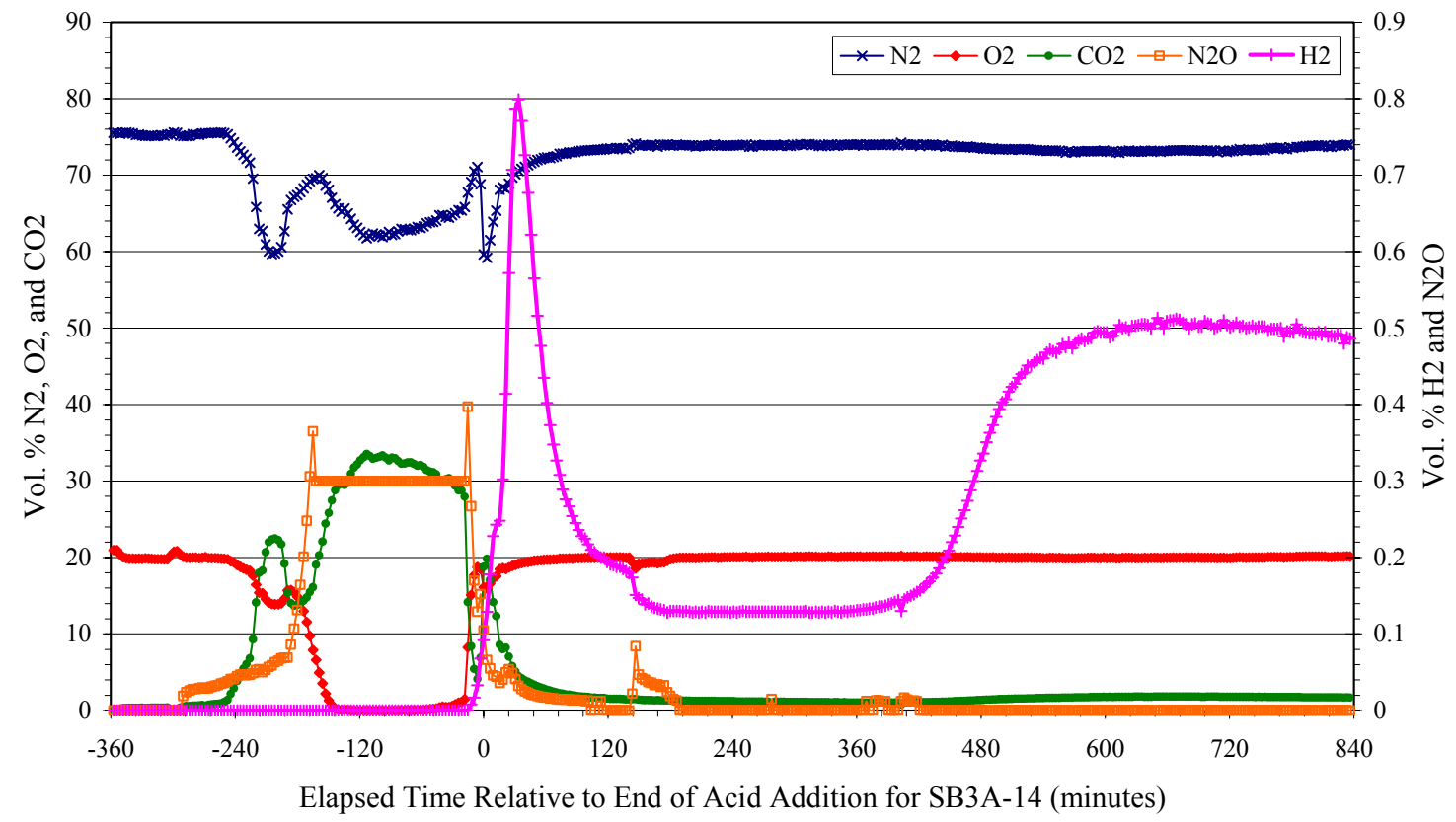


Figure B - 3: SB3A-15 SRAT Cycle GC Data

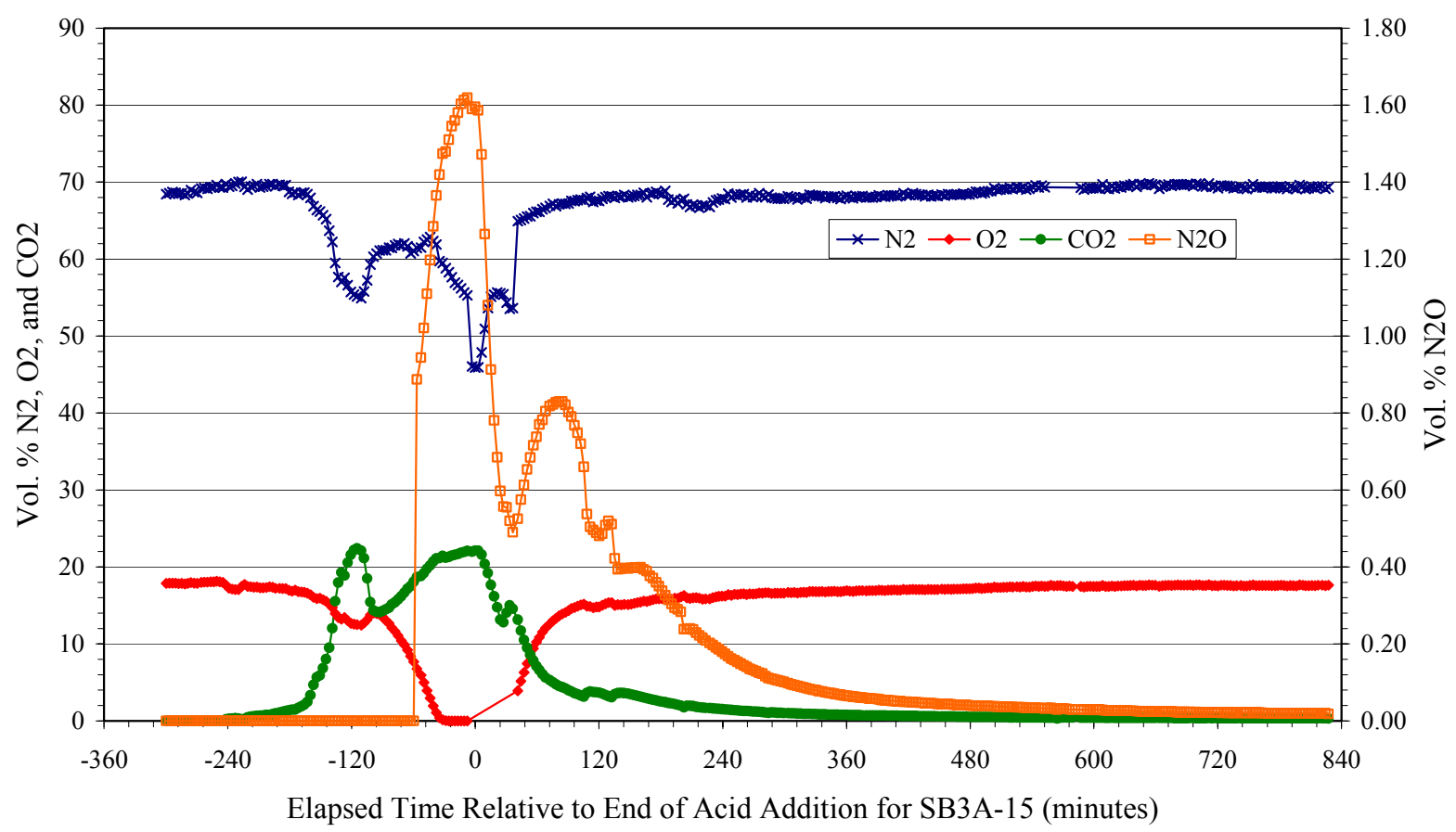

Figure B - 4: SB3A-16 SRAT Cycle GC Data

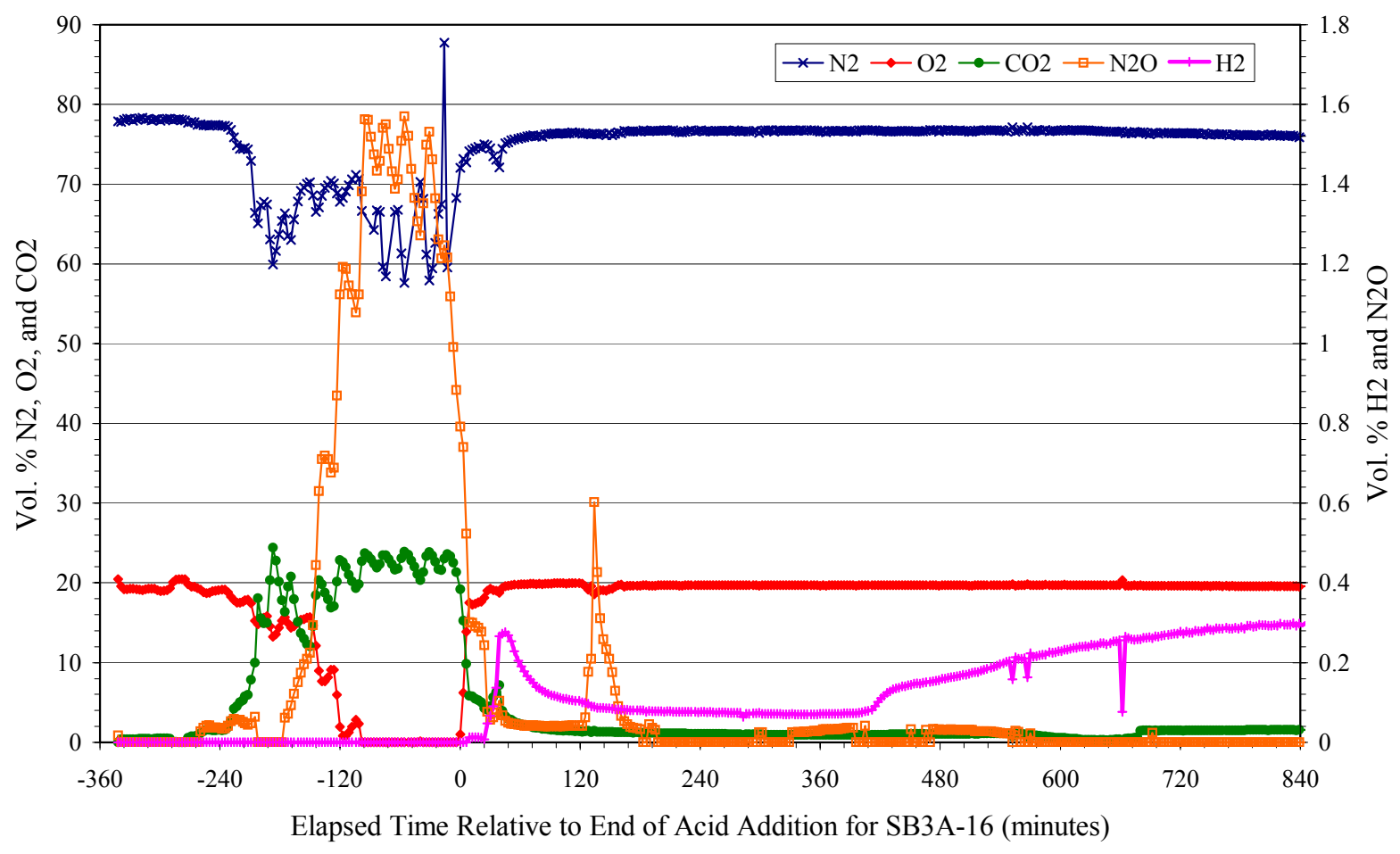


Figure B - 5: SB3A-17 SRAT Cycle GC Data

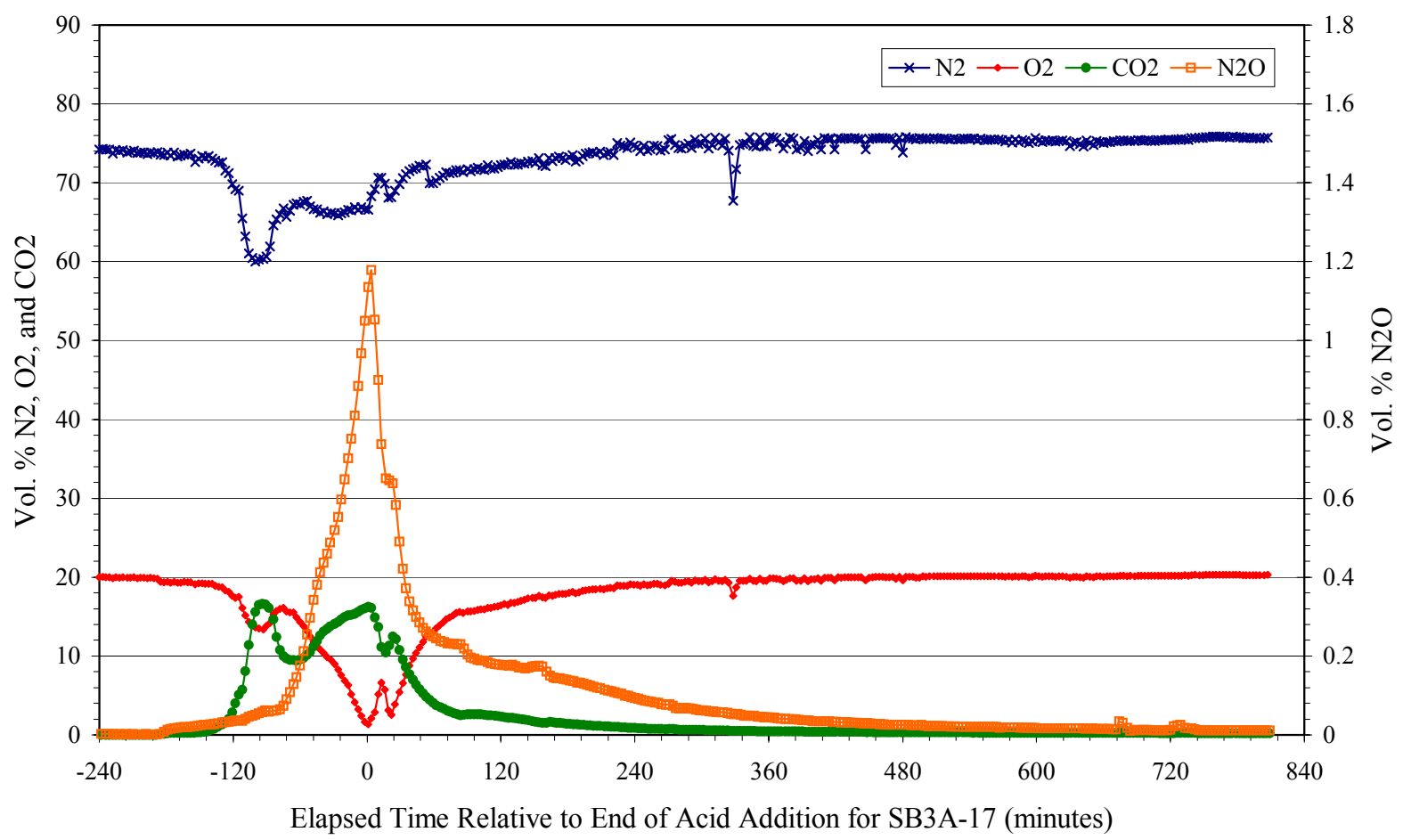

Figure B - 6: SB3A-18 SRAT Cycle GC Data

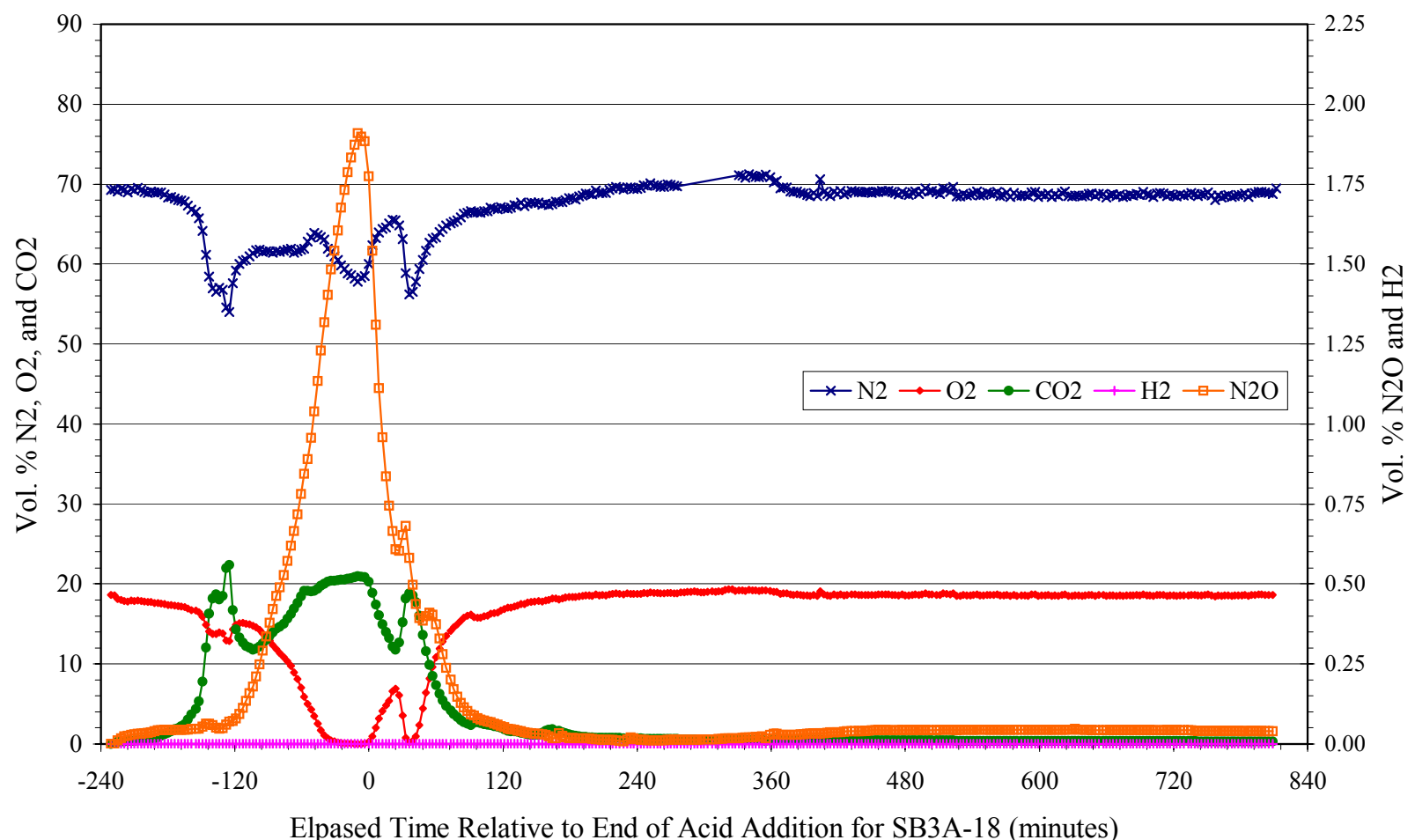


Figure B - 7: SB3A-19 SRAT Cycle GC Data

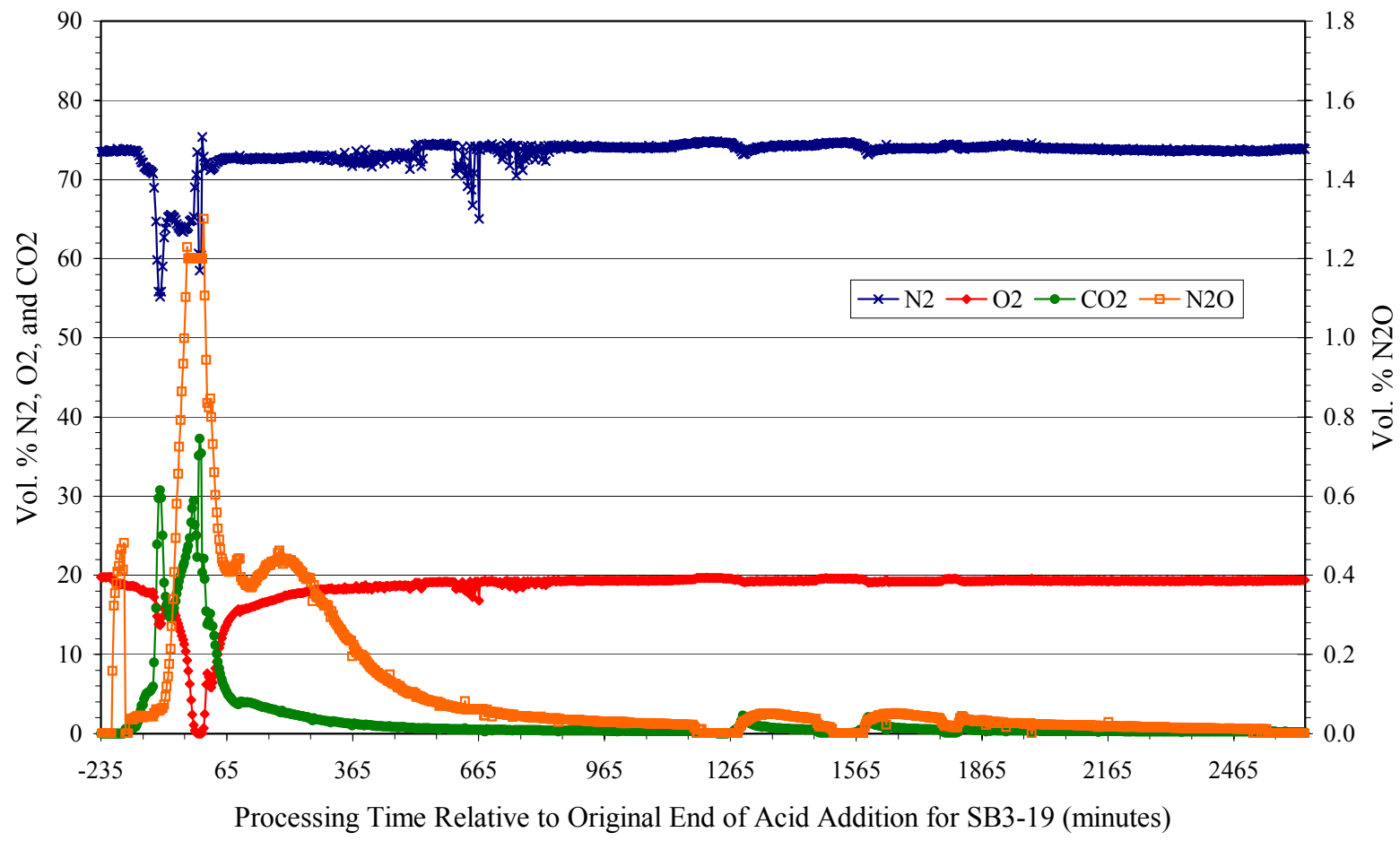

Figure B - 8: SB3A-20 SRAT Cycle GC Data

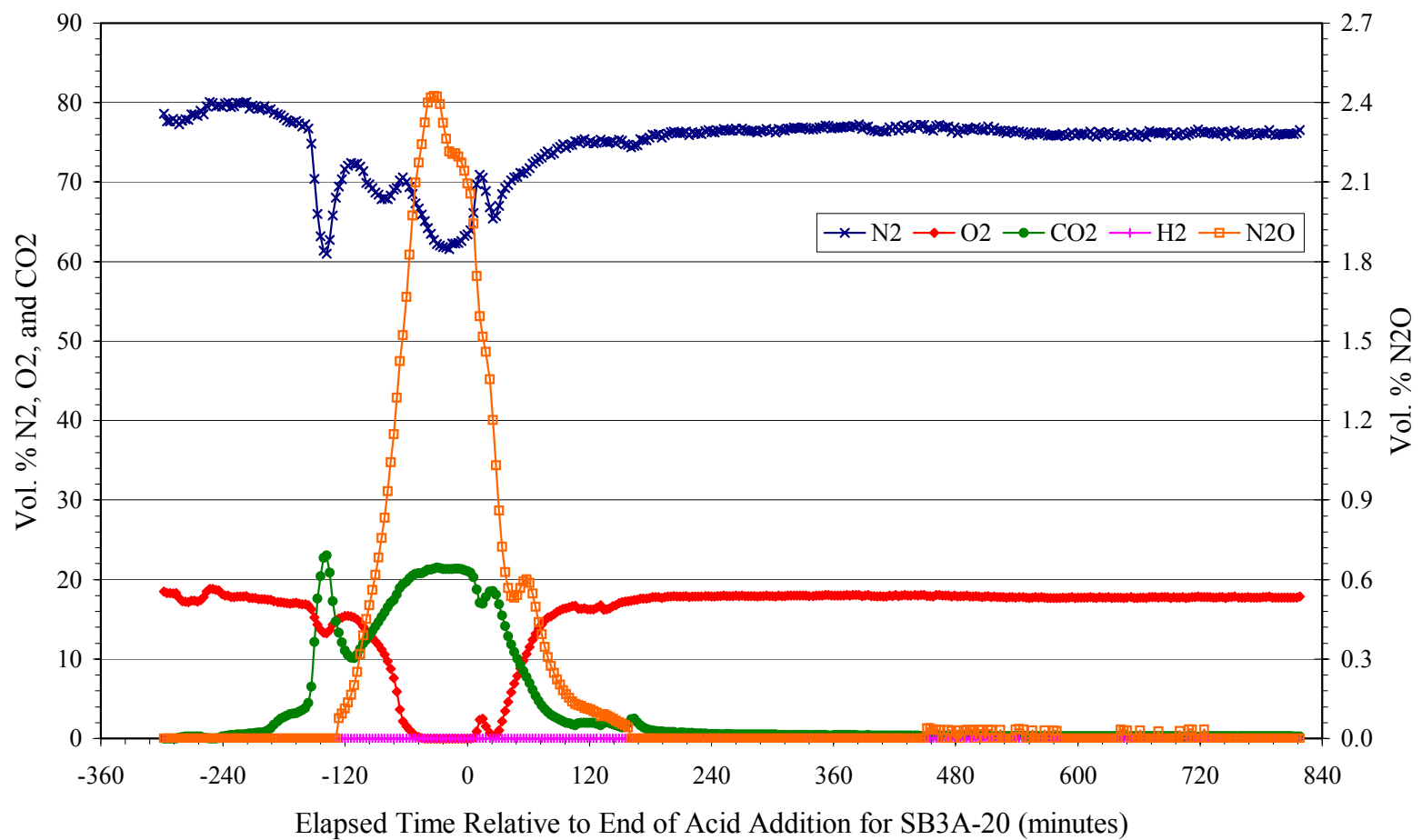

Elapsed Time Relative to End of Acid Addition for SB3A-20 (minutes) 
Figure B - 9: SB3A-14 SME Cycle GC Data

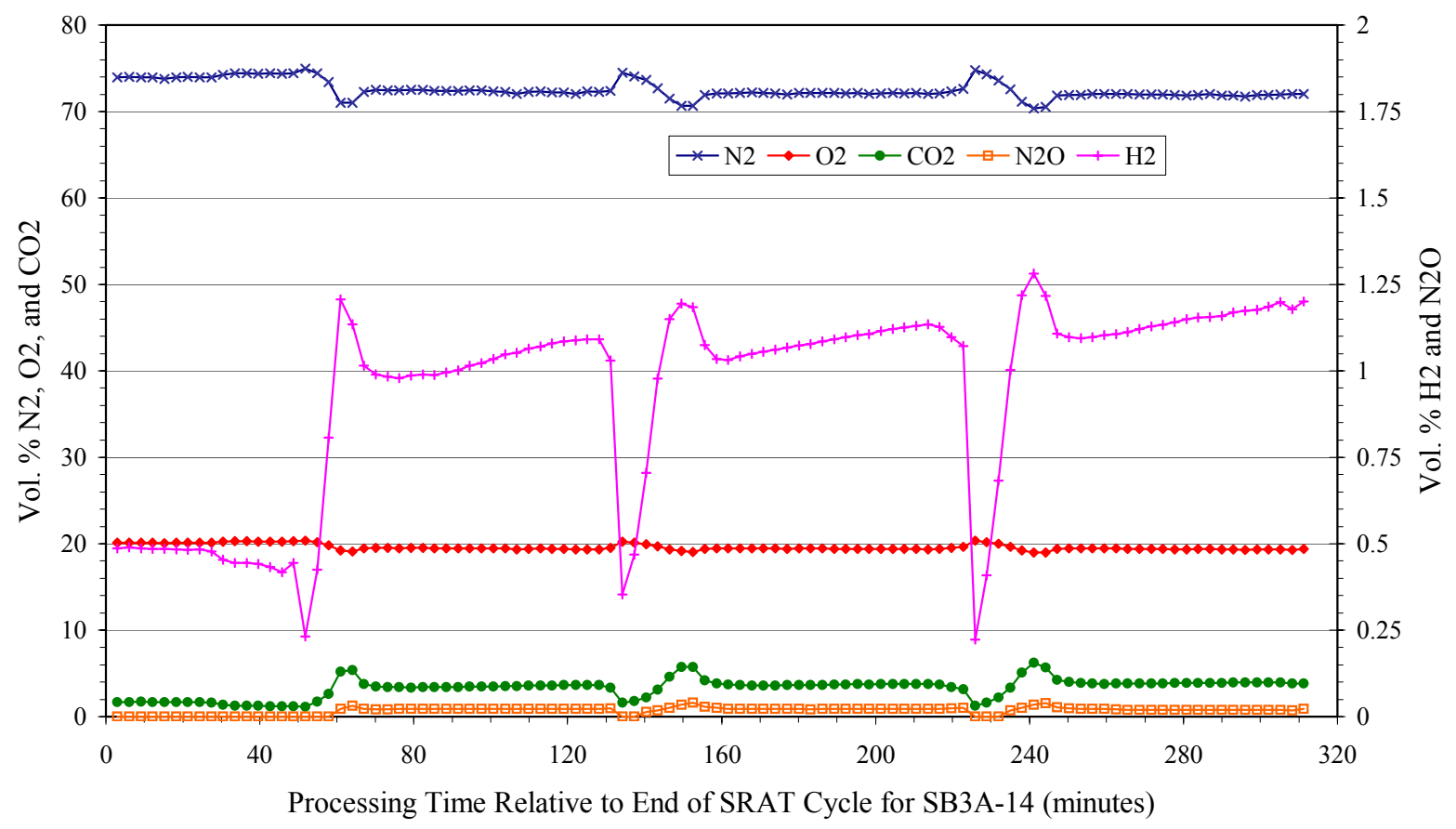

Figure B - 10: SB3A-15 SME Cycle GC Data

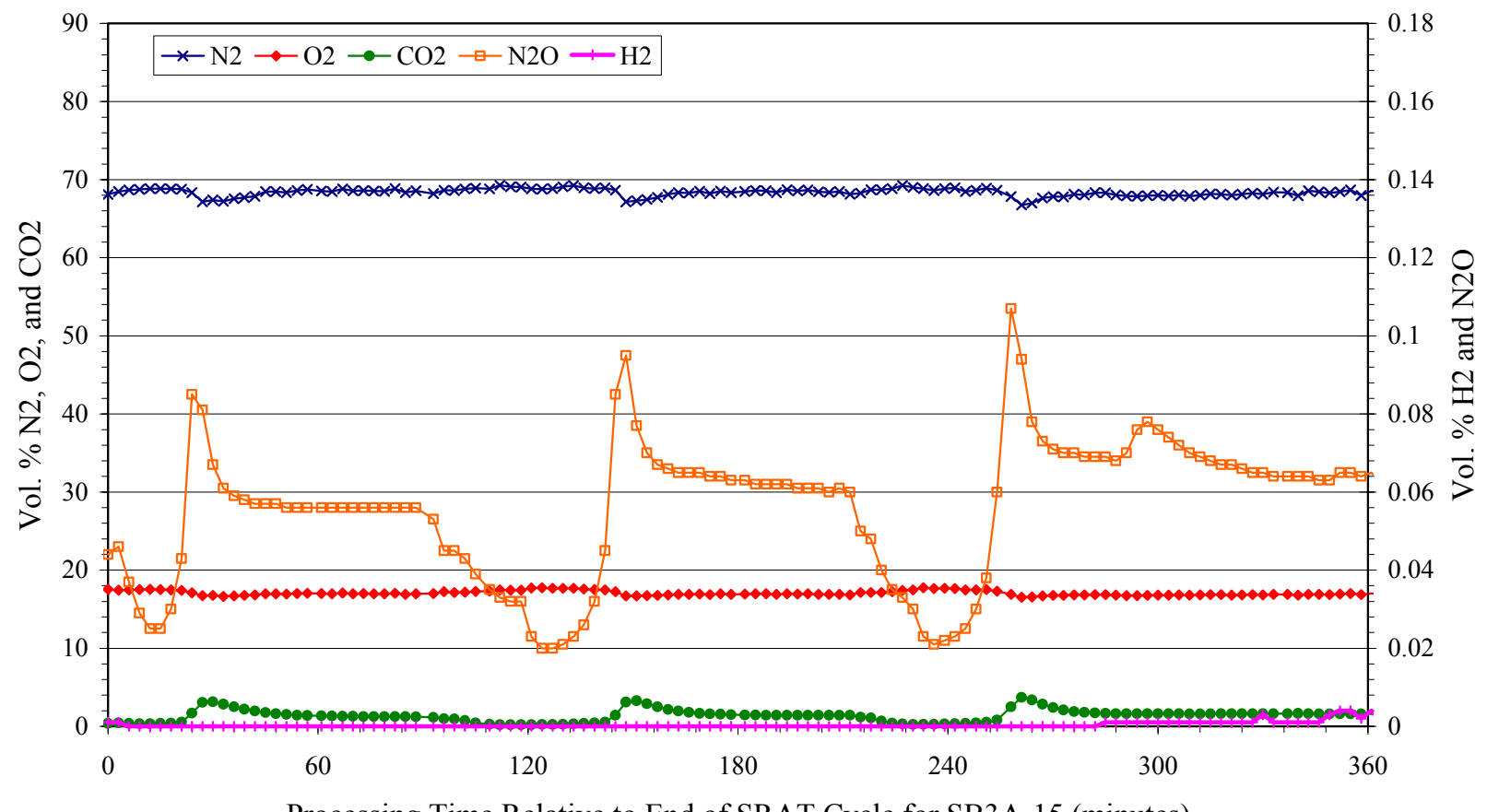

Processing Time Relative to End of SRAT Cycle for SB3A-15 (minutes) 
Figure B - 11: SB3A-16 SME Cycle GC Data

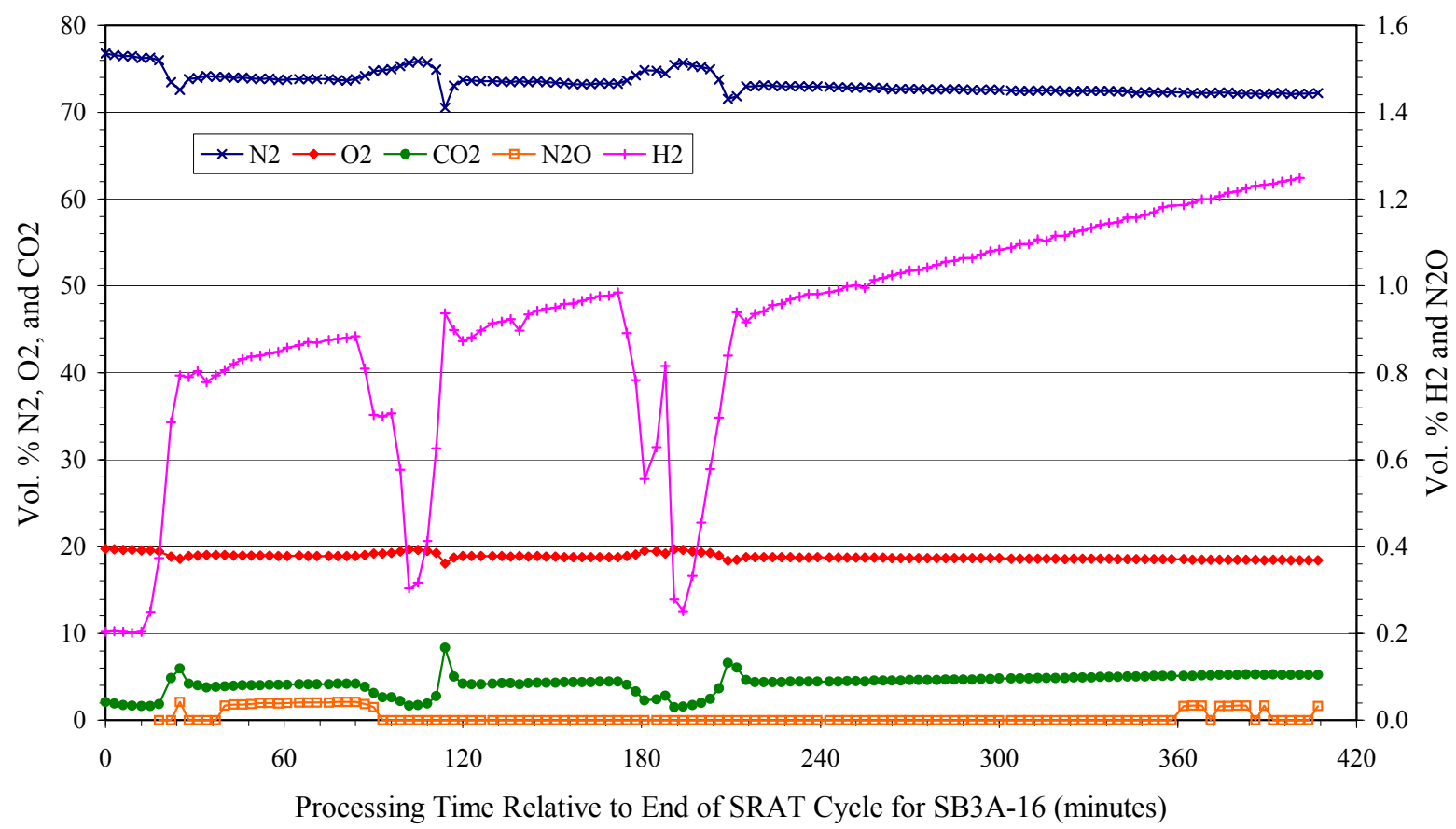

Figure B - 12: SB3A-17 SME Cycle GC Data

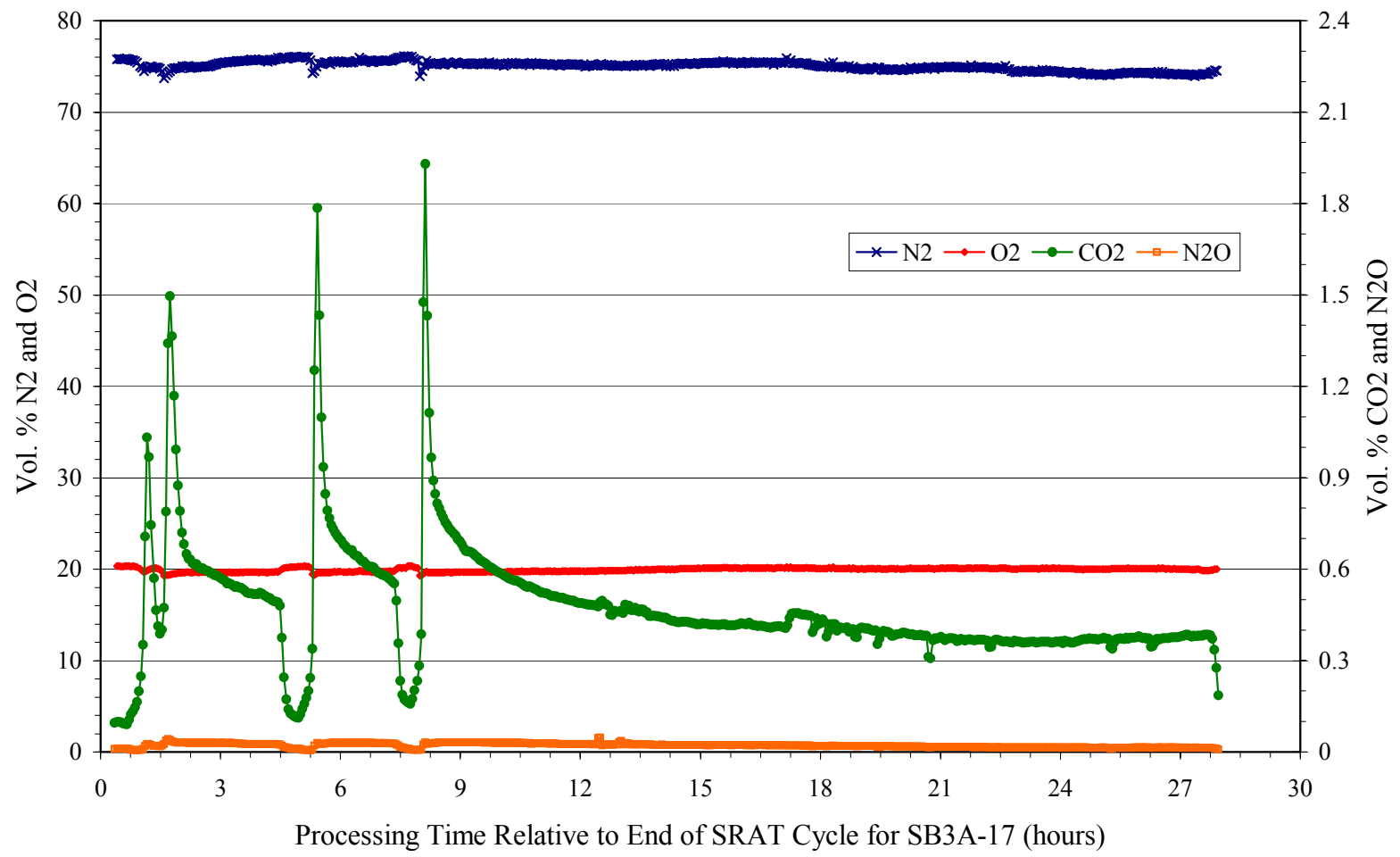


Figure B - 13: SB3A-18 SME Cycle GC Data

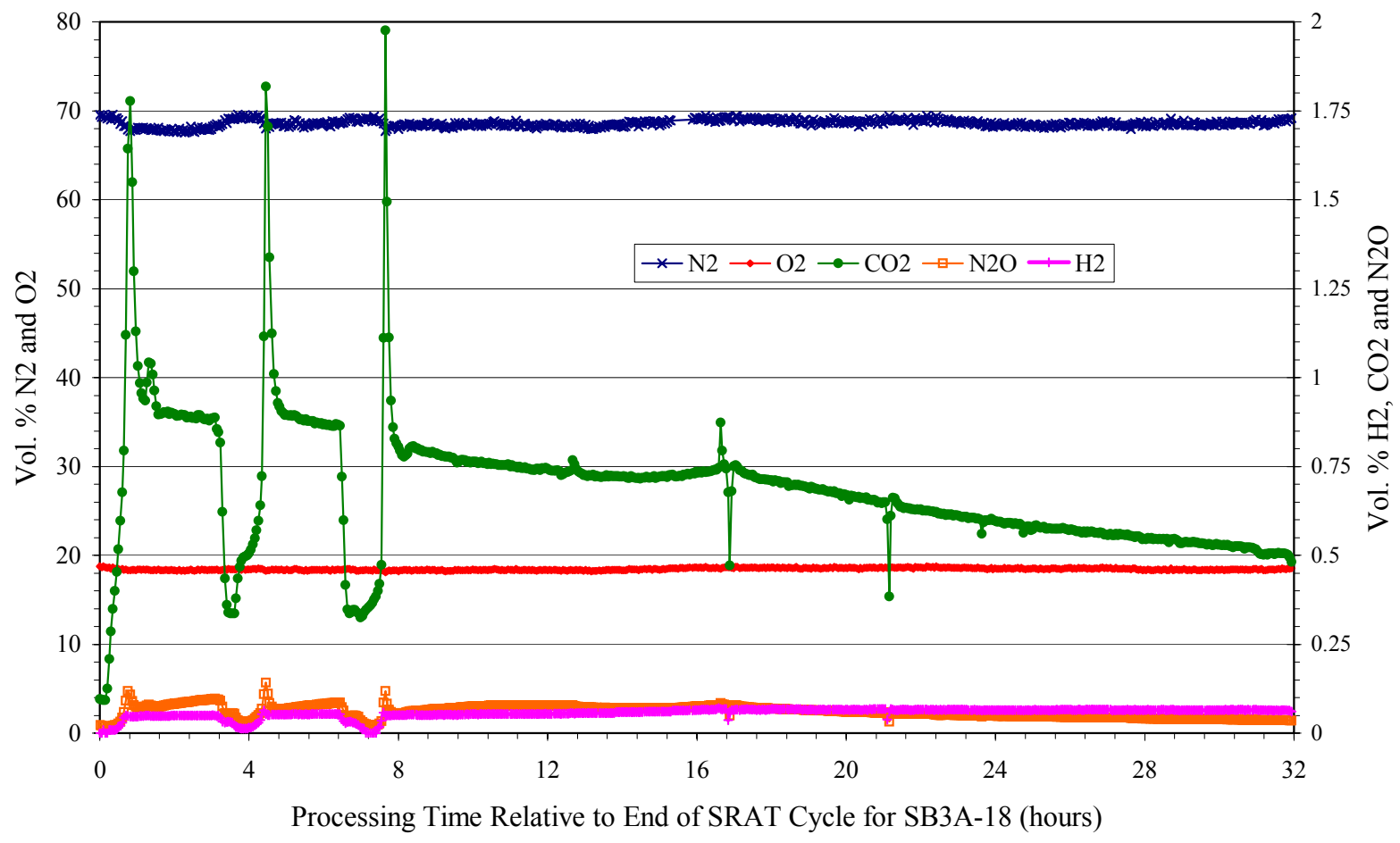

Figure B - 14: SB3A-19 SME Cycle GC Data

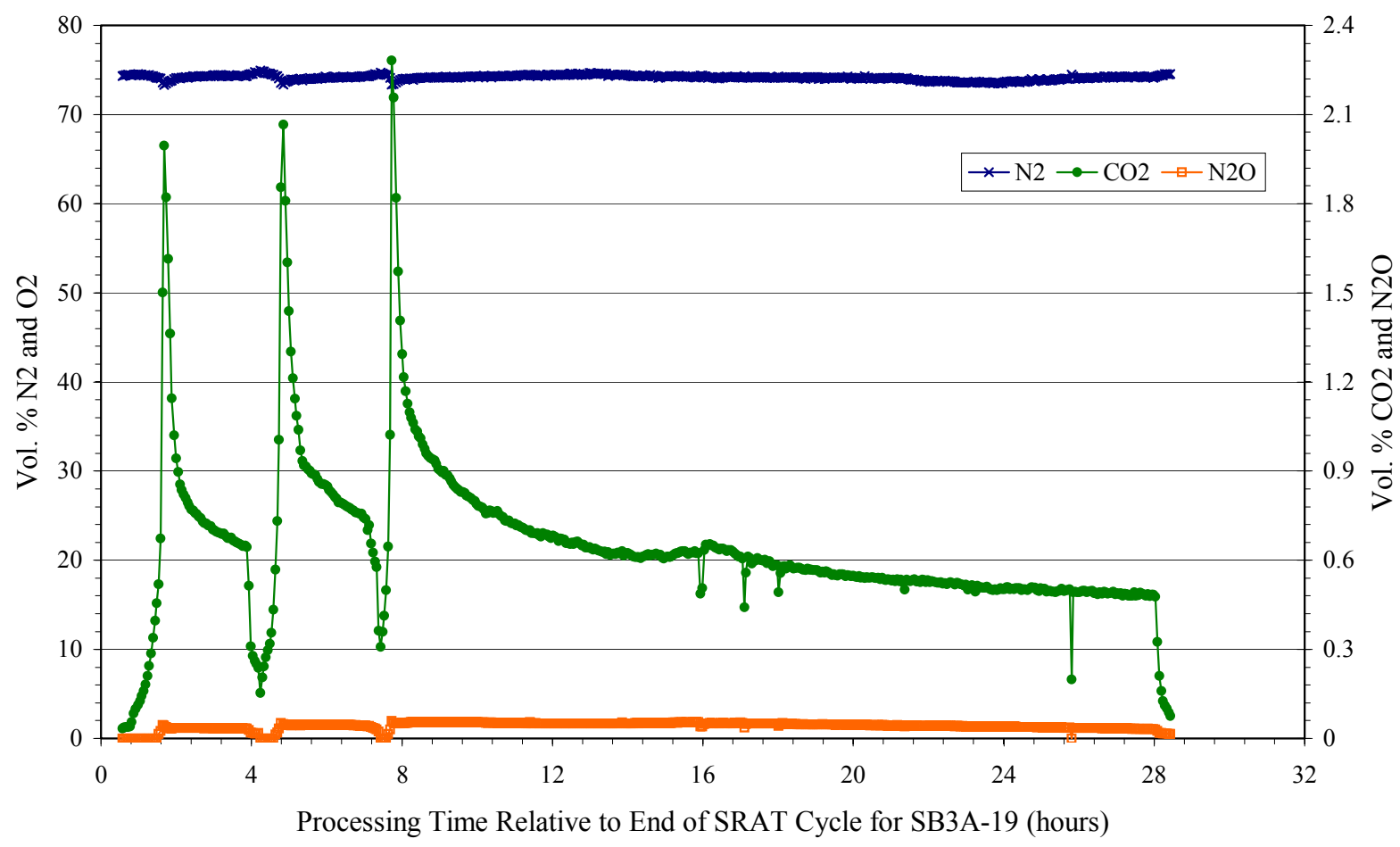


Revision 0

Figure B - 15: SB3A-20 SME Cycle GC Data

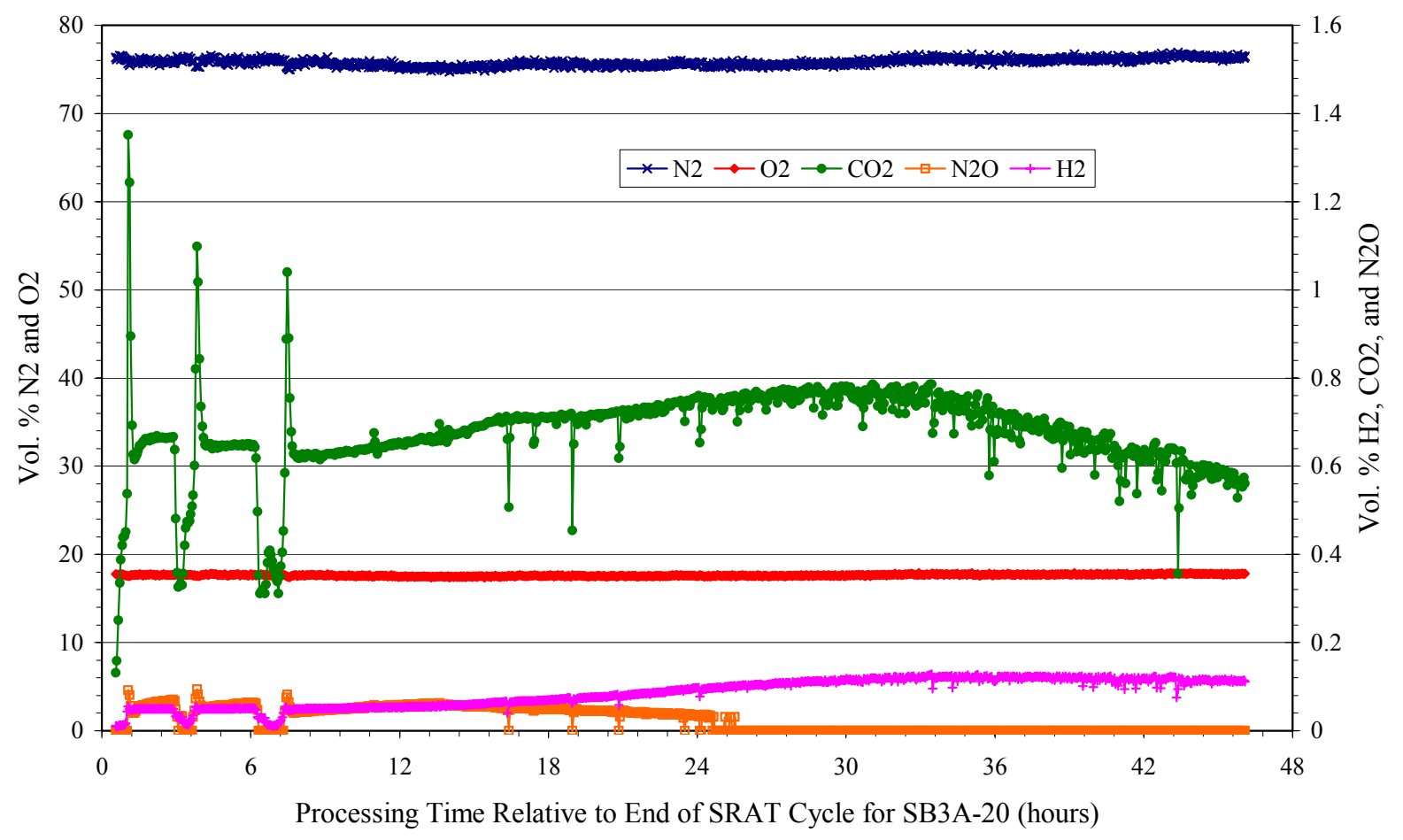

